\title{
Efficacy of 904 NM laser therapy in acute lateral ankle sprains
}

Citation for published version (APA):

de Bie, R. A. (1998). Efficacy of 904 NM laser therapy in acute lateral ankle sprains. [Doctoral Thesis, Maastricht University]. Universiteit Maastricht. https://doi.org/10.26481/dis.19980403rb

Document status and date:

Published: 01/01/1998

DOI:

10.26481/dis.19980403rb

Document Version:

Publisher's PDF, also known as Version of record

\section{Please check the document version of this publication:}

- A submitted manuscript is the version of the article upon submission and before peer-review. There can be important differences between the submitted version and the official published version of record.

People interested in the research are advised to contact the author for the final version of the publication, or visit the DOI to the publisher's website.

- The final author version and the galley proof are versions of the publication after peer review.

- The final published version features the final layout of the paper including the volume, issue and page numbers.

Link to publication

\footnotetext{
General rights rights.

- You may freely distribute the URL identifying the publication in the public portal. please follow below link for the End User Agreement:

www.umlib.nl/taverne-license

Take down policy

If you believe that this document breaches copyright please contact us at:

repository@maastrichtuniversity.nl

providing details and we will investigate your claim.
}

Copyright and moral rights for the publications made accessible in the public portal are retained by the authors and/or other copyright owners and it is a condition of accessing publications that users recognise and abide by the legal requirements associated with these

- Users may download and print one copy of any publication from the public portal for the purpose of private study or research.

- You may not further distribute the material or use it for any profit-making activity or commercial gain

If the publication is distributed under the terms of Article $25 \mathrm{fa}$ of the Dutch Copyright Act, indicated by the "Taverne" license above, 
EFFICACY OF 904 NM LASER THERAPY IN ACUTE LATERAL ANKLE SPRAINS 
In de kosten van dit proefschrift werd bijgedragen door:

Koninklijk Nederlands Genootschap voor Fysiotherapie NEA International b.v.

Uniphy b.v.

6 De Bie, Robert Adriaan

Efficacy of $904 \mathrm{~nm}$ laser therapy in acute lateral

ankle sprains / Robert Adriaan de Bie. - [S.L.:s.n.]

Thesis Maastricht University. - With summary in Dutch.

ISBN 90-74130-23-2

NUGI 751

Subject headings: laser therapy - acute lateral ankle sprains - RCT - prognosis - review

Lay-out: Cobie Martens, Epidemiology UM, Maastricht

Cover: Rob de Bie | Unigraphic

Production: Unigraphic | University Pers Maastricht 


\section{EFFICACY OF 904 NM LASER THERAPY IN ACUTE LATERAL ANKLE SPRAINS}

\section{PROEFSCHRIFT}

ter verkrijging van de graad van doctor aan de Universiteit Maastricht

op gezag van de Rector Magnificus, Prof. dr. A.C. Nieuwenhuijzen Kruseman volgens het besluit van het College van Decanen, in het openbaar te verdedigen op vrijdag 3 april 1998

om 14.00 uur 
Promotores:

Prof. dr. PG Knipschild

Prof. dr. G Kootstra

Co-promotores:

Dr. ir. HCW de Vet

Dr. FAJM van den Wildenberg

Beoordelingscommissie: Prof. dr. JA Knottnerus (voorzitter)

Prof. dr. LM Bouter (Vrije Universiteit Amsterdam)

Prof. dr. D Newman (Kings College London)

Prof. dr. A Huson

Prof. dr. JWIL Stapert 
1. Introduction

2. Efficacy of conservative interventions in the treatment of acute lateral ankle sprains: a systematic review

3. Efficacy of $904 \mathrm{~nm}$ laser therapy in musculloskeletal disorders:

a systematic review

4 The prognosis of ankle sprains

$5 \quad$ Efficacy of laser therapy in ankle sprains: design of a randomised clinical trial

6 Efficacy of low level laser therapy in ankle sprains: short term results of a randomised clinical trial

7 Efficacy of low level laser therapy in ankle sprains: one year results of a randomised clinical trial.

8 General discussion

Summary

Nederlandse samenvatting

Dankwoord

Authors 
Opgedragen aan Hannerieke: "Light and joy of my life" 
One of the highlights of living in the countryside, apart from enjoying the good life and the tranquillity, is catching sheep that have run away or that need to be moved to another part of the meadow. It invokes hillarious scenes with all collected neighbours trampling around like madmen, desperately trying to herd the sheep to their new location. Lack of co-ordination on behalf of the herdsmen and stubbornness of the sheep often results in both sides milling around for hours. But in the end we mostly succeed in our goal. One night, after another sheep hunt, one of my neighbours, a retired engineer, was so elated that he jumped over the fence and sprained his ankle and started calling for help: For some reason everyone pointed at me, saying; "He's the one doing something with ankles at the university, so ask him what to do."

My neighbour looked at me suspiciously and asked; "Do you really know something about ankles?" "No", I said jokingly, "but I'm going to help you anyway. Let's see if you can manage to walk" I continued.

"Why?"

"So we can get back to our shed and I can do some first aid, that's why."

My neighbour now made some serious efforts of standing upright, and with some grunts and curses he managed to do so.

"It doesn"t seem too bad" I said to encourage him, while he stumbled back to the shed.

"I don't agree" he said. "It hurts like hell, and it is starting to swell enormously."

When we had reached our shed I urged my neighbour to sit down: "Take your shoe off, and we'll put your foot under the running tap to cool it."

"Ah, that feels good" he said "but what is it good for?"

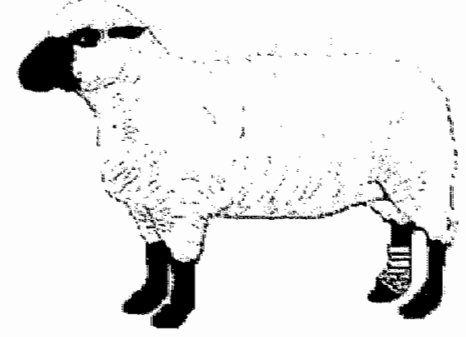

"This is what you could call first aid in ankle sprains. It's called RICE, ${ }^{1,2}$ meaning rest, ice, compression and elevation. Since we don"t have any ice available, 10 minutes under the running tap should do just as well. After that I'll put an elastic wrapping around your ankle and you go home where you put your foot up and take it easy for a day or two."

"I'll be bored to death" he complained. "And although you think it's not serious I want to be sure. So can you take me to the hospital where the doctors can take some $\mathrm{X}$-rays and tell me how bad it is?"

"Sure, but I don't know if the X-ray is telling you anything else than that the ankle isn't brow ken..$^{3^{n}}$

"Okay, but what about all those other new imaging techniques. Surely they can tell me how serious it is and how long this is going to take?" he wondered.

"Well, I'm not so optimistic. Routine stress tests and arthrography have a low reproducibility and do not correlate well with complaints and objective findings, ${ }^{4,5}$ Other diagnostic imaging techniques such as CTscan or ultrasonography are very hard to interpret and Magnetic Resonance Imaging is way too expensive. Besides, there is this underlying idea in all these diagnostic techniques that the extent of the tissue damage 
reflects the severity of the injury; you could question whether this is correct. Besides, some people make a lot of noise when in pain, but the amount of noise doesn't reflect the amount of pain. And for prognosis, well, most doctors just tell you to go home and wait and see."

"So, you're telling me there's no way to inform me how serious it is?" he asked incredulously.

"Yep" I replied.

"I don't like it. And what about this new laser therapy? My cousin is a physiotherapist and has bought a new laser apparatus the other week. He says it is very good at healing sports injuries such as ankle sprains."

"Well", I said, trying to distract my neighbour from his painful foot; "actually, since the 1980 s laser therapy is being used in physiotherapy. Laser therapy in a physiotherapeutic setting is defined by an average power output with a maximum of $50 \mathrm{~mW}$ per square centimetre. ${ }^{6,7}$ So, it's a very low dose laser. Already in 1987 we performed a pilot study about the efficacy of $780 \mathrm{~nm}$ laser therapy on ankle sprains. We then found a $23 \%$ difference in pain reduction within five days in favour of the laser group compared to placebo. Yet, the findings of our study need to be interpreted carefully since we had few patients in the trial."

"I don't understand it" he saild. "It works, and yet you doubt it."

"Because the number of patients is small, it could have been just a chance finding. To be more sure one would need to do a larger trial with at least 50 persons per group."

My neighbour nodded in consent. "Is there really a need for an evaluation in such a rigorous way? Surely, everyone sprains his ankle at sometime during his life, but how serious can it be?"

"Just to give you an idea, in the Netherlands one in every four sports injuries concerns the ankle, while in hospitals four out of 1000 Dutch people are treated for ankle sprains every year. Ankle sprain injuries are responsible for 10 to $15 \%$ of all absenteeism from work, and the average duration of absenteeism is about 7.3 days. Some $20 \%$ of all ankle sprain injuries lead to chronic instability. Medical costs, expenses on sick leave and (semi)-permanent invalidity are high. ${ }^{10}$ Thus, finding new or better therapies for treating ankle sprains in a cost-effective way might be very relevant.

And another thing comes up as well. We studied the literature to gain more insight into the efficacy of laser therapy in musculoskeletal disorders. We performed two systematic reviews. These early reviews, done in 1990 on 35 randomised clinical trials, ${ }^{6,7}$ concluded that laser therapy for musculoskeletal disorders seems promising, when compared to placebo laser therapy. In rheumatic diseases and post traumatic injuries randomised clinical trials showed a swift pain reduction and a quicker functional recovery. However, trials of LT in the treatment of soft tissue injuries, like your ankle, gave conflicting results. And besides, the quality of the research in those trials was not very good. Moreover, there is also a lot of uncertainty what dose is the most adequate."

"And what about other therapies for ankle sprains?"

"Again, I don't know" I admitted lamely. "They use taping nowadays, since they believe it's better than a plaster cast, ${ }^{12-14}$ but all kinds of other therapies are used as well. There"s. hardly any evidence on the efficacy of these therapies."

"My faith in medical science has gone down the drain" my neighbour said. "You don't know my prognosis, you don't know if laser therapy works, and even worse, the quality of 
research in this area is no good."

"Cheer up" I said. "I have just started my PhD thesis investigating these questions of yours, and I'll let you know the answers in a few years."

"Nice going" my neighbour remarked sourly. "You don't really expect me to wait a few years with my ankle until you know the answers, do you?"

"No, we're going to get you to the hospital right now."

\section{SONGE VEARS E. TER R.}

"Hi neighbour."

"What's up son?"

"I'm bringing you some answers to your questions."

"Oh, but I already know what to do about white fly on my cabbage leaves...."

"No, no" I said "It's about your ankle."

"What about my ankle" he said. "It's fine."

"No, I mean the questions you had a couple of years back, when you sprained it."

"Ah, so, err..." He seemed confused. "Eh, what did I ask, again?"

"You wanted to know about the best therapy for sprained ankles, the prognosis of sprained ankles and whether laser therapy was any good."

"I did?"

"Yes, and I have the answers right here" and I handed him my thesis.

"This is a book" he said.

"I know, and it systematically describes everything you wanted to know. After the introduction, which is chapter 1 , chapter 2 presents a systematic review on the efficacy of physiotherapy interventions in acute lateral ankle sprains. It describes 81 studies that investigated the effects of physiotherapy interventions versus other interventions or placebo interventions, in subjects with acute lateral ankle sprains. Of these, 44 fulfilled our entry criteria, and were assessed on methodological criteria.

Chapter 3 describes a systematic review on the efficacy of $904 \mathrm{~nm}$ low level laser therapy in musculoskeletal disorders. We found 25 studies that investigated the effects of $904 \mathrm{~mm}$ laser therapy versus placebo or another intervention, in subjects with a condition for which LT was thought useful. Of these, 21 fulfilled our entry criteria, and were assessed blindly on methodological criteria.

In chapter 4 we write about the prognosis of ankle sprains. We developed a new tool for predicting the severity of ankle sprains just after injury. Since hard data obtained by diagnostic imaging techniques are still imperfect ${ }^{3,4}$ we decided to use data from history taking and signs and symptoms that are part of the intake routine. During a three month period data were collected of 35 patients with lateral ankle sprains who visited the first aid department of the University Hospital Maastricht. Assessments took place at intake and at two and four weeks after injury. From these data we tried to learn about the best predictors for fast recovery."

"I'm speechless" my neighbour said. "But what about the laser therapy?"

"In chapters 5 to 7 we describe the design of the trial and the putative biological mechanisms of laser therapy, as well as, the short and the long term results of a randomised, double blind, clinical trial, in which dosimetric questions are addressed as well."

"I see. And what is your opinion about all this research on ankle sprains?"

"Well, chapter 8 discusses the relevance of our research in the ankle sprain business."

"But tell me, is this thesis not far too complicated for me to read?" 
No, there is also an extended summary of it all in Dutch."

"You seem to have an answer to everything." "Well, only to acute lateral ankle sprains: So, happy reading! And, you know what, I'll bring you a bottle of home made wine as well:"

"Now that's something" he said. "Perhaps science isn't so bad after all!"

\section{RWHEKENGE}

1. Cote JD, Prentice WE, Hooker DN, Shields EW. Comparison of three treatment procedures for minimalizing ankle sprain swelling. Physical Therapy $1988 ; 68: 1072-6$.

2. Wilkerson $G B$, Horn Kingery $H M$. Treatment of the inversion ankle sprain: comparison of different modes of compression and cryotherapy. JOSPT 1993; 17: 240-6.

3. Moppes FI van, Hoogenband $\mathrm{CR}$ van den. Diagnostic and therapeutic aspects of inversion trauma of the ankle joint. $\mathrm{PhD}$ Dissertation. Maastricht, 1982.

4. Jongen SJM, Pot $\mathbf{J H}$, Dunki Jacobs PB. De behandeling van de verzwikte enkel (The treatment of the sprained ankle) Geneeskunde en Sport 1992; 25: 98-101.

5. Ent FWC van der. Letsels van het laterale enkelbandapparaat (Lateral ankle joint ligament injwries) Nederilands Tijdschrift voor Fysiotherapie 1991; 96: 121-3.
6. Beckerman $\mathrm{H}_{3}$ Bie RA de, Bouter $\mathrm{LM}$ et all. The efficacy of laser therapy for musculoskeletal and skin disorders: a criterium based meta analy"sis of randomized climical trials. Physical Therapy 1992: 72: 483-91.

7. Bie RA de, Beckerman H, Cuyper HJ de, Bouter LM. Dosis en effekt van lasertherapie; overzicht wan de beschikbare therapeutische experimenten. (Dosis and effect of lasertherapy) Nederlands Tijdschrift waor Fysiotherapie 1991; 101: 196202.

8. Bie de RA, Steenbruggen RA, Bouter LM. Effekt van lasertherapie op inversie-traumata van de enkel. (Efficacy of laser therapy in acute lateral ankle sprains) Nederlands Tijdschrift voor Fysiotherapie 1988; 95: 108-12.

9. Bol E, Schmickli SL, Backx FJG., wan Mechelen W. Sportblessures onder de knie: programmering van toekomstig onderzoek. (Control over sports injuries; planning future research) NISGZ, 1991.

10. Epidemiologie van sport en gezondheid (Epidemiology of sports and health) Bol $\mathrm{E}_{\mathrm{k}} \mathrm{Backx}$ FJG, Mechelen W van. Red. De Tijdstroom, Utrecht, 1997.

11. Cetti $\mathrm{R}$, Christensen $\mathrm{SE}$, Corfitzen MT. Ruptured fibular ankle ligament: plaster or pliton brace? Brit I Sports Med 1984;18(2):104-9.

12. Caro D, Craft IL, Howells JB, Shaw PC. Diagnosis and treatment of injury of lateral liganent of the ankle joint. The Lancet 1964; 720-3. 


\author{
Robert A de Bie, MA, PT \\ Arianne P Verhagen, M.Sc, PT \\ Anton $\mathrm{F}$ Lenssen, $\mathrm{PT}^{2}$ \\ Henrica CW de Vet, $\mathrm{PhD}^{1}$ \\ Frans AJM van den Wildenberg, $\mathrm{MD}, \mathrm{PhD}^{3}$ \\ Gauke Kootstra, $\mathrm{PhD}, \mathrm{MD}^{3}$ \\ Paul G Knipschild, MD, $\mathrm{PhD}^{1}$

\footnotetext{
${ }^{1}$ Department of Epidemiology, Maastricht University

${ }^{3}$ Department of General Surgery, University Hospital of Maastricht
} \\ ${ }^{2}$ Department of Physiotherapy , Uniwersity Hospital of Maastricht
}

\title{
ABstrikter
}

Objective: This systematic review summarises the efficacy of conservative interventions in acute lateral ankle sprains.

Method: We performed computer aided searches of databases and of bibliographic indexes. Furthermore, we checked congress reports, reviews and relevant citations. Subsequently, all retrieved empirical studies were scored on methodological quality and effect sizes were caloulated for pain, swelling and days of sick leave.

Results: We found 81 studies that investigated the effects of physiotherapy interventions versus other interventions or placebo interventions, in subjects with acute lateral ankle sprains. Of these, 44 fulfilled our entry criteria.

Study quality ranged from poor ( 9 points) to rather good ( 70 points). Only two studies scored more than 60 points (both on pulsed shortwave therapy) and they showed no effect. Tape was found to be superior over other types of treatment, in effect shortening the duration of sick-leave, while plaster of Paris treatment seemed to prolong sick-leave. Placebo therapies delivered no positive results.

Further and improved research is needed to shed more light on efficacy of other treatment interventions. 


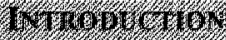

Ankle sprains are one of the most common injuries of the ankle, and are most often reported in relation to sports participation." They relate to the lateral ligament complex of the ankle, and are reported on as sprains, strains, inversion injuries, lateral ankle injuries and lateral ligament injuries.

There is stll much debate about which therapy is most effective in the treatment of ankle sprains. There are many treatment options available, but there is little consensus which treatment is the most efficacious. Many choices regarding therapy seem to be driven by tradition or fashion rather than efficacy.

Adequate initial treatment for ankle sprains is thought to consist of rest, ice, compression and elevation (RICE) ${ }^{2,3}$ while treatment after the initial phase can consist of plaster of Paris, taping, braces or special orthoses, often combined with all kinds of adjunct therapies. In the case where the ankle is being surgically treated, one often chooses for a plaster of Paris approach afterwards.

To shed some light on the efficacy of conservative treatment approaches for ankle sprains, we performed a systematic review to evaluate the effects of the provided therapies on the outcome measures pain, swelling and sick-leave.

\section{Mistition}

Trials on interventions for lateral ankle sprains were identified by Medline and Embase searches (both up to 1996) and by checking the Database of the Cochrane 'Rehabilitation \& Related Therapies Field' at Maastricht University, the Netherlands. Additionally, we checked Current Contents,
Physiotherapy Index, reviews, congress reports and handbooks. Retrieved references were followed-up by citation tracking. Papers published in English, French, German, Dutch, Spanish, Italian, Norwegilan, Swedish and Danish were eligible for inclusion. Languages outside the above mentioned range, as well as abstracts and unpublished studies were not included. The search strategy was derived from the search strategy described by Dickersin ${ }^{4}$ which is now widely being used by Cochrane reviewers. Keywords used to describe the design were: randomised controlled trials, controlled clinical trials, random allocation, double blind, single blind, experiments and evaluation studies. Keywords used to identify the illness were: ankle, sprain, inversion, lateral ankle sprain, lateral ankle ligament injury and strain. Keywords to identify the interventions were: therapy, exercise, rehabilitation, bracing, taping, cast, plaster of Paris, orthosis and all physical therapy madalities known to us ((pulsed) ultrasound therapy, laser therapy, (pulsed) short wave therapy, electro therapy, thermo therapy and cryo therapy).

The selected studies had to fulfil the following criteria for inclusion in the review. The subjects in the study had to suffer from a lateral ankle sprain. The therapy should consist of conservative treatment approaches and had to be contrasted with placebo, no treatment, physiotherapeutical or other interventions, while studies comparing various surgical techniques were excluded. The study design had to be a randomised clinical trial.

The papers eligible for reviewing were given to two reviewers (APV and AFL) who independently assessed the quality of all retrieved studies. In a consensus meeting they tried to reach agreement on items on which 
they had different opinions. If consensus could not be reached, a third reviewer (RAB) made the final decision.

Table 1 shows the criteria for assessing the methodological quality of the trials. The list was originally designed by Ter Riet et al. ${ }^{5}$, and modified over the years by Koes et al. ${ }^{6}$, De Vet et al. ${ }^{7}$ and Assendelft et al. ${ }^{8}$. It is based on generally accepted principles of intervention research: ${ }^{910}$ The criteria list was adapted for anklie sprains with respect to the intervention and relevant outcome measures. Studies could earn points for methodological quality in five categories. These categories were study population, interventions, blinding, outcome, and data presentation and analysis. A maximum score of 100 points could be obtained.

Table 1: Criteria for assessing methodological quality in randomised clinical trials of low level laser therapy.

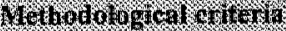

\section{Study population (total points=48)}

$\begin{array}{llr}\text { A } & \text { Homogeneity } & 4 \\ \text { B1 } & \text { Randomisation procedure mentioned } & 10 \\ \text { B2 } & \text { Concealed method of randomisation } & 10 \\ \text { C } & \text { Comparability of relevant baseline characteristics } & 6 \\ \text { D } & \text { Numbers of patients } & 8 \\ \text { E } & \text { Dropouts described for each study group separately } & 7 \\ \text { F } & \text { Loss to follow up not leading to bias } & 3\end{array}$

Intervention (total points=12)

$\mathrm{G} \quad$ Intervention adequately described and performed

H Co-interventions avoided or equal in study groups

Blinding (total points $=21$ )

$1 \quad$ Patients blinded

J Therapist blinded

$\mathrm{K} \quad$ Observer blinded

Outcome (total points=12)

L Adequate outcome measures $\quad 5$

M Adequate follow up period 5

N Description of side effects 2

\section{Data presentation and analysis (total $=7$ )}

O Mean or frequencies of mast important outcome measures presented for each group 1

$\mathrm{P} \quad$ Intention to treat analysis 3

Q Adequate correction for baseline differences or drop outs

To synthesise the data we pooled the data using a random effects model. "All outcomes are reported as effect sizes with $99 \%$ confidence intervals. Effect sizes allow comparisons among studies that address the same research hypotheses but use somewhat different manipulations and/or outcome measures. The thus obtained effects are measured in terms of their own standard deviations. Effect sizes were calculated by 
using Cohen's $d$ or Hedges"s g. ${ }^{11,12}$ Tests for heterogeneity in pooled estimates were done by using chi-square statistics."

\section{7.}

81 Trial reports were identified that use some form of randomisation and study various interventions for the treatment of ankle sprains and contrast them with a different intervention, placebo therapy or no therapy. Of these, 27 were excluded from further reviewing (references can be obtained from the authors): 10 studies use medication versus placebo, 8 describe preventive effects, 6 study biomechanical aspects of ankle orthosis and braces, 1 incorporates multiple foot injuries, 1 studies healthy subjects and 1 reports only 2-

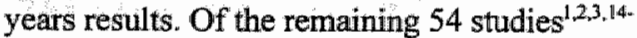
${ }^{38}, 4$ were reported more than once ${ }^{19,24,27,30}$ and two 3 or 5 times. ${ }^{54,58}$ of duplicate trials the most complete descriptions were used in this review.

The methodological characteristics of 44 trials are presented in Table 2. They are ranked according to their methodological score.

The methodological score ranged from 9 to 70 points. Only 2 studies scored more than 60 points, implying the methodological inadequacy of $95 \%$ of the material. There was no apparent relationship between the year of publication and the methodological quality. The average methodological score for negative trials was 35 points (SD 14), and the average methodological score for positive trials was 29 points (SD 10). The blanks in the table give insight in methodological aspects of the reviewed trials that were not reported.
Onlly three studies reported to have used a concealed randomisation method (item B). ${ }^{18,36,42}$ Many studies were hampered by large numbers of drop outs and losses-tofollow up (items $E$ and F). A few studies even lost over $50 \%$ of the population during follow up. ${ }^{21,22,33}$ Blinding of patient, therapist or observer occurred seldom (items I, J, K). Side-effects were scarcely reported upon (item N). Finally, presentation of data and analyses was inadequate in many cases (items $\mathbf{P}$ and $\mathbf{Q}$ ).

Table 3 gives a short description of the study design, participants, interventions and outcome measures for all studies. The studies are ranked alphabetically. The 44 reviewed trials contained in total 4646 patients with ankle sprains. In total 35 interventions were studied, among which 5 larger subgroups could be detected. 13 Trials reported on plaster of Paris (cast) versus another intervention. Tape was studied in 19 trials, whereas a form of bracing or bandage was studied in 10 and 7 trials respectively. 11 Studies used placebo therapy as a contrast to another intervention, that mostly consisted of a physical therapy modality such as laser, ultirasound or pulsed shortwave therapy.

The column 'participants' describes the number of participants per group, and provides demographic data. The column interventions gives insight into the specific treatment modalities that were used. The column on outcome measures shows the timing of measurement. The last column (notes) provides additional data on drop outs and number of patients that were lost during the intervention period or during follow up as well as other remarks. 
Table 2: Methodological scores of the reviewed trials

\begin{tabular}{|c|c|c|c|c|c|c|c|c|c|c|c|c|c|c|c|c|c|c|c|}
\hline Whor & x & x & 2. & 6. & 8 & e & in & \% & 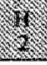 & . & , & 1 & 1) & 椾 & (x) & s. & , & ( & (1) \\
\hline barket & 85 & 4 & 20 & 2 & 6 & 2 & & 10 & 2 & 7 & 7 & & 4 & 5 & & 1 & & 50 & negaive \\
\hline merpill & 88 & 4 & 20 & & 8 & 6 & 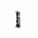 & 10 & 2 & & 3 & & 3 & 5 & & 1 & & 63 & negative \\
\hline zeogens & 95 & 4 & 10 & 4 & 4 & $\$$ & & 6 & 2 & & & & 5 & 5 & 2 & 1 & & 48 & negutiwo \\
\hline olhara & 92 & 4 & 10 & 6 & 4 & 7 & & 6 & 2 & & & & 4 & & & & 3 & 46 & positive \\
\hline bee & 88 & 4 & & & 6 & 7 & & 10 & 2 & 3 & 3 & 3 & 2 & & & 1 & 3 & 44 & positive \\
\hline Ktein & 91 & 2 & 20 & 2 & 4 & & & 6 & & & & & 1 & 5 & & d & & 41 & negative \\
\hline sloan & 89 & 4 & 10 & 4 & 6 & & & 6 & 2 & & & 3 & 5 & & & & & 40 & posulitive \\
\hline pennington & 93 & 4 & & 2 & & 5 & & 10 & 2 & 3 & & 3 & 5 & & & 1 & 3 & 38 & posilive \\
\hline oostendorp & 87 & 4 & & & 4 & 7 & 3 & 6 & & & & 3 & 4 & 5 & & 1 & & 37 & positive \\
\hline wester & 96 & 4 & 10 & 2 & 2 & & & 8 & & & & & 5 & 5 & & 1 & & 37 & positive \\
\hline piasila & 78 & 2 & 10 & 6 & 6 & & & 8 & & & & & 4 & & & 1 & & 37 & posilitive \\
\hline Koniratsen & 91 & 2 & & 2 & 8 & 7 & 2 & 6 & & & & & 2 & 5 & 2 & 1 & & 37 & posilive \\
\hline fohtannes & 93 & 4 & 10 & 4 & 4 & 2 & & 6 & 2 & & & & 1 & & 2 & 1 & & 365 & negative \\
\hline williamson & 86 & 2 & 10 & 4 & 4 & 2 & & 6 & 2 & & & 3 & 1 & & & 1 & & 35 & negative \\
\hline stotece & 92 & 4 & & 4 & 2 & 7 & 3 & 6 & 2 & & & & 1 & 2 & & 1 & 3 & 35 & positive \\
\hline misson & 83 & 4 & & 4 & 2 & 6 & $\|$ & 6 & & & & & 5 & 5 & & 1 & & 34 & negative \\
\hline axelsen & 93 & 4 & 10 & & 6 & 1 & & 10 & & & & & 2 & & & 1 & & 34 & positive \\
\hline brafnock & 95 & 4 & & & & 7 & & 10 & 2 & 3 & & & 1 & 2 & & 1 & 3 & 33 & negative \\
\hline $\mathrm{cett}$ & 84 & 4 & & 4 & & 7 & 3 & 6 & & & & & & 5 & & 1 & 3 & 33 & positive \\
\hline dettori & 94 & 4 & & & 8 & 1 & $\mathbb{1}$ & 6 & & & & 3 & 4 & 5 & & 1 & & 33 & postitive \\
\hline sommer & 93 & 4 & & 2 & 4 & 7 & 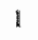 & 6 & & & & & 2 & 5 & & 1 & & 32 & positive \\
\hline $\mathrm{clarr}$ & 91 & 2 & & & 4 & & & 10 & 2 & 3 & 3 & & 2 & 5 & & & & 31 & negative \\
\hline eift & 94 & 4 & & 2 & & & 2 & 10 & 2 & & & & 5 & 5 & & 1 & & 31 & positive \\
\hline hedges & 80 & 4 & & 4 & 8 & & & 6 & & & & & 3 & 5 & & 1 & & 31 & neggative \\
\hline holmer & 91 & 4 & & 6 & 4 & 1 & & 6 & 2 & & & & 5 & 2 & & 1 & & 31 & negative \\
\hline cotee ${ }^{\prime}$ & 88 & 2 & & & 6 & 7 & & 10 & & & & & 1 & & & 1 & 3 & 30 & positive \\
\hline leanderson & 95 & 4 & & 2 & 6 & & & 6 & 2 & & & & 3 & 5 & & 1 & & 29 & positive \\
\hline korkala & 87 & 4 & & 4 & 2 & & & 6 & & & & & 4 & 5 & 2 & 1 & & 28 & mergative \\
\hline mollertarson & 88 & 4 & & 4 & 4 & & 1 & 6 & & & & & 2 & 5 & & 1 & & 27 & positive \\
\hline brakenbury & 83 & 2 & & 6 & 6 & & & 6 & 2 & & & & 4 & & & 1 & & 27 & positive \\
\hline nucinsks & 91 & 2 & & & 2 & 7 & & 8 & 2 & & & & 1 & & & 1 & 3 & 26 & positive \\
\hline michlovise & 88 & & & & 2 & 7 & & 10 & & & & & 3 & & & 1 & 3 & 26 & negative \\
\hline jongen & 92 & 4 & & 4 & 2 & 1 & $\sharp$ & 6 & & & & & 1 & 5 & & 1 & & 25 & negative \\
\hline gronmatk & 80 & & & 2 & & 7 & 3 & 6 & & & & & 1 & 2 & & 1 & 3 & 25 & negative \\
\hline tauvanga & 86 & 4 & & 2 & 8 & & 2 & 6 & 2 & & & & 1 & & & & & 25 & positive \\
\hline alfolksinen & 90 & & & & 6 & & & 8 & & & & & 4 & $s$ & & 1 & & 24 & posilive \\
\hline lellaved & 79 & & & & 2 & 5 & & 10 & 2 & & & & 1 & & & & & 20 & positive \\
\hline zwipp & 92 & & & 2 & 2 & & & 6 & 2 & & & & 1 & 5 & & 1 & & 19 & positive \\
\hline allen & 85 & 4 & & & 4 & & & 6 & & & & & 2 & & & 1 & & 17 & negative \\
\hline wilkerson & 93 & 4 & & & 2 & & & 6 & 2 & & & & 1 & & & 1 & & 16 & negative \\
\hline freenain & 65 & & & & & & & 6 & & & & & 3 & 2 & & & & 14 & posititwe \\
\hline caro & 64 & & & 2 & & & & 6 & 2 & & & & 2 & & & 1 & & 1.3 & posititive \\
\hline mokulown & 77 & & & 2 & & & & 6 & & & & & 1 & & & & & 9 & postive \\
\hline brooks & 81 & 2 & & & & & & 6 & & & & & 1 & & & & & 2 & nosive \\
\hline
\end{tabular}

+ See Table 1 for explanation of categories $A$ to $Q$ 


\section{Table 3 Description of studies and outcomes}

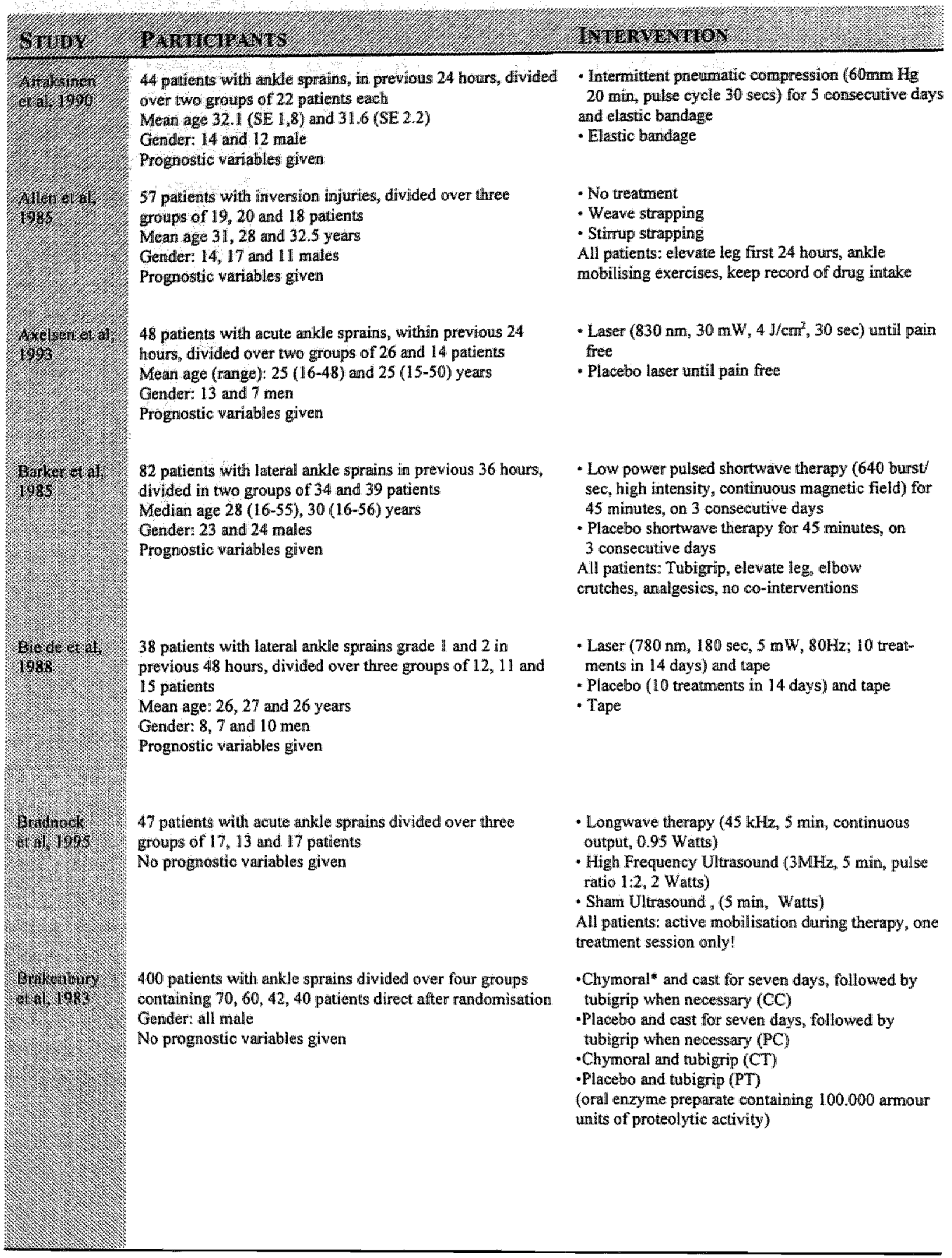


Assessments at intake, 1 and 4 weeks

- Decrease in oedema: at 1 week $72 \mathrm{ml} \mathrm{vs} 29 \mathrm{ml}$, at 4 weeks $104 \mathrm{ml}$ and $85 \mathrm{ml}$

- ROM: $12^{\circ}$ ws $4^{\circ}$ at 1 week, and $20^{\circ}$ vs $16^{\circ}$ at week 4

- Pain relief (VAS): 14 min vs 26 morm at week 1 , and 44 min vs 36 mm at week 4

- Lirnb function (VAS): $30 \mathrm{~mm}$ vs $10 \mathrm{~mm}$ at I week, and $48 \mathrm{~mm}$ vs $34 \mathrm{~mm}$ at 4 weeks

Assessments on intake and at 10 days

- ROM improvernent in \%: No treatment $33.8 \%$, Weave $28.6 \%$, Stirrup $22.1 \%$

- Distance walk in sec.: No treatment 13.6, Weave 12.7, Stirrup 10.9

- Pain (severe/ moderate/ none): No treatmem $3 / 2 / 3$, Weave $0 / 10 / 3$, Stirna $1 / 6 / 5$

- Requiring analgesics: No treatment 7, Weave 9, Stimup 4

Assessments at intake and at 1 week

- Swelling in ml (graph); laser - 1.53 (0.76), placebo-1.5 (1.41)

- Pain free in days (rango)" laser 5 (2-50), placebo 14 (1-20)

- Sick leave in days (range): laser 1.7 (2.34), placebo 5.4 (5.4)

- Analgesic consumption: no data

Assessinents on days $1,2,3,8$ and 15

- ROM (graph): ratio"s on all days $p>0.35$

- Average walking velocity (graph): all days $p>0.35$

- Average length of two steps (graph): all days $p>0.35$

- Foot timing data (graph): all days $p>0.35$, except diay 3, $p^{-28}$

- Symmetry of foot position (graph): all days $p>0.35$, except day 2 and $8 p=0.21$

- Pairi (VAS) (graph); all days $p>0.35$

- Swelling (graph); all days $p>0.35$, except day $2 p=0.21$

Assessments on 5 and 17 days

* Difference in pain during the day compared with baseline; at 5 days: laser $71 \% \%_{3}$ placebo $48 \%$, tape $53 \%$; at 17 days: laser $90 \%$, placebo $78 \%$, tape $91 \%$

- Difference in pain during the night compared with baseline; at 5 days: laser $98 \%$ placebo $76 \%$, tape $60 \%$; at 17 days: laser $97 \%$, placebo $95 \%$, tape $94 \%$

- Hindrance in sports actiwities conpared with baseline at 5 days: laser $8 \%$, placebo $0 \%$, tape $4 \%$, at 17 days: laser $42 \%$, placebe $3.7 \%$, tape $18 \%$

Assessments at intake, after 1 treatment and at 3 days

" Mean stride length improvement ratio (SD). LWT $1.64(26.8 \%)$, HF US $1.19(12.3 \%)$, Sham I. 2 II (12.6\%)

- Whean swing phase duration improvemert (SD): LWT 1.34 (23\%), HF US 1.06 (12.8\%, shan 1.16 (13.2\%)

- Double support duration ratio (seconds) (SD): LWT $0.74(30.3 \%)$, HF US 0.83 (16.9\%), Sham 0.38 (10.9\%)

* Cadence ratio (steps/minute) (SD): LWT 1.17 (18.7\%), HF US 1.04 (12.3\%), Sharn 1.09 (9.3\%)

"Walking speed (metres second) (SD): LWT 2.08 (32.6\%), HF US 1.27 (16.8\%), Sham 1.34 (17.2\%)

Assessunents intake and at 3,7 and 14 days

- Bruising on day 7 (worse, same, better): CC (12/19/39), PC (18/18/24), CT (10/12/20), PT (4/5/31); on day 14: $\mathrm{CC}(3 / 7 / 5)), \mathrm{PC}(7 / 10 / 34), \mathrm{CT}(2 / 6 / 28), \mathrm{PT}(2 / 2 / 33)$

- Oedema on day 7 (worse, same better): CC (5/22/49), PC (6/20/45), CT (3/16/25), PT (1/9/42); on dny 14 : $\mathrm{CC}(3 / 2 / 70), \mathrm{PC}(1 / 6 / 64), \mathrm{CT}(1 / 4 / 38), \mathrm{PT}(0 / 3 / 49)$

- Changes from initial in plantar flexion; on day 3 (better/same/worse); CT (16/13/17), PT (29/10/14) (CC and PC missing); on day 7: CC (39/14/24), PC (37/7/30), CT (20/6/20), PT (31/8/14); on day 14: CC (5:5/6/16i), PC $(45 / 8 / 21)$, CT $(24 / 9 / 14), \mathrm{PT}(37 / 19 / 7)$

- Changes in power of dorsal flexion (SEM) on day 7:CC 17.2 (2.6), PC 10.8. (3,3), CT 23.2 (5.2), PT 15 (3.9): on day 14: CC 29.8 (3), PC 30.8 (4), CT 34.3 (5.3), PT 31.5 (4)

- Changes in degrees of dorsiflexion (SEM) on day $7: \mathrm{CC} 3.7(2.3)$, PC $3.1(1.7), \mathrm{CT} 7.3(3.8), \mathrm{PT} 6.3(3.2)$;

on day $14:$ CC $10.4(2.2)$, PC 9.8 (2.8), CT 9.5 (3.9), PT $13.5(3.9)$

- Olobal response at 14 days (nome/moderavelcomplete): CC $(0 / 40 / 37), \mathrm{PC}(0 / 47 / 25), \mathrm{CT}(0 / 17 / 29), \mathrm{PT}(0 / 2 \mathrm{U} / 33)$

- Mean time aff work in days (SEM); CC $16.3(0.8), \mathrm{PC} 16.2(0.8), \mathrm{CT} 11.6(1.1)$, PT $11.2(1.1)$

Otily 1

treatrient given

$47 \%$ drop outls $33 \%$ 106 10 follow up no antertion to treed andialyis 


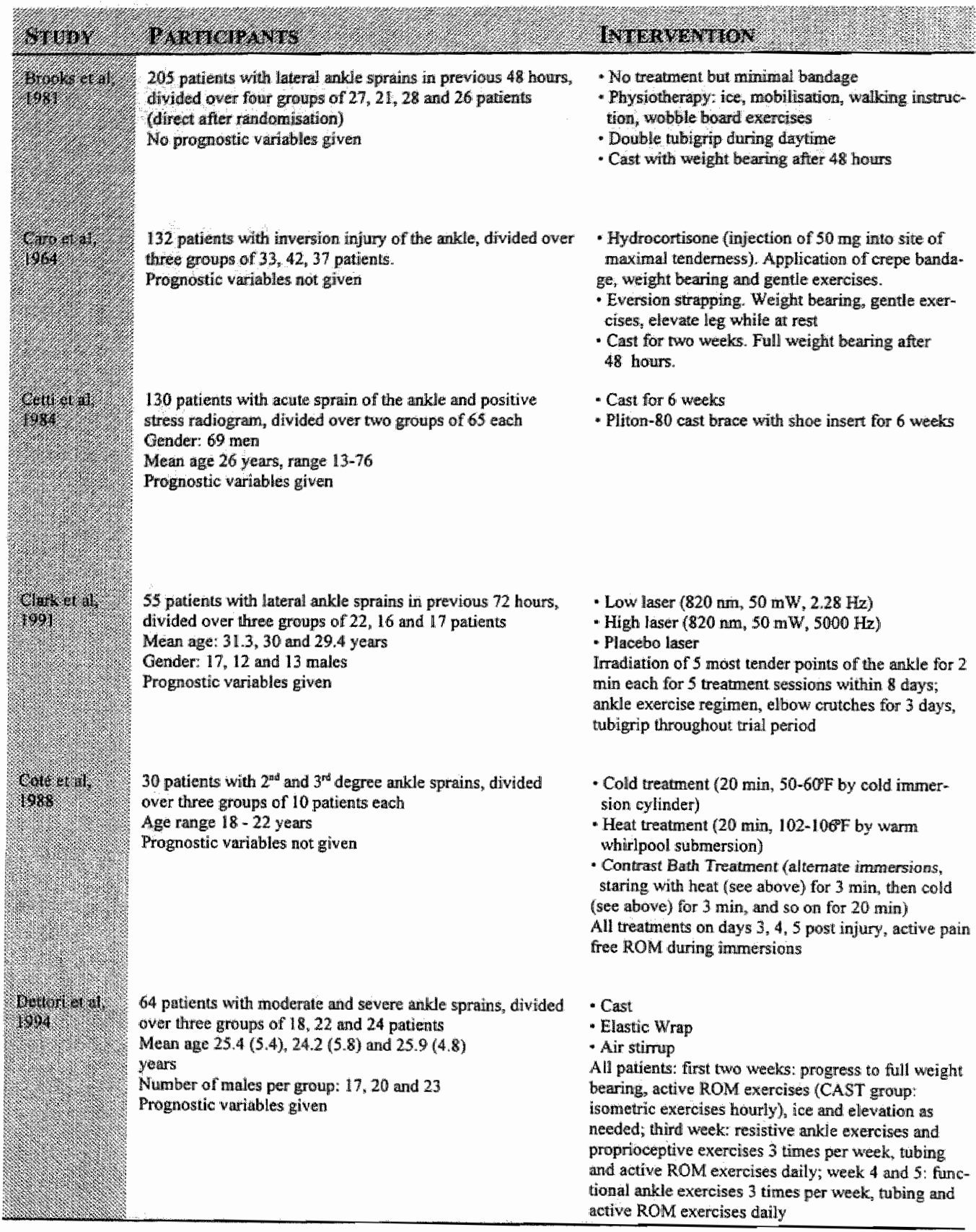


Assessment after 48 hours and weekly

- Clinicall soore (15 points max):

- First visit: no treatment 62 , physio 6.5 , tubignip 7.1 , cast 7.1

- Second visit: no treatment 28 , physio 4.9 , tubigrip 5.1 , cast 62

50 W loss to

- Third visit no treatment 1.0, physio 1.2 , tubigrip 1.0 , cast 1.6

follow up

now intention 10

- Fourth wisit: no treatment 2.0 , physio 0.4 , tubigrip 0.5 , cast 0.8

- Fifth visit: no treatment 0.2 , physio 0.5 , wbignip 1.0 , cast (missing)

- Tinse to cure: hydrocortisone 14.4 (war 66.8) days, eversion strapping 20 (var 121.2 days) and cast 25.3 (var 68.44) days

- Frequency of residual symptoms after three months

$15.2 \%$ loss to follow up no intention to treat analysis

Assessments at 2 and 6 months

- Sports activity (in 80 sport performers) after 6 months (same/lesser/stopped); Cast (34/4/2), Pliton (38/2/0)

24. weeks table

- Sick leave by severity of employment;

- heavy; cast 43.1 days, Pliton 13 days

- fairly heavy; cast 44.2 days, Pliton 13 days

rosotdusal symptomis

- light; 31.5 days, Pliton 10 days

- overall meen; cast 37.5 (range 2-63) days, Pliton 12.2 (range 0-44) days

- Clinical assessment (excellent/good/poor); cast (37/21/7), Pliton (47/14/4)

- Treatment assessment (excellent/good/poor); cast (43/15/7), Pliton (56/7/2)

- Assessments on visits 1, 3, 5, 6 and 15

- Swelling (anova $\mathrm{p}=0.35$ )

- $R O M$ (anova $p=0.319$ )

- Pain (anova $\mathrm{p}=0.347$ )

- Contact time (anova $p=0.664$ )

- Step length (anova p=0.84)

- Velocity (anova $p=0.139$ ) unclear

Assessments at 2, and 5 weekis

- Median number of dayss before re-uptake of work: Cast 32.4 days Elastic wrap 29.6 days and Air Stimup 29.4 days

- Decrease in swelling; at 2 weeks: Cast $2.6 \%$, Wrap $4.5 \%$, Air Stimup $4.8 \%$; at 4 weeks: Cast $5.6 \%$, Wrap $5,5 \%$,

Air Stimup $6.5 \%$ (estimated from graph)

- Mean functional pain index diffenence (0-4); at 2 weeks: Cast 0.7 points, Wrap 1.9 points, Air Stirup 1.8 points; al

5 weeks: Cast 2.8 points, Wrap 2.9 points, Air Stirrup 2.7 points (estimated from graph)

- ROM: $28 \%$ of the cases for each group missing and data unclear

"Active ROM: unclear 


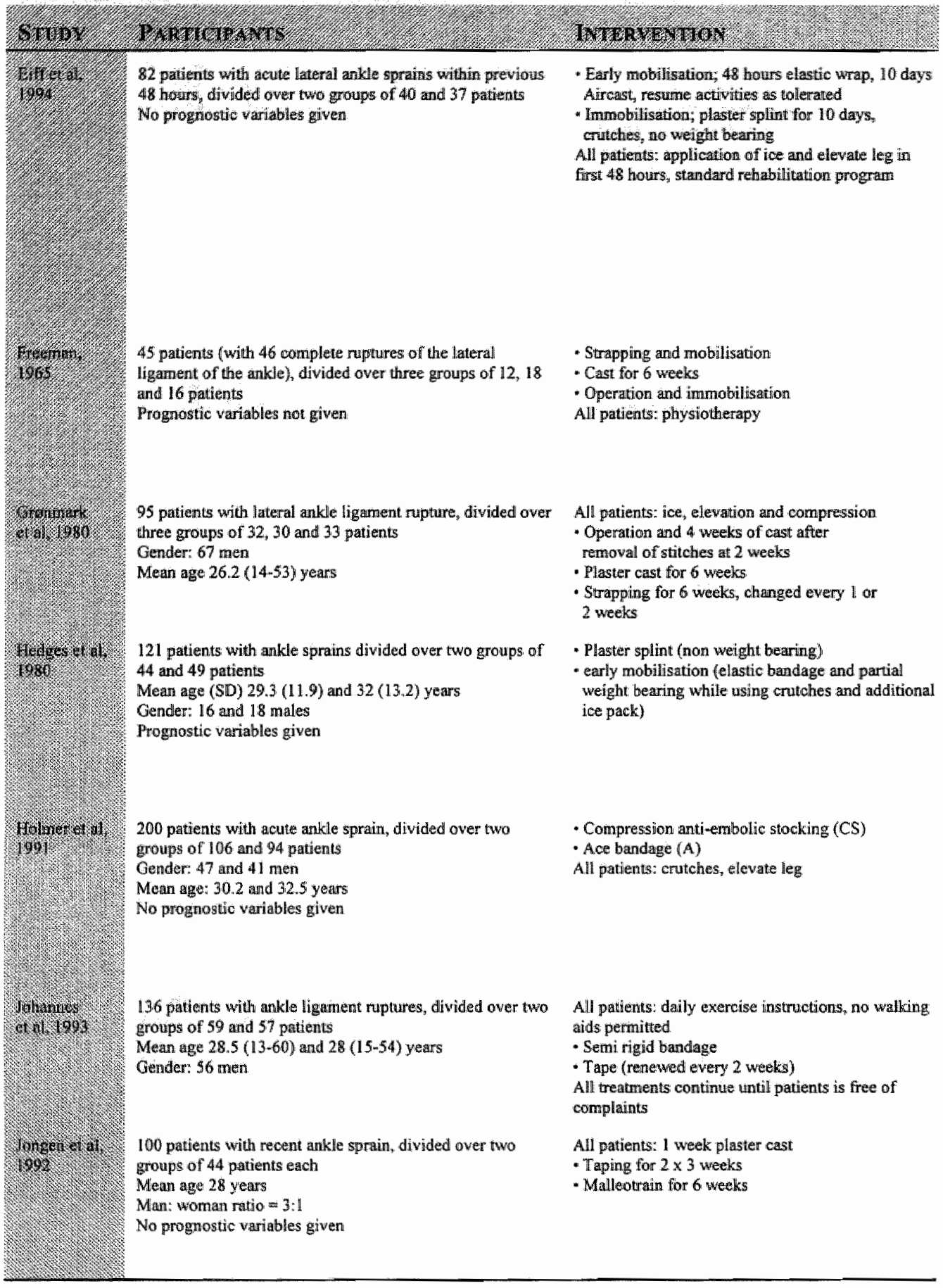


Assessments at 3 and 10 days, 3 and 6 weels, and 3,6 and 12 months

- Residual pain at 10 days; Mobilised (M) $81 \%$ Immobilised (n) 78\%; 3 weeks, M 57\%, $187 \%$ (P<0.05);

6 weeks M 48\%, I 62\%, 3 months M $26 \%$ I $24 \%$, 6 months M $10 \%$, I $12 \%, 12$ months both $0 \%$

- Residual swelling at 10 days; M 85\%, $184 \%$; weeks M 55\%, $168 \%$, 6 weeks M 32 , I 44 \% 3 months M $11 \%$

I $15 \% ; 6$ monthe both $3 \%, 12$ months both $0 \%$

- Imparred activity at 10 days; M 6\%\%, I 84\%; 3 weeks $\mathrm{M} 29 \%$, I $39 \%, 6$ weeks $\mathrm{M} 18 \%, 118 \%, 3$ months $\mathrm{M}, 3 \%$,

$16 \%, 6$ montlas $\mathrm{M} \mathrm{O} \%, 13 \% ; 12$ months both $0 \%$

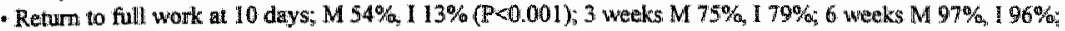
at 3 and 6 months both $100 \%$

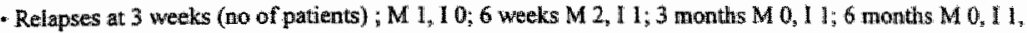

12 months both 0

- Functional instability at 3 weeks; M 20\%, I $22 \%$, weeks M 13\%, 19\%; months M $8 \%, 114 \% ; 6$ months

both $8 \%, 12$ months both $3 \%$

Assessments; 3,6 and 12 months

- Free of symptoms (mean duration in weeks (range)): Strapping $12(2-20)$, Cast $22(8-40), 0$ peration $26(16-46)$

$2 \%$ loss to follow up

- Pain after I year: Strapping 0/12, Cast 1/17, Operation $1 / 16$

- Swelling after 1 year: nome

- Pain and Swelling: Strapping 0/12, Cast 0/17, Operation 5/16

no intention to treath andysis

- Functional instability: none

- Functional instability, pain and/or swelling: Strapping $5 / 12$, Cast $7 / 17$, Operation $6 / 16$

Assessments at 6 weeks

- Hospital stay; operation 4.2 days, cast 1.6 days and strapping 1.2 days

- Free of symptoms (pain and ankle tillt): operation 31/32, cast 23/30, strapping 22/23

Assessmerts at 1 week, and at 8 months (on average)

- Mean weight bearing improvement (0-4) (SD): Plaster 2.04 (1.54), Early mobility $2.2(1.39)$

- Mean pain improvement (0-4) (SD): Plaster -2.08 (1.26), Early mob -1.84 (1.22)

- Mean swelling improvement (0-4) (SD): Plaster -0.51 (0.58), Early mob -0.34 (0.64)

- Long term:

- Symptom free: 5 ws 8

- Disability, pain or swelling when very active; 3 vs 4

- Disability, pain or swelling with normal activities; 6 vs 5

Assessments at 2, 4 and 6 weeks

- Mean days till weight bearing (SD): CS 1.8 (2), A 1.8 (2.7)

- Meran days thil nominal walking (SD): CS 11.5 (10.3), A 10 (9.3)

- Mean days till nomal ADL (SD): CS $7(10)$, A $7(8.6)$

- Mean days till morinal leisure actiwities (GD): CS $23(20.5), A 19.4(18.2)$

- Miean days off work (SD), CS 5.2 (7.5), A 3.6 (4)

- Mean days till disappearance of swelling (SD): CS 27.4 (25.8), A 25.9 (21.3)

- Mean days till pain free (SD); CS $23(24.5)$, A $19.9(17.7)$

Evaluation at 2 and 44 weeks

- patient assessment: no differences (no data ass well)

$23 \%$ drop outs $74 \%$ loss to follow up mo intention to treat analysis

$26 \%$ drop outs no intention to tristat atralysits

$15 \%$ loss to tollow up no Ankention to treat and a

$12 \%$ loss to Iollow up tho intention to treat analysis

- Clinical evaluation (very good/good/satisfactory/bad): Tape (22/12/7/3), Malleotrain $(25 / 10 / 4 / 5)$

- Patient satisfaetion (very salisfied/satisfied/neutral/unsatisfied): Tape (12/25/6/1),

Malleotrain (22/16/3/3)

- Re-uptake of work: Tape 20 days, Malleotrain 22 days

- Re-uptake of sports activities (yes/no/not applicable): Tape (36/6/2), Malleotrain (32/7/s) 


\begin{tabular}{|c|c|c|}
\hline 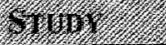 & 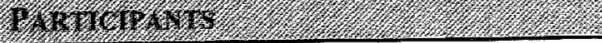 & 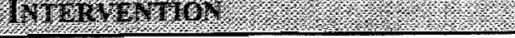 \\
\hline & $\begin{array}{l}60 \text { patients with ankle sprains, divided over two groups of } \\
27 \text { each } \\
\text { Median (range) age } 22(16-45) \text { and } 21(16-35) \\
\text { years } \\
\text { Gendler. } 18 \text { males in each group } \\
\text { Pogenostic wariables given }\end{array}$ & $\begin{array}{l}\text { Al patients: ice, elevation of leg and } \\
\text { crutches } \\
\text { * Aircast for } 10 \text { days, as litule weight bearing } \\
\text { as passible; } 6 \text { weeks wear in shoe } \\
\text { - Plaster for } 10 \text { days; } 6 \text { weeks circular cast }\end{array}$ \\
\hline & $\begin{array}{l}80 \text { patients with grade } 3 \text { lateral ligament ruptures within } \\
\text { previous } 24 \text { hours, divided ower two groups of } 36 \text { and } 37 \\
\text { patients } \\
\text { Mean age (range) } 24(17-48) \text { and } 22(18-38) \text { years } \\
\text { No prognostic variables given }\end{array}$ & $\begin{array}{l}\text { - Aircast for } 16 \text { weeks, with exercise instruc- } \\
\text { tion } \\
\text { - Cast for } 1 \text { week, } 5 \text { weeks walking cast }\end{array}$ \\
\hline (3) & $\begin{array}{l}150 \text { patients with severe lateral ligament sprains, divided } \\
\text { over three groups of } 50 \text { each } \\
\text { Prognostic variables not given }\end{array}$ & $\begin{array}{l}\text { - Semi-elastic bandage for } 1 \text { week, followed } \\
\text { by elastic bandage for } 1 \text { to } 3 \text { weeks. Full } \\
\text { weight bearing allowed } \\
\text { - Plaster cast for } 4 \text { weeks. Full weight bearing after } \\
1 \text { week. } \\
\text { - Operation and } 4 \text { weeks plaster cast. Full weight } \\
\text { bearing after } 1 \text { week. }\end{array}$ \\
\hline mox & $\begin{array}{l}73 \text { patients with grade } 2 \text { and } 3 \text { ankle sprain, divided over } \\
\text { two groups of } 39 \text { and } 34 \text { patients. } \\
\text { Meary age } 28 \text { years } \\
48 \text { men, } 28 \text { women } \\
\text { Grade } 2 \text { to grade } 3 \text { ratio }=2: 1 \\
\text { Type of employment similar per group }\end{array}$ & $\begin{array}{l}\text { - Air stimup ankle brace } \\
\text { - Compression bandage } \\
\text { All patients: weight bearing and early motion } \\
\text { when comfortable }\end{array}$ \\
\hline 3.t. & 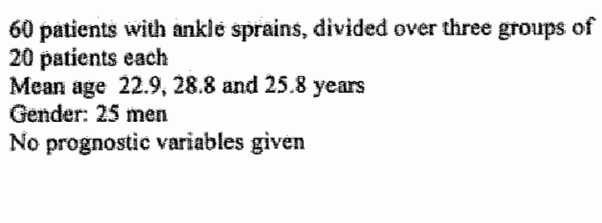 & $\begin{array}{l}\text { Electric stimullation (simus current, } 10 \text { ms, } \\
50 / 100 \mathrm{~Hz}, \mathrm{CP} \text { form) for } 4-8 \mathrm{mim} \\
\text { - Ultrasound (continuous, } 0.5 \mathrm{~W} / \mathrm{cm}^{2} \text { ) } \\
\text { for } 5 \text { - } 10 \mathrm{~min} \\
\text { placebo ultrasound for } 5-10 \mathrm{~min} \\
\text { All patients: elevate leg, crutches, eight bearing } \\
\text { when possible, elastic bandage }\end{array}$ \\
\hline 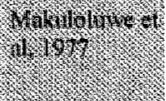 & $\begin{array}{l}80 \text { patients with milld or modkerate ankle sprains, divided } \\
\text { over two groups of } 40 \text { patients each. } \\
\text { Prognostic wartables not given }\end{array}$ & $\begin{array}{l}\text { - Immobilisation with elastoplast } \\
\text { - Ultrasound ( } 1.5 \mathrm{~W} / \mathrm{cm}^{2} \times 4 \text { minutes) and someti- } \\
\text { mes ace (5 muinutes before first treatment) }\end{array}$ \\
\hline (1) & $\begin{array}{l}37 \text { patients with lateral ligament sprain of the ankle, in } \\
\text { previous } 48 \text { hours, divided ower two groups of } 18 \text { and } 18 \\
\text { patients } \\
\text { Mein age } 22.9 \text { (SD } 6.3 \text { ) and } 26.8 \text { (SD } 9.7 \text { ) years } \\
\text { Number of males per group } 8 \text { and } 2\end{array}$ & $\begin{array}{l}\text { - Pulsed short-wave therapy with circuplode } \\
\text { (82 Hz: intensidy } 19.6 \text { W, } 3 \text { sessions of } 15 \text { minu- } \\
\text { tes each on } 3 \text { consecutive days) } \\
\text { - Placebo pulsed shortwave therapy } \\
\text { All patients: tubigrip, elevate leg while at rest, } \\
\text { axillary crutches, bear weight when possible, } 500 \\
\text { mg Paracetamol, avoid co-interventions. }\end{array}$ \\
\hline
\end{tabular}




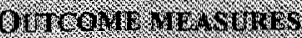

Assessments at baseline; and ias, $3 ; 5$ and 7 weeks, median follow-up 15 months

- Relapses: Aireast $8 / 27$, Plaster 10/27 (unclear when measured)

- Instabillity: Aircast 9/27, Plaster $12 / 27$ (unclear when measured)

- Pair free: Aircast 18/27, Plaster 19/27 (unclear when measured)

- After 15 months

- Swelling: Aircast 1/27, Plaster $3 / 27$

- No sports limitation : Aircast $17 / 27$. Plaster $7 / 27$

- Complete re-uptake of sperts: Aircast 17/27, Plaster 10/27

- Talar tilt: Aircast $3.82(\mathrm{n}=22)$, Plaster $3.350,(\mathrm{n}=20)$

- Arterior draw sign: Aircast $6.32 \mathrm{~mm}(\mathrm{n}=22)$, Plaster $6.15 \mathrm{~mm}(\mathrm{n}=20)$

Assessments at $\mathbb{1}$ and 7 weeks and 3 months and 11 year

- Injury score (0-48 points)(graph); at 1 week; Aircast 30 points, Cast 33 points; at 7 weeks; Aircast 7, Cast 17, at 3 months; Aircast 6, Cast 8 points

- Natural walk at 1 weels: Aircast $22 \%$, Cast $0 \%$; at 7 weels: Aircast $100 \%$, Cast $11 \%$, at 3 and 12 months both $100 \%$

- Days of work at $\mathbb{1}$ week; Aircast 1:7\%, Cast 19\%; at 7 weelis; Aircast 100\%, Cast $81 \%$ at 3 and 12 months both $100 \%$

- Days off spont at I week, Aircast $0 \%$, Cast 0\%, at 7 weeks; Aircast 11\%, Cast 0\%; at 3 months; Aircast $86 \%$. Cast $49 \%$; at 1 year; Aircast $86 \%$, Cast $89 \%$

Assessments after 2 years

- Recurrent sprains: Bandage 6/36, Cast 10/47, Operation and Cast 8/34

- Reduced sporting activity: Bandiage $8 / 36$, Cast $7 / 47$, Operation and Cast $4 / 34$

- Fear of giving way (none/on fat surfaces/on rough surfaces): Bandage 17/6/13, Cast 32/0/15, Operation and Cast $31 / 0 / 3$

- Tendemess: Bandage 7/31, Cast 4/42, Operation and Cast 2/26

- Talar tilt $>11 \circ$ : Bandage $9 / 30$, Cast $5 / 40$, Operation and Cast 3/26

- Anterior draw siga more than 6 mm: Bandage $7 / 30$, Caist $9 / 40$, Operation and Cast $3 / 26$

Assessments at 3-5 days, 2,4 and 10 weeks

- active ROM in dorsal tlexionmplantar flexion in \% of the uninjured anklle

- Air stimup 65, 77, 84, 95\%

- Compression $58,77,86,87 \%$

- SIP score: no data given

- Sick leave from work: Air stimp 5.3 (range 0-26) days, Compression 9.1 (range 0-21 days)

- Karlsson's score $(p<0.05)$

- Air stimup 23, 53,63, 71

- Compression $20,57,64,73$

Assessments every day for 15 days

- Swelling (graph)

- Pain (graph)

- Mobility (graph)

- Normal waiking pattern (graph)

$9 \%$ losis to follow up no intention to treat andysis

Drop auts range from $22 \%$ to $36 \%$ no intention to treat analysis

$21 \%$ loss to follow up no intention to treat analysiss

$3 \%$ drop outs no intention 10 treat analysis

co-intervention ice mo intention to trecal analystis

$13.5 \%$ loss to follow up no intention to treat analysis
- Meas number of Paracetamol tablets taken $0.44(0.51)$ v $0.29(0.55)$

"Number of hours spent with ankle elevated $1.87(0.77)$ w $1.77(0.57)$

- Pain 2.37 (1.19) vs 2.34 (1.47)

" Time to weight bearing 5.78 (3.20) vs 2.88 (1.5) days

- Yolunetry of the foot (graph only) 


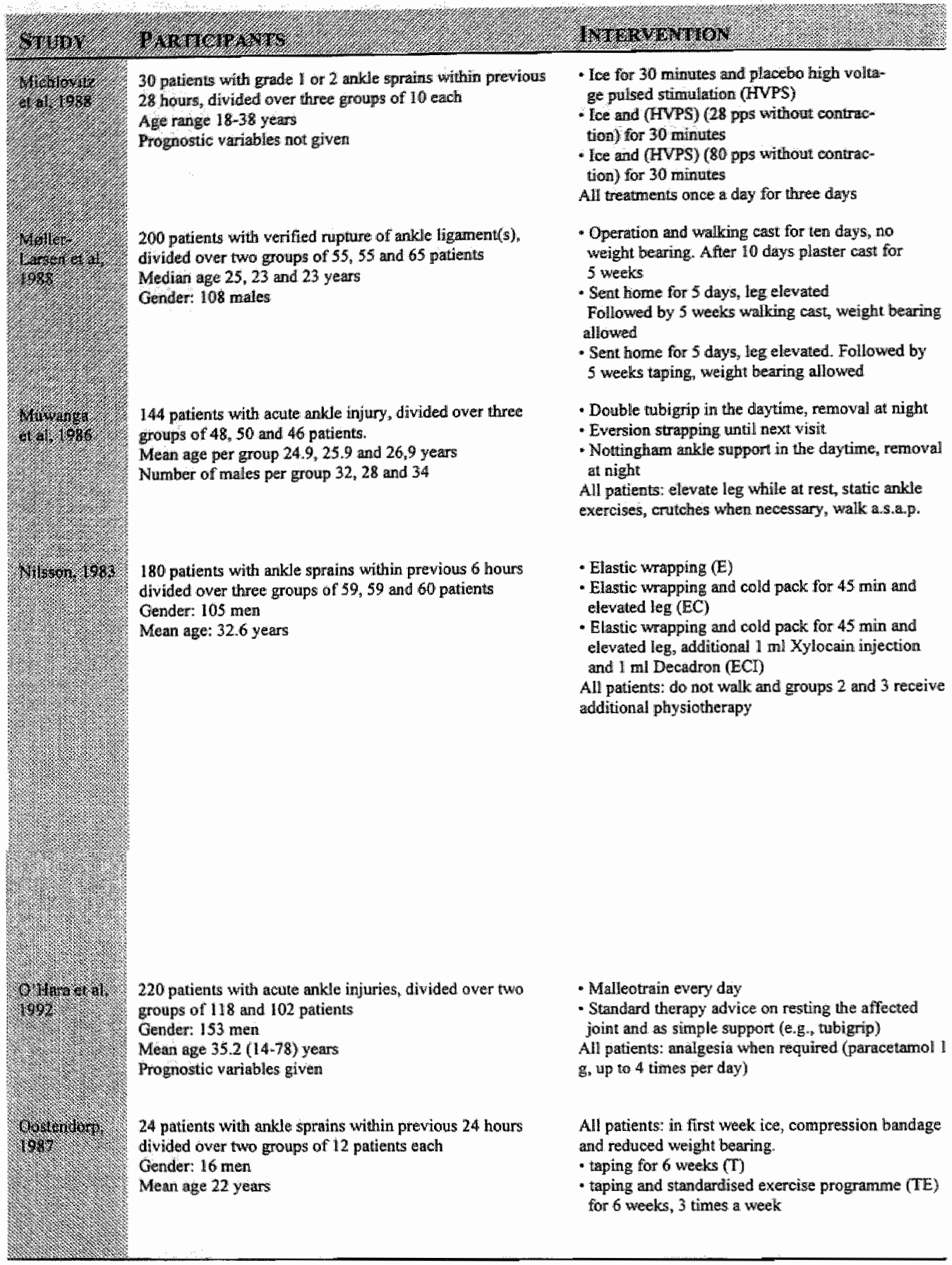


Assessments at 1 and 3 days

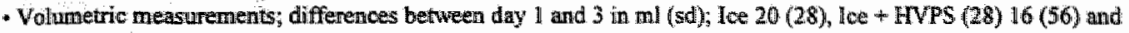
Hoe + HVPS (80) $7(39)$

- ROM dorsal fiexion; differences between day 1 and 3 in degres (SD); loe $6(2)$, lce + HVPS (2s) 7 (7) and loe 4 HVPS $(80) 4(3)$

- Pain on day I (pre and post treatment), differences on VAS: Ice 2.5 (1.43), lce + HVP (28) 3.65

(2.1) low HVPS (80) $3.7(2.36)$

Assessmients at 5 meeks and one year

- Sistisfaction (no data)

- Mechanical stability (no datai)

- Other outcomes unclear

$12.5 \%$ loss to follow up no intention to treat analysis

Assessments at intake and at 10 days

- Bear weight on injured foot (increase at 10 days: tubigrip $40 \%$, eversion strapping $62 \%$ and Nottinghan ankle support $67 \%$ )

- ROM: Nottingham ankle support superior over other two $(\mathrm{p}=0,00174)$

- Confidence: Nottingham ankle support superior over other two ( $\mathrm{p}=0.02)$

- Convenience and hygiene: Nottingham ankle support and tubigrip superior to eversion strapping

Assessments at $1,3,7,14$ and 21 days

- Skin temperature

- Swelling (graph): on day 3: (E) $86 \mathrm{mil}$, (EC) $73 \mathrm{ml}$, (EC) $55 \mathrm{ml}$; on day 7: (E) $55 \mathrm{ml}$, (EC) $35 \mathrm{ml}$, (ECl) $40 \mathrm{ml}$

- Pain:

- after 1 day: constant (E) $n=24,(E C) n=14,(E C I) n=2$; when walking $(E)$ ma3s, (EC) $n=44,(E C I) n=46$; none (E) $\mathrm{n}=0,(\mathrm{EC}) \mathrm{n}=1,(\mathrm{ECI}) \mathrm{n}=9$

- after 7 days: constant $(E) n=7,(E C) n=1,(E C) n=0$; when walking $(E) n=31,(E C) n=30,(E C I)$ in $=17$; none (E) $\mathrm{n}=21,(\mathrm{EC}) \mathrm{n}=28$, $(\mathrm{ECI}) \mathrm{n}=40$

- Analgusics used (E) $n=59$ (mean 4 tablets), (EC) $n=59$ (mean 2.9 tablets), (ECI) n=57 (mean 1.4 tablets)

- Walking ability after 7 days: normal (E) 14, (EC) 24, (ECl) 34; limp (E) 38, (EC) 35, (ECl) 21 ; unable to walk (E) 4. (EC) $0,(\mathrm{ECl}) 1$

- Limitation of ankle movements (graph);

- at 3 days (E) $14^{\circ},(\mathrm{EC}) 11.5^{\circ},(\mathrm{ECl}) 8.5^{\circ}$

*at 7 days (E) $12^{\circ},(\mathrm{EC}) 18.5^{\circ},(\mathrm{ECl}) 6^{\circ}$

- Cessation of treatment:

* at 7 days (E) $n=16,(\mathrm{EC}) \mathrm{n}=21,(\mathrm{ECl}) \mathrm{n}=29$

*at 14 days (E) $n=24,(E C) n=28,(E C) n=21$

- at 21 days (E) $n=16,(\mathrm{EC}) \mathrm{n}=10,(\mathrm{EC}) \mathrm{n}=6$

- Days off work (E) 12.6, (EC) 11.3, (EC) 9.5

Follow-up between 3 and 6 months (mean 4.3 months) and at 3 years (mean 32.6 months)

Assessments ewery day for 14 days

"Pain ( 7 en VAS) (graphs); at rest, at night, during activity (endpoints p<0.05 for all three)

- Limitation of activity ( $7 \mathrm{~cm}$ VAS)

- Ability to work (differences). Malleotrain $49 \%$, Control $45 \%$

- Improvement (6 point scale): Malleotrain 4.37 units, Control 3.94 units

- Meification diuring 14 days (median): Malleotrain 11, Control 25.6 pills

Assessments at 6,12 and 24 weelss. Date are presented graphically only.

\%a in graphis do

- Pain (VAS): 6 weeks (T) $25 \mathrm{~mm}$, (TE) $18 \mathrm{~mm}$, 12 weeks (T) $15 \mathrm{~mm}$, (TE) $10 \mathrm{~mm}$; 24 weeks (T) $10 \mathrm{~mm}$, (TE) $5 \mathrm{~mm}$

* Fear of giving way (\%): 6 weeks (T) 65, (TE) 30; 12 weeks (T) 45, (TE) 20,24 weeks (T) 40, (TE) 10

- Re-uptake of work (\%) 6 weeks (T) 85, (TE) 86; 12 weeks (T) 90, (TE) 93; 24 weeks (T) 93, (TE) 95

- Re-uptake of sports training (W6): 6 weeks (T) 30, (TE) 63; 12 weeks (T) 45, (TE) 90; 24 weeks (T) 75, (TE) 95

ot correspond whth numbers of pyatients in groups

- Re-uptake of competition sports (\%): 6 weeks (T) 20, (TE) $50 ; 12$ weeks (T) 40, (TE) 80; 24 weeks (T) 70, (TE) 95

Wot all patients received the same injection therapy; $10 \mathrm{pa}$ thents received Celostone instead

Belween 5\% and $10 \%$ missing no intention to treat analysis: 


\begin{tabular}{|c|c|c|}
\hline 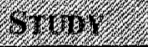 & 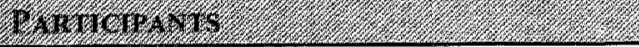 & 1) \\
\hline 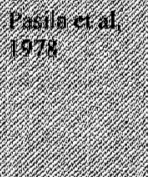 & $\begin{array}{l}321 \text { patients with arkle sprain in prewiows } 4 \text { days, divided over } \\
\text { ghree groups of } 107 \text { each } \\
\text { Mean age } 30.3,29.8 \text { and } 32.6 \text { years } \\
\text { Gender: } 50 \% \text { men }\end{array}$ & $\begin{array}{l}\text { - Dispulse (D) ( } 318 \text { W/sec) } \\
\text { - Curapulse (P) (40 W/sec) } \\
\text { - Placebo (P) } \\
\text { All patients: treatment for } 20 \text { minutes on } 3 \\
\text { successive days, } 60 \text { elevation, avoidance of } \\
\text { medication, elastic bandage after treatment }\end{array}$ \\
\hline & $\begin{array}{l}50 \text { paliemts with grade } 1 \text { and } 2 \text { ankle sprains in previous } 72 \\
\text { lours, divided ower two groups of } 25 \text { each } \\
\text { prognostie variables not given }\end{array}$ & $\begin{array}{l}\text { - Diapulse for } 70 \text { minutes } \\
\text { - Placebo for } 70 \text { minutes }\end{array}$ \\
\hline 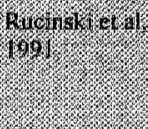 & $\begin{array}{l}30 \text { patients with grade } 1 \text { and } 2 \text { ankle sprains in previous } 24 \\
\text { pours, divided over three groups of } 10 \text { each } \\
\text { prognostic variables not given }\end{array}$ & $\begin{array}{l}\text { - Elastic wrap for } 30 \text { minutes and } 45^{\circ} \text { elevation } \\
\text { - Intermittent compression ( } 40-50 \text { mm } \mathrm{HG}, 60 \mathrm{sec} \\
\text { on, } 15 \text { sec off) for } 30 \text { minutes and } 45^{\circ} \text { elevation } \\
\text { - } 45^{\circ} \text { Elewation for } 30 \text { minutes }\end{array}$ \\
\hline 36 & $\begin{array}{l}184 \text { patients with grade } 1 \text { and } 2 \text { ankle sprains in previous } 24 \\
\text { hours, divided ower three groups of } 60,60 \text { and } 64 \text { patients } \\
\text { progmostic variables not giwen }\end{array}$ & $\begin{array}{l}\text { - Athdetic tape for } 72 \text { hours: } \\
\text { - Gel cast for } 72 \text { hours } \\
\text { - Daily new strapping } \\
\text { All patients: NSAIDS for } 5 \text { days, ice bath for } 5 \text { min, } \\
\text { walk on inwolved ankle until sensation returned ( } \\
\text { times), balance board, wheight bearing when } \\
\text { possible, stretching exercises, resistive exefcises: } \\
\text { home program; resistive ankle exercises, walking } \\
\text { exercises }\end{array}$ \\
\hline 3) & $\begin{array}{l}143 \text { patients with ankle sprains, in previous } 24 \text { hours, divided } \\
\text { over two groups (numbers tuknown) } \\
\text { Median age } 24 \text { years } \\
\text { Gender: } 113 \text { men } \\
\end{array}$ & $\begin{array}{l}\text { - Immediate cold therapy by inflated cooling anklet } \\
\text { for } 30 \text { mim, elevate leg while supine at } 49 \\
\text { - Simulated therapy with non inflated anklet for } 30 \\
\text { min, while supine but not elewated } \\
\text { All patients high dose NSADS ( } 2400 \mathrm{mg} \text { daily), } \\
\text { elastic support } \\
\text { co-intervention: paracetamol } 500 \mathrm{mg}\end{array}$ \\
\hline 17ving & $\begin{array}{l}120 \text { patients with fresh anklo sprain, divided ower three groups } \\
\text { of } 40 \text { patients } \\
\text { Mena age (SD) } 25.9(7.8) 24.9(8.6) \text { and } 24.5(3.5) \text { years } \\
\text { Gender: } 23,27 \text { and } 25 \text { nales } \\
\text { Sprognostic variables given }\end{array}$ & $\begin{array}{l}\text { - Cast for } 3 \text { weeks, } 2 \text { weeks no weight bearing, last } \\
\text { week partial weight bearing } \\
\text { - Aircast splint up to } 6^{\text {th }} \text { week, no weight during f } \\
\text { week } \\
\text { - Unwa's paste dressing with partial weight for two } \\
\text { weeks, then tane up to } 6 \text { weeks }\end{array}$ \\
\hline $106 \%$ & $\begin{array}{l}61 \text { patients with partial sprains of lateral ankle ligaments, } \\
\text { divided over two groups of both } 24 \\
\text { Meat age } 25(7,2) \text { years } \\
\text { Gender: } 19 \text { women, } 29 \text { men }\end{array}$ & $\begin{array}{l}\text { - Training on wobble board: } 15 \text { minutes a day, } 12 \\
\text { weeks } \\
\text { - No training } \\
\text { All patients: I week compression bandage, } 2 \text { days } \\
\text { immabilisation, ellevate leg, avoid straining of } \\
\text { ligaments, avoid resumption of sports until pain free } \\
\text { in activities of daly life }\end{array}$ \\
\hline
\end{tabular}


Assessments at 1 and 3 days

- Strength measurement: changes between day 1 and 3

7 \% drop oats

- abdaction: (D) $21 \mathrm{~N}$, (C) $21 \mathrm{~N}$, (P) $20 \mathrm{~N}$

no intertion to

- adduction: (D) $17 \mathrm{~N}$, (C) $21 \mathrm{~N}$, (P) $20 \mathrm{~N}$

treat aralysis

- Weight bearing; changes between day 1 and 3

- helt (D) $9.5 \mathrm{~kg}$, (C) $10.6 \mathrm{~kg}$ (P) $9.5 \mathrm{~kg}$

* toes: (D) $11.1 \mathrm{~kg}$, (C) $10.4 \mathrm{~kg}$, (P) $8.8 \mathrm{~kg}$

- ROM: change between dlay 1 and 3

- dorsal flexion: (D) $5.1^{\circ}$, (C) $6.3^{\circ}$, (D) $5.1 \%$

- plantar flexion: (D) $5.6^{\circ}$, (C) $4.8^{\circ}$ (P) $3.4^{\circ}$

- eversion: (D) $3.1^{\circ}$, (C) $3.4^{\circ}$, (P) $2.6^{\circ}$

- inversion: (D) $2.9^{\circ}$, (C) $4.0^{\circ}$, (P) $2.8^{\circ}$

- Swelling (circumfenence) change between day 1 and 3

- (D) $4.5 \mathrm{~mm}$, (C) $5.0 \mathrm{~mm}$, (P) $2.6 \mathrm{~mm}$.

- Volumetric measurement: change between day 1 and 3

- (D) $30 \mathrm{mill}$, (C) $40 \mathrm{mi}$, (P) $36 \mathrm{mll}$

- Walking impairment: change between day 1 and 3

- (D) 1.0, (C) 0.9 , (P) 0.7

Assessments before and after treatment

- Volumetric differences in \% (sd) of total foot volume: diapulse 4.7 (1.4), placebo $0.95(0.8)$

- Pain reduction (0-10 scale) diapulse $16 / 25$, placebo $8 / 24$

- Ability to bear weight or walk: no data

One treatruerist: orty

no intiention to troat anilys

one treditiment only

Assessments at 3,13 and 21 days

- Return to duty;

- 3 days: 3 -day strap $n=24,3$-day gel cast $n=20$, daily strap $n=36$

- 13 days: 3 -day strap $n=30,3$-day gel cast $n=32$, daily strap $n=24$

- 21 days: 3 -day strap $n=6,3$-day gel cats $n=12$, daily strap $n=0$

- Swelling by figure of 8 measurements: no data

Assessments at intake and at 7 days

"Soft cissue swelling at day" 7: $46 \%$ vs $40 \%$ improventent

- Sevenity of injury at day $7: 88 \%$ vs $79 \%$ improventent

- Ability to bear weight: $36 \%$ vs $29 \%$

- ROM: no alifferences

* Parg relief: no differrences

$18 \%$ loss to follow up cointervention: paracetamol no interition to troat antilysis.

$3 \%$ drop suns $14 \%$ lose to follow up no intertion th treent tandysuls

$21 \% \operatorname{logs}$ to follow up no intention to treat analygis

- Pain at rest: week. 1 (12 ws 7 ), week 6 (1 vs 04 , week 12 (10 vs 1$)$

* Pain during walking: week 1 (20 vs 20), week 6 (6 ws 5), week 12 (1 ws 1$)$

- Pain during sports activities: week 1 (23 vs 23 ), wek 6 (18 ws 18), wheek 12 (4 ws 7 )

- Relapses al 12 weeks: 6 ws 13

- Feeling of giving way: 0 vis 6

- Use of brace or tape: 4 vs 5

- Change in sponts habits: not reported 


\begin{tabular}{|c|c|c|}
\hline (6) & 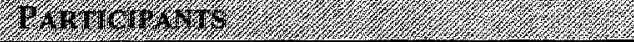 & (1) \\
\hline (3) & $\begin{array}{l}\text { 34 patientw with an inversion injury in previous } 24 \text { hours } \\
\text { divided over three groups of } 12,12 \text { and } 10 \text { patients } \\
\text { Mhean age } 20.35 \text { (sd } 1.5 \text { ) years } \\
\text { Gender: } 28 \text { males }\end{array}$ & 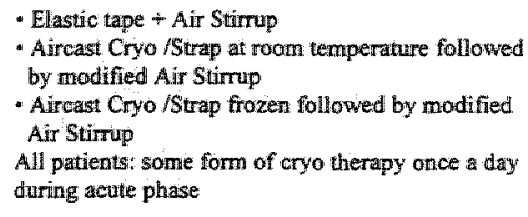 \\
\hline$y^{4}$ & $\begin{array}{l}154 \text { patients with an inversion injury, in previous } 48 \text { hours, } \\
\text { divided ower two groups of } 74 \text { and } 80 \text { patients } \\
\text { Prognostic variables not giwen }\end{array}$ & $\begin{array}{l}\text { - Ultrasound } \\
\text { - Sham ultrasound (no blinding procedures } \\
\text { deseribed) } \\
\text { All patients: local ice packs, exercises and wobble } \\
\text { board training, tubignip and crutches when } \\
\text { necessary }\end{array}$ \\
\hline 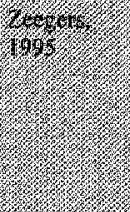 & $\begin{array}{l}\text { 264 patients with } X \text {-ray confirmed ankle sprain, dividied over } \\
\text { four groups of } 59,60,62 \text { and } 62 \text { patients } \\
\text { Mean age (range): } 26.7(15-49), 25,2(15-50), 26.6(15-50) \text { and } \\
23.9(15-46) \text { years } \\
\text { Gender. } 37,46,48 \text { and } 39 \text { males } \\
\text { Prognostic variables given }\end{array}$ & $\begin{array}{l}\text { - Taping (Coumans) for } 3 \text { meeles, followed by } \\
2 \text { weeks of tubigrip } \\
\text { " Adidas Adimed Stabil shoe conbined with } \\
\text { wbigrip for the night for } 5 \text { weeks } \\
\text { - Aircast with tubigrip for } 5 \text { weelss } \\
\text { - Elastic sotk for } 5 \text { weeks } \\
\text { All patients: walking instructions }\end{array}$ \\
\hline 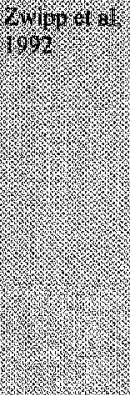 & $\begin{array}{l}1100 \text { patients with lateral ankle sprains, divided over four groups } \\
\text { of, } 52,50,48 \text { and } 50 \text { patients } \\
\text { prognostic variables not given }\end{array}$ & 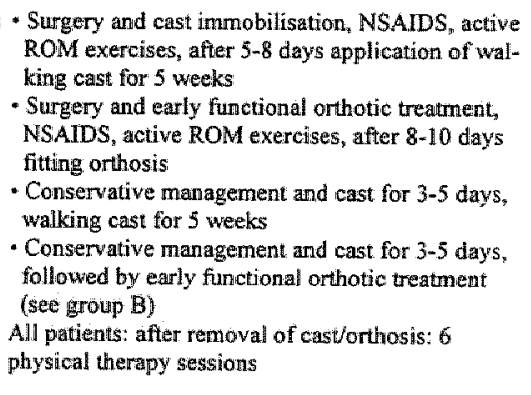 \\
\hline
\end{tabular}




\section{Outronie inteasures}

\section{Notes}

Assessments on ankle function (100 point scale) each day post injury: no difference

co-interremtion: cryo therapy in all groups $29 \%$ drop outs no intention to treat analysis.

- Combined 15 -point measure of swelling, discomfor, degree of limp, pain on anversion, pain on plantar flexion: no data provided: resuls reported as no difference

310 dropouts in ultrascound. group. $29 \%$ drop ouls in sham ulitrasound group no intontion to veat analysis:

Assessments at 1, 3 and 5 weeks, 3 months, 1 and 5 years

- Nomal walking after I week: Tape $81 \%$, Adidas $91 \%$, Aircast $76 \%$ and Elastic sock $72 \%$, after 5 weeks:

$8 \%$ drop outs $42 \%$ loss to

Tape $98 \%$ Adidas 100\% Aircast $98 \%$ and Elastic sock $97 \%$

- Normal walking on stairs: no data

- Normal cycling: no diala

- Stability after 1 week: Tape $65 \%$ Adidas $83 \%$, Aircast $76 \%$ and Elastic sock 65\%; wer 5 weeks: Tape $97 \%$,

Adidas $97 \%$, Aircast $98 \%$ and Elastic sock $89 \%$

- Painfree at 1 week: Tape 49\% Adidas $60 \%$. Aircast $41 \%$ and Elastic sock 42\%; after 5 weeks: Tapa $86 \%$, Adidas $83 \%$, Aircast $76 \%$ and Elastic sock $80 \%$.

- Days off work: Tape 15, Adidas: 17.11, Aircast 17.1 and Elastic sock 15.5

- Swelling at 5-6 weeks; Tape 16\%, Adidas 5\%, Aircast $21 \%$, Elastic sock $26 \%$

follow up at 3 months

$25 \%$ logs to

collow un at 1

year

$39 \%$ loss to

collow wip

years

no infention to

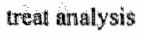

Assessments it 3 and 12 months

- Ankle performance: unclear and no difference

$7 \%$. 105 to

follow up at 3

- Joint stability: unclear and no difference

months

$16 \%$ loss to

follow up at 1

year

$20 \%$ loss to

follow up at 2

years

no intention to

tresul whalysis 
The two best studies are the ones by Barker et $\mathrm{al}^{1 / 3}\left(70\right.$ points) and McGill et al ${ }^{42}$ (63 points). Both study pulsed short wave therapy (PST) versus placebo.

Barker et al. ${ }^{18}$ randomise patients with lateral ankle sprains over 2 groups of 34 and 39 patients. They administer PST on 3 consecutive days for 45 minutes to both groups, either in a verum or a placebo fashion. Additionally, all patients receive tubigrip, elbow crutches and analgesics. Assessments on $1,2,3,8$ and 15 days after randomisation show no efficacy of PST over placebo on range of motion, walking velocity, step length, pain, swelling or other walking indices. Methodological points were lost by the lack of an intention to treat analysis and a $1.0 \%$ drop out rate.

McGill et al. ${ }^{42}$ randomise patients with lateral ankle sprains over 2 groups of 18 patients each. They administer PST on three consecutive days for 15 minutes in a verum and a placebo fashion. All patients receive additional tubigrip, crutches and analgesics. Assessments at 1,2,3,8 and 15 days after randomisation show no effects on number of analgesics taken, pain, time to weight bearing on injured foot or swelling. Also here no intention to treat analysis was performed and on average $13.5 \%$ of patients were lost during follow up.

As can be seen from Table 3, quite a number of outcome measures per study have been used. Outcome measures that were most prominently reported upon were pain, swelling and days of sick leave. Since the format of most outcome measures differed, we used an effect size calculation to make the outcomes comparable over studies. Most of the studies failed to provide adequate data to calculate effect sizes. For these studies results are expressed as positive $(+)$, negative $(-)$ or undecided (?).

In table 4 the outcomes on pain, swelling and sick leave during the first six weeks are reported for the five previously detected subgroups.

Table 4: Effects of interventions in acute ankle sprains in the first six weeks

\begin{tabular}{|c|c|c|c|c|c|}
\hline Whating & 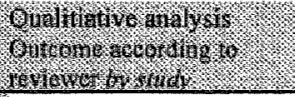 & 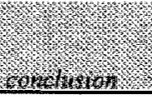 & 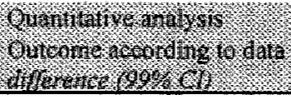 & 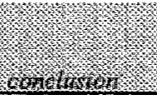 & 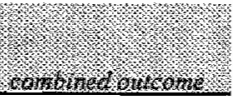 \\
\hline 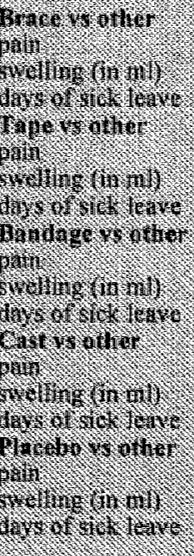 & 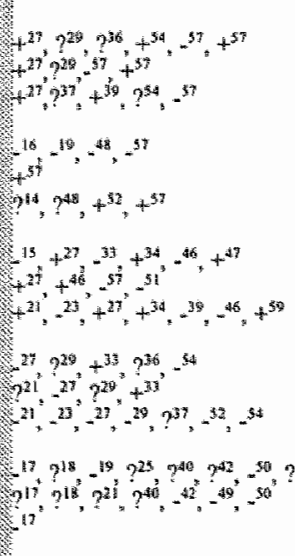 & $\begin{array}{l}\text { pain relief } \\
\text { reduction } \\
\text { undecided } \\
\text { no pain relief } \\
\text { reducttion } \\
\text { reduction } \\
\text { undecided } \\
\text { undecided } \\
\text { undecided } \\
\text { undecided } \\
\text { undecided } \\
\text { increase }\end{array}$ & 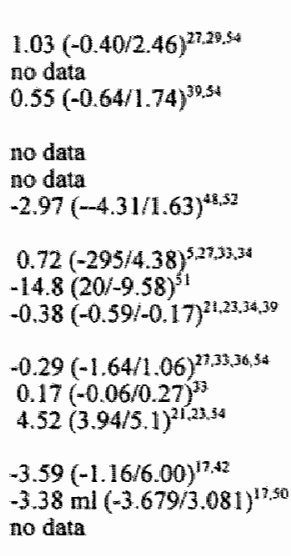 & $\begin{array}{l}\text { rediuction } \\
\text { no pain relief } \\
\text { no reduction } \\
\text { reduction } \\
\text { no pain relief } \\
\text { no reduction } \\
\text { increase } \\
\text { no pain relief } \\
\text { no reduction }\end{array}$ & $\begin{array}{l}\text { undecided } \\
\text { reduction of swelling } \\
\text { undecided } \\
\text { no pain relief } \\
\text { reduction of swelling } \\
\text { reduction: } \\
\text { undecided } \\
\text { undecided } \\
\text { reduction } \\
\text { undecided } \\
\text { undecided } \\
\text { increase } \\
\text { no pain relief? } \\
\text { no reduction } \\
\text { undecided }\end{array}$ \\
\hline
\end{tabular}

treduction compared to other intervention(s); - no reduction; ? no differemce 
From both the qualitative as well as the quantitative analysis brace therapy seems to provide some pain relief, although not statistically significant (quantitatively) nor consistent (qualitatively). The qualitative analysis regarding tape shows no pain relief. However, quantitative data supporting this claim are lacking. The other interventions do mot show clear benefits. Placebo therapy shows no pain relief, both quantitatively as well as qualitatively .

Both quantitative as qualitative analyses show no clear evidence in reduction of swelling by the studied interventions, although brace shows some swelling reducing properties.

Reduction of sick leave is best accomplished by taping. Both quantitative and qualitative analyses show this. Cast therapy seems to prolong sick leave significantly (quantitatively). For the other interventions the efficacy of the studied therapies remains undecided. Few studies reported side effects. Complications due to surgical therapy were reported as deep venous thrombosis in 4 patients ${ }^{32,38}$, loss of sensation in 6 cases $^{58}$ or infection ( 2 cases). ${ }^{58}$ Deep venous thrombosis also occurred in 2 patients treated with plaster of Paris ${ }^{38}$, while severe dermal lesions were found in 3 patients treated with tape and in 1 patient treated with a bandage.." Tape was also mentioned to be more painful in some cases... $^{45}$

\section{Disicission}

The value of a literature review depends on the success in obtaining the results of all trials that have been conducted on the issue of interest. Despite the intensive search strategy it is possible that relevant studies reported in fora not accessible to us or in languages incomprehensible to us were missed in this review.
When one assesses the methodological quality, the primary goal is to achieve an estimate of both the effects and the chance of bias in the results of the performed studies.

One method of assessing quality is by using a criteria list which tries to measure internal validity, precision of the study and relevance of the choices with respect to population, interventions and measures of effect. Assigning weights to the criteria anticipates the argument that some errors in trial design are more crucial than others. Although controversial, weighting does give some insight into the quality of the performed studies and provides an overview of the credibility of the results. It also enables the reviewed studies to be ranked to some extent, according to their methodological quality. Another advantage of our scoring system is that it is already well known ${ }^{5-8,60}$ and transparent. It permits the reviewer to allocate the distribution of methodological points elsewhere or to adjust scores if this is felt necessary.

The fact that systematic reviews use reported material to judge the quality of the trials under consideration is a consequence of this type of research, but is also cause for concern. It might very well be that the quality of the re ported material does not reflect the quality of the primary research. Especially in trials where more reports of the same research question were generated, one tends to find differences, which in the end translate into differences in methodological scores.

We did not blind the reviewing procedure. From previous investigations ${ }^{59}$ we found that blinding is not likely to bias the findings or results of the methodological score when articles are evaluated by skilled and trained people. 
The 44 trials in this review can be considered the best available evidence when one studies the efficacy of conservative treatment regimens in ankle sprains. Because of the use of random allocation of the patients and the use of control treatments, their potential to supply valid answers is much larger than that of uncontrolled or non-randomised controlled studies. Nevertheless, the observed study quality ranged from very poor ( 9 points) to rather good ( 70 points). Many (avoidable) errors in design and data-analysis were noted. In the studied trials, also the more recent ones, there is still a reluctance (or sloppiness) to assure proper blinding. Of course, some interventions are hard to blind due to the nature of the intervention. However, in the here studied trials many interventions that used apparatuses could have been blinded and in all trials at least attempts could have been made to blind the assessors and data-analysts.

A considerable number of randomised clinical trials studies the efficacy of conservative treatment regimens in ankle sprains. However, many of the reviewed studies showed serious methodological flaws, and much infornation was lacking in the publications. In fact only two studies score above 60 points. There seems to be no relationship between methodologicall quality and year of publication, although trials reporting positive effects were of lower methodological quality. Apparently one continues to repeat methodological flaws over time, and low quality trials are still accepted by indexed (and peer reviewed) journals.

Therefore, we suggest that in the future more attention should be paid to appropriate blinding procedures (where feasible), avoiding drop outs or adjusting for these problems by using intention to treat analysis, to avoid or standardise co-interventions and to ensure better data representation.

We did try to pool the results of the trials on outcome measures as pain, swelling and days of sick leave. However the pooled results should be interpreted carefully. As can be seen from table 4 , in many of the findings rather a small amount of trials contribute to the pooled measure of effect, since a large part of the studies did not present data that allowed pooling. Therefore, also a qualitative assessment of the data was performed, resulting in an overall assessment combining both quantitative and qualitative methods. As can be seen there is much uncertainty about the efficacy of the studied interventions.

Pooling of the two best trials on pulsed shortwave therapy (PST) was impossible; qualitative assessment showed no results of PST.

Larger and methodologically more adequate trials are called for in future to provide more definite and satisfying answers.

\section{Rentrinces}

1. Kannus $P$, Renstrom $P$. Treatment for acute tears of the lateral ligaments of the ankle. J Bone Joint Surg 1991; 73A: 305-12.

2. Cote DJ, Prentice WE, Hooker DN, Shields EW. Comparison of three treatment procedures for minimizing ankle sprain swelling. Physical Therapy $1988 ; 68: 1072-6$.

3. Wilkerson GB, Horn-Kingery HM. Treatment of the inversion ankle sprain: comparison of different modes of compression and cryotherapy. JOSPT 1993; $17(5)$ ): 240-6.

4. Dickersin K, Berlin JA. Meta-analysis: State of the science. Epid Rev 1992; 14: 154-76.

5. Riet $G$ ter, Kleijnen J, Knipschild P. Acupuncture and chronic pain. A criteria based meta-analysis. IClin Epid 1990; 43: 1191-9. 
6. Koes BW, Bouter LM. Hejiden GJMO van der, Kinipschild PG. Physiothempy exencises and back pain. BMJ 1991; 302: 1572-6.

7. Vet HCW de, Bie RA de, Heijden GMG van der; Verhagen AP, Sijpkes P, Knipschild PG. Systematic reviews on the basis of methodological criteria. Physiotherapy $1997 ; 83: 284-89$.

8. Assendelft WJJ, Koes $B W$, Knipschild $P G$, Bouter LM. The relation between methodological quality and conclusions in reviews of spinal manipulation. JAMA $1995 ; 274: 1942-8$.

9. Pocock SJ. Clinical trials; a practical approach. John Wiley \& Sons, Chichester, 1991.

10. Meinert CL. Clinical trials; design, conduct and analysis, Oxford University Press, New York, 1986.

11. Cooper H, Hedges LV eds. The handbook of research synthesis. Russell Sage Foundation, New York, 1994.

12. Rothman KJ. Modern Epidemiology. Little, Brown and Company, Boston/Toronto, 1984.

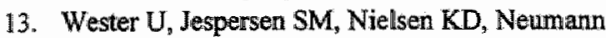
L. Wobble board training after partial ankle sprains of lateral ligaments of the ankle: a prospective randomized study JOSPT 1996; 5: 332-6:

14. Jongen SM, Pot JH, Dunki-Jacobs PB. De behandeling van de verzwikte enkel. Geneeskunde en Sport 1992; 25(3): 98-101.

15. Airaksinen $\mathrm{O}$, Kolari $\mathrm{PJ}$, Miettinen $\mathrm{H}$. Elastic bandages and intermittent pneumatic compression for treatment of acute ankle sprains. Arch Phys Med Rehab 1990; 71 (6): 380-3.

16. Allen MJ, McShane M. Inversion injuries to the lateral ligament of the ankle joint. A pilot study of treatment: Br J Clim Practice 1985; 282-86.

17. Axelsen SM, Bjerno $T$. Laserbehandling af fodledsdistorsion. (Laser treatment in ankle sprains) Ugeskr Laeger 1993; 155(48): 3908-11.

18. Barker AT, Barlow PS, Porter J, Smith ME, Clifton $S$, Andrews L, ODowd WJ. A doubleblind clinical trial of low power pulsed shortwave therapy in the treatment of a soft tissue injury. Physiotherapy 1985; 71(12): 500-4.

19. Bie de RA, Steenbruggen RA, Bouter LM. Effect of laser therapy on ankle sprains, Nederlands Tijdschrift woor Fysiotherapie (English edition) 1989; 99; 4-7.

20. Bradnock B, Law HT, Roscoe K. A quantitative comparative assessment of the immediate response to high frequency ultrasound and low frequency ultrasound ("longwave therapy") in the treatment of acute ankle sprans. Physiotherapy $1995,3)(7): 78-84$

21. Brakembury PH, Kotowsli J. A comprarative study of the management of ankle sprains. Br J Clin Practice 1983; 37(5): 181-5.

22. Brooks SC, Potter BT, Rainey JB. Treatment for partial tears of the lateral ligament of the ankle: a prospective trial. BMJ 1981;282:606-7.

23. Care D, Craf IL, Howells IB, Shaw PC. Diagnosis and treatment of injury of lateral ligament of the ankle joint. The Lancet $1964: 720$ 3.

24. Cetti $R$, Christensen $\mathbf{S E}$, Corfitzen MT Ruptured tibular ankle ligarment: pliaster or pliton brace? Brit J Sports Med 1984; 18(2): 104-9.

25. Clark A. A double blind trial of low level laser? therapy for soft tissue injury. World Confed. Phys Therapy 11 th Intern Congress Barbican Centre London 28 July.2 Aug 1991: 807-9.

26. Cote DI, Prentice WE, Hooker DN, Shields EW" Comparison of three treatment procedures for minimizing ankle sprain swelling. Physical Therapy 1988; 68(7): 1072-6.

27. Dettori JR, Pearson BD, Basmania CJ, Lednar WM. Early ankle mobilization, part I: The immediate effect on acute, lateral ankle sprains. A randomized clinjcal trial. Military Medicine 1994; $159: 15-20$

28. Dettori JR, Basmania CJ. Early ankle mobiliza tion, Part II: One-year follow up of acute, lateral ankle spraims. A randomized clinical trial. Military Medicine 1994; 159:2014.

29. Eiff MP, Smith AT, Smith GE Early mobilization versus inmobilization in the treatment of latterill ankle sprains. Antrican Journal Sports Medicine $1994 ; 22(1): 83-8$

30. Fremian MAR Treatment of nuptures of the Jateral ligament of the ankle. II Bone Jout Surgery $1965 ; 47 \mathrm{~B}(4): 661-8$.

31. Freman MAR. Instability of the foot after injuries to the lateral ligament of the ankle. J Bone Joint Surgery $1965 ; 47 \mathrm{~B}(4) ; 669 \sim 77$.

32. Gronmark $T_{n}$ Johnsen $O$, Kogstad $O$. Rupture of the lateral ligaments of the ankle: a controlled clinical trial. Injury: the British Journal of Accident Surgery $1980 ; 11: 215-8$.

33. Hedges IR, Anwar RAH. Manigement of ankle spraims. Ann Emerg Med 1980; 9(6): 296-302.

34. Holmer P, Carstensen ND, Merrild UB. Stottestromper kontra stottbind i behandlingen af akutte ankeldistorsioner. (Compression stocking 
wersus bandage in acute ankle spirains) Ugeskr Laeger 1991; 153(6): 430-2.

35. Johannes Ed, Kaulesar Sukul DMKS, Spruit PJ, Putters MM. Controlled trial of a semi-rigid bandage ("scatchwrap") in patients with ankle ligament lesions. Curr Med Res Opin 1993; 13: 154-62.

36. Kleir I, Rixen D, Albring Th, Tiling Th. Funktionelle versus Gipsbehandlung bei der frischen Aussenbandruptur des oberen Sprunggelenks. (Functional treatment versus plaster of Paris treatment in acute ankle sprains) Unfallehirurg 1991, 94: 99-104.

37. Konractsen L, Holmer P, Sondergaard L. Early mobilizing treatment for grade III ankle ligament injuries. Foot Ankle 1991; 12(2): 69-73.

38. Korkala $O$, Rusanen $M$, Jokipif $P$, Kytomaa J, Avikainen V. A prospective study of the treatment of severe tears of the lateral ligament of the ankle. International Orthopaedics $1987 ; 11: 13-7$.

39. Leanderson $I$, Wredmark T. Treatment of acute ankle sprain. Comparison of a semi-rigid ankle brace and compression bandage in 73 patients. Acta Orthop Seand 1995;66(6):529-31.

40. Lelieveld wan DW. Vaerdien af ultralyd og elstimulation ved behandling af distorsioner. (Ultrasound or electrical stimulation in the treatment of ankle sprains) Ugeskr Laeger 1979; 141: $1077-80$.

41. Makuloluwe RTB, Mouzas GL. Ultrasound in the treatment of sprained ankles. Practitioner 1977; 218: 586-8.

42. McGill $\mathrm{SN}$. The effects of pulsed shortwave therapy on lateral ligament sprain of the ankle. $\mathrm{NZ}$ I Physiotherapy 1988; December: 21-4.

43. Michlovitz $S$, Smith $W$, Watkins $M$. Ice and high voltage pulsed stimulation in treatment of acute lateral ankle sprains. J Orthop Sports Phys Ther 1988: 9(9): 301-4.

44. Muller-Larsen $F$, Whetelund JO, Jurik $A G$, Carvalho $A$, Lucht $U$. Comparison of three different treatments for ruptured lateral ankle ligaments. Acta Orthop Scand 1988; 59(4):564-6.

45. Muwanga CL, Quinton DN, Sloan JP, Gillies P, Dove AF. A new treatment of stable lateral ligament injuries of the ankle joint: Injury 1986; 17: $380-2$.

46. Nillsson S. Sprains of the lateral ankle ligaments. An epidemiological and clinical study with reference to different forms of conservative treatment. J Oslo City Hosp 1983; 33: 13-36.
47. OHara $J_{y}$ Valle-Jones $J C_{s}$ Walsh $\mathrm{H}$, OHara $\mathrm{H}_{\text {, }}$

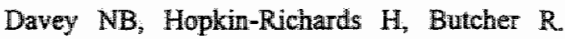
Controlled trial of an ankle support (Malleotrain) in acute ankle injuries. Br J Sports Med 1992; 26(3): $139-42$.

48. Oostendorp RA.B. Functionele instabiliteit na het inversietrauma van de enkel en voet: een effectonderzoek van pleisterbandage versus pleisterbandage gecombineerd met fysiotherapie. (Functional instability after ankle sprains; a trial of taping versus taping and exercise) Geneeskunde en Sport 1987; 20(2): 45-55.

49. Pasila $M$, Visuri $T$, Sundholm A. Pulsating shortwave diathermy: value in treatment of recent ankle and foot sprains. Arch Phys Med Rehab 1978; 59 : $383-6$.

50. Pennington $G M$, Danley $D L$, Sumko $M H$, Bucknell A, Nelson JH. Pulsed, non-thermal, high-frequency electromagnetic energy (diapulse) in the treatment of grade I and grade II ankle sprains. Military Medicine 1993; 2: 101-4.

51. Rucinski TJ, Hooker DN, Prentice WE, Shields $\mathrm{EW}$, Cote-Murray DJ. The effects of intermittent compression on oedema in post acute ankle sprains. JOSPT 1991; 14(2): 65-9.

52. Scotece GG, Guthrie MR. Comparison of three treatment approaches for grade I and II ankle sprains in active duty soldiers. JOSPT 1992; 15(1): 19-23.

53. Sloan $\mathrm{JP}$, Hain $R$, Pownall R. Clinical benefits of early cold therapy in accident and emergency following ankle sprain. Arch Emergency Med $1989 ; 6: 1-6$.

54. Sommer von HM, Schreiber H. Die fruh konservative Therapie der frischen fibularen Kapsel-band-ruptur aus sozial-ökonomischer sicht. (Early functional conservative therapy of a fresh fibular rupture of the capsular ligament from a socioecononical viewpoint). Spontverl Sportschad $1993 ; 7: 40-6$.

55. Wester $\mathrm{U}$, Jespersen $\mathrm{SM}$, Nielsen $\mathrm{KD}$, Neumann L. Wobble board training after partial ankle sprains of lateral ligaments of the ankle: a prospective randomized study JOSPT 1996; 5 : 332-6.

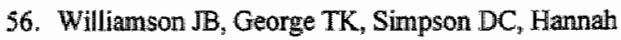
$B$, Bradbury $E$. Ultrasound in the treatment of ankle sprains. Injury 1986; 17: 176-8.

57. Zeegers A VCM. Het supinatieletsel van de enkel. Dissertation, Rotterdam, 1995.

58. Zwipp $\mathrm{H}_{3}$ Schievink B. Primary orthotic treatment of ruptured ankle ligaments: a recommended 
procedure. Prosthetics and Orthatics International 1992; 16: 49-56.

59. Verhagen AP, Vet HCW de, Bie RA de, Kessels AGH, Boers M, Knipschild PG. Balmeotherapy and Quality Assessment. The interobserver reliability of the Maastricht criteria list and the need for blinded quality assessment. J Clü Epid 1998 (In Press).

60. Heijden GMMG van der, Wind DAWM van der, Kleijnen J; Koes BW, Bouter LM, Knipschild PO. The afficacy of corticosteroid injections for shoulder complaints: a blinded systematic review. $\mathrm{J}$ Clin Epid 1995; 48 : $691-704$. 


\title{
3 EFFICACY OF 904 NMLASER THERAPY N MUSCULOSKEI ETAL DISORDERS: A SYSTEMATIC REVIEW
}

\author{
Robert A de Bie, MA, PT \\ Arianne P Verhagen, Msc, $\mathrm{PT}^{\mathrm{I}}$ \\ Anton F Lenssen, $\mathrm{PT}^{2}$ \\ Henrica $C W$ de Vet, $\mathrm{PhD}^{1}$ \\ Frans $\mathrm{AJM}$ van den Wildenberg, $\mathrm{MD}, \mathrm{PhD}^{3}$ \\ Gauke Kootstra, Phd, $\mathrm{MD}^{3}$ \\ Paul G Knipschild, MD, PhD \\ "Department of Epidemiology, Maastricht University \\ ${ }^{2}$ Department of Physiotherapy, University Hospital of Maastricht \\ ${ }^{3}$ Department of General Surgery, University Hospital of Maastricht
}

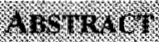

Objective: This systematic review summarises the efficacy of $904 \mathrm{~nm}$ low level laser therapy (LT) in musculoskeletal disorders.

Method: In order to retrieve randomised trials computer aided searches of databases and of bibliographic indexes were performed. Furthermore, congress reports, reviews and handbooks were checked for relevant citations. Subsequently, all retrieved studies were scored on methodological quality.

Results: We found 25 studies that investigated the effects of $904 \mathrm{~nm}$ LT versus placebo or any other intervention, in subjects with a condition for which LT was thought a feasible intervention. Of these, 21 fulfilled our entry criteria, and were assessed in a blinded manner on methodological criteria. Overall, study quality ranged from poor to reasonable. Classification of the material into diseases studied, yielded no clear evidence for the efficacy of LT, except perhaps for knee problems and myofascial pain.

Conclusion: We conclude that $904 \mathrm{~nm} \mathrm{LT}$ does not seem to be efficacious in the treatment of musculoskeletal disorders, but that further and improved research is needed to shed more light on its efficacy.

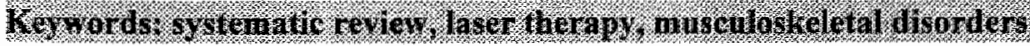




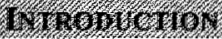

Laser therapy (LT) is a very young treatment modality. Medical lasers were first introduced in the early 1960 's. Favourable results in surgery on humans were reported around 1965. 1.2 About 15 years later the first reports on $\mathrm{LT}$ in physiotherapy ${ }^{3}$ and in acupuncture ${ }^{4}$ appeared. The first randomised clinical trials were published in 1981 by Gallachi et al. ${ }^{5}$ and Lewith et al. ${ }^{6}$ Gallachi described the effects of LT in the treatment of cervical and lumbar pain, whereas Lewith conducted a randomised trial to evaluate the effect of infrared stimulation of local trigger points on the pain caused by cervical osteoarthrosis.

In the treatment of musculoskeletal disorders, lasers with varying wavelengths are used, mostly ranging from 632 to $904 \mathrm{~nm}$. The use of LT has increased rapidly over the last few years, despite the lack of adequate insights into the biological working mechanisms and the extent of its effects.

The physical properties of the interaction between laser light and tissue can be divided into two processes; absorption and scattering. Absorption can be seen as the transformation of light energy into another form of energy, ultimately resulting in warmth dissipation. Absorption of laser light occurs mainly at a molecular level where three mechanisms can be distinguished. Either i) atoms are excited to higher modes of oscillation or ii) electron bonds are excited within the biomolecule or iii) rotation of (parts of) the biomolecule takes place." Scattering, due to differing relative refractive indices of the various cellular substances and molecules, may be defined as a change in the direction of light propagation. Both absorption and scattering are wavelength dependent, and result in the loss of laser power into the irradiated tissue.

The aforementioned physical properties of laser irradiation have led to a series of theories, in which the term biostimulation occurs predominantly. During the past 15 years bio- stimulative effects of $\mathrm{LT}$ have been described by several authors. Biostimulation refers to the application of electromagnetic energy by $\mathrm{LT}$ to body tissues, supposedly influencing all kinds of cell functions. ${ }^{8,910}$ The effects are thought to consist of stimulation or inhibition of biochemical, physiological and proliferative activities. The magnitude of the effect is reported to be dependent on wavelength, dosage and dose-intensity of $L T$. ${ }^{11}$

The "cellular communication" theory, which tries to explain the bio-effectivity of LT claims that, in case of an impairment or disorder, the energy state of a cell is changed, consequently altering the electromagnetic communication between cells. LT is thought to influence this communication in a positive way. ${ }^{7,12}$ The "photochemical theory" offers an alternative explanation. The absorption of laser light takes place in tissue chromophores (photo acceptors). These chromophores may either be enzymes, membrane molecules or any other cellular or extracellular substances. Activation of these chromophores by LT is considered responsible for the postulated bioeffects. ${ }^{13}$

Neither theory has been thoroughly confirmed in research and the supposed underlying mechanism remains unclear. Moreover, recent research with $904 \mathrm{~nm}$ laser on tissue samples has failed to show any effects on cell metabolism, and hence has not provided corroborative evidence. ${ }^{14}$ The lack of a convincing biological basis that explains the clinical effects induced by LT, serves to maintain the conflicts about proper dosage and treatment indications. Musculoskeletal disorders are thought to be influenced positively by LT in five main areas; analgesic effects, anti-inflammatory effects, nerve regeneration, regeneration of muscular tissues and of bone tissues. ${ }^{12,13}$ Thus, a further analysis of the potential effects of LT on each of these areas seems imperative.

We decided to perform a systematic review to evaluate the efficacy of $904 \mathrm{~nm}$ LT. 


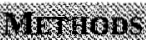

Trials on $904 \mathrm{~nm}$ low level LT were identified by Medline and Embase searches (both up to 1996) and by checking the Database of the Cochrane 'Rehabilitation \& Related Therapies Field" at Maastricht University, the Netherlands. Keywords used for the intervention under study were laser, low level laser therapy, infra red, light therapy in combination with rehabilitation, exercise therapy, physiotherapy and physical therapy.

Keywords used to describe the design were: controlled trials, experiments, clinical trials, randomised and evaluation studies. Additionally, Current Contents and Physiotherapy Index, reviews, congress reports, and handbooks on LT were checked. Retrieved references were followed-up by citation tracking. Papers published in English, French, German, Dutch, Spanish, Italian, Norwegian, Swedish and Damish were eligible for inclusion. Abstracts and unpublished studies were not included.

The selected studies had to fulfil the following criteria for inclusion in the review. The subjects in the study had to have a condition for which LT was thought a feasible treatment option and this had to be contrasted with placebo, no treatment or other interventions. The treatment regimen had to consist of 904 nm LT and the study design had to be a randomised clinical trial. This design is considered the paradigm for intervention studies because of its potential to provide a valid assessment of the efficacy of an intervention. 15,16

The papers eligible for reviewing were blinded for author(s), journal and references and the lay-out of the original papers was changed. They were distributed to two reviewers (APV and AFL) who independently assessed the quality of the studies. They tried to reach consensus in a subsequent meeting on the items, on which they disagreed. If consensus could not be reached, a third (not blinded) reviewer (RAB) made the final decision.

Table 1 shows the criteria used for assessing the methodological quality of the trials. The list was originally designed by Ter Riet et al ${ }_{\text {., }}$ " and modified over the years by Koes et al. ${ }^{18}$ Van der Heijden et al. ${ }^{19}$ and Assendelft et al. ${ }^{20}$ It is based on generally accepted principles of intervention research. ${ }^{15,16}$ The criteria list was adapted for LT, with respect to the intervention, laser parameters, and relevant outcome measures. Studies could earn points for methodological quality in five categories. They dealt with study population, interventions, blinding, outcome and data presentation and analysis. A maximum score of 100 points could be obtained. With respect to the evidence on efficacy of LT, a study was considered 'positive' if its author(s) concluded that laser treatment was more effective than the reference treatment. This usually corresponded with a statistical signi-ficant difference between treatments. However, a number of studies also reached this conclusion on pre-post group comparisons. In the results section we corrected for this. A study was labelled 'negative' if no difference between the study treatments was reported or if the reference treatment showed better results.

\section{1.th}

Twenty-five trials ${ }^{21-45}$ were identified that used some form of randomisation and compared $904 \mathrm{~nm}$ LT with a different intervention or placebo therapy. Of these, four papers were excluded from further reviewing; three were controlled clinical trials but not randomised ${ }^{42,43,44}$ and one trial used healthy individuals, instead of patients. ${ }^{45}$ One author ${ }^{40,41}$ presented different arms of the same trial in separate articles. Since the methodology was reported differently as well, we describe the results of each arm (article) separately. The methodological characteristics of the remaining 21 trials are presented in Table 2, ranked according to their methodological score. 
Table 1: Criteria for assessing methodological quality in randomised clinical trials of low level laser therapy.

\section{(6.10.7.7.}

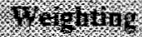

Study population (total points $=49$ )

$\begin{array}{llr}\text { A } & \text { Homogeneity } & 4 \\ \text { B } & \text { Randomisation procedure mentioned } & 10 \\ & \text { Concealed method of randomisation } & 10 \\ \text { C } & \text { Comparability of rellevant baseline characteristics } & 6 \\ \text { D } & \text { Numbers of patients } & 9 \\ \text { E } & \text { Dropouts described for each study group separately } & 7 \\ \text { F } & \text { Loss to follow up not leading to bias } & 3\end{array}$

Intervention (total points $=14$ )

G Intervention adequately described and performed $\quad 12$

H Co-interventions avoided or equal in study groups 2

Blinding (total points $=18$ )

I $\quad$ Patients blinded $\quad 6$

J Therapist blinded $\quad 6$

K Observer blinded

Outcome (total points=12)

L $\quad$ Adequate outcome measures 5

M Adequate follow up period 5

N Description of side effects 2

Data presentation and analysis (total points $=7$ )

O Mean or frequencies of most important outcome measures presented for each 3 group 1

P Intention to treat analysis

Q Adequate correction for baseline differences of drop outs 3

* further details given in appendix

The methodological score ranged from 6 to 65 points. Seven out of the 21 trials used a crossover design. ${ }^{21,26-29,36,38}$ The descriptions of inclusion and exclusion criteria $(A)$, the intervention $(G)$ and blinding of the patient, therapist and/or observer (I, J, K) were in general satisfactory. The descriptions of prognostic comparability (C), drop outs (E), co-interventions $(\mathrm{H})$ and side effects $(\mathrm{N})$ were rather disappointing.

Quite a number of studies mentioned that the allocation procedure was randomised, but failed to mention how this was done or if the method of randomisation was concealed.

Some studies showed obvious flaws in their design leading to bias. Vasseljen ${ }^{41}$ mentioned that patients and physiotherapists were 'fully aware of the treatment being given', whereas in the study of England et al. ${ }^{25}$ the therapist was not blinded 'for reasons of safety and 
practicality". Rather large drop out rates were reported in the studies of Flöter et al. ${ }^{25}$ and Lucas et al. ${ }^{32}$ where more than $15 \%$ and $27 \%$ of the patients dropped out, respectively.

Table 2: Methodological item scores per study

\begin{tabular}{|c|c|c|c|c|c|c|c|c|c|c|c|c|c|c|c|c|c|c|}
\hline 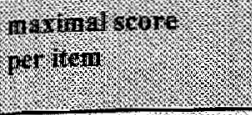 & 4 & $\frac{1}{20}$ & 6 & 17 & $E^{2}$ & $1 /$ & 10 & 17 & 8 & 1 & 18 & 4 & 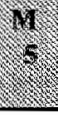 & $\mathrm{N}^{2}$ & (a) & 1 & 9 & 100 \\
\hline Olavi, $1988^{36}$ & & & & & & & 5 & & & & & & & & 1 & & & 6 \\
\hline Beard, $1990^{21}$ & & & & & & & 8 & & & & & & 2 & & & & & 10 \\
\hline Gobele, $1986^{2}$ ? & & & & & & & 2 & & 4 & 4 & & & & & 1 & & & 11 \\
\hline Dolan, $1988^{\circ}$ & & & & & & & 8 & & & 4 & & & & & 1 & & & 13 \\
\hline Meler, $1988^{\circ}$ & 4 & & 2 & 3 & & & 6 & & & & & & & & & & & 15 \\
\hline Bithar, $1989^{2}$ & & & & & & & 6 & 2 & 4 & & 4 & & & 2 & & & & 18 \\
\hline Longo, $1988^{\circ}$ & 2 & & 2 & & & & 4 & 2 & & & 4 & & 5 & & & & & 19 \\
\hline Seichert $1987^{\circ}$ & & & & & & & 9 & & 4 & & & & & 2 & 3 & 1 & & 19 \\
\hline Jensen, $1987^{2}$ ? & 2 & & & & 5 & & 10 & & 4 & 4 & & & & & & & & 25 \\
\hline England, $1989^{\text {th }}$ & 2 & & & 3 & & & 9 & & 4 & & 4. & 2 & & & 1 & & & 25 \\
\hline Ceccherelli, 1989 ? & 4 & & & 6 & & & 6 & & 4 & 4 & & & 5 & & 1 & & & 30 \\
\hline Fioter $1988^{\circ 6}$ & & 10 & 2. & & & & $\$ 0$ & & 4 & 4 & & 1 & & & & & & 31 \\
\hline Nivbrant, $1989^{\prime}$ & 2 & 10 & & 3 & 1 & & 10 & & 4 & 4 & & 3 & 2 & & 1 & & & 40 \\
\hline Lucas $1995^{32}$ & 2 & & & 9 & 2 & & 8 & 2 & 4 & 4 & 4 & 2 & & & 3 & 1 & & 41 \\
\hline Hansen, $1990^{\circ}$ & 4 & 10 & & & & & 7 & & 6 & 6 & 6 & 3 & & 2 & & & & 44 \\
\hline Rogvi, $1991^{3}$ & 4 & 10 & & 9 & 1 & & 7 & 2 & & 4 & 4 & 2 & 5 & & & & & 48 \\
\hline Siebert $1986^{\circ}$ & 2 & 10 & 2 & 9 & & & 10 & 2 & 4 & & 4 & 5 & 5 & & & & & 53 \\
\hline Lundeberg, $1987^{31}$ & 4 & 20 & & & & & 8 & & 4 & 4 & 4 & 4 & 5 & & 1 & & & 54 \\
\hline Vasseljen 1992 & 4 & 10 & & 9 & 7 & 3 & 10 & 2 & & & & & 5 & & 3 & 1 & & 54 \\
\hline Klein, 9990 & 4 & 10 & & 9 & & & 10 & 2 & 4 & 4 & 4 & 5 & & 2 & 3 & 1 & & 58 \\
\hline Vasselien.1992 4 & 4 & 10 & & 9 & 5 & 3 & 10 & 2. & 4. & 4 & & 5 & 5 & & 3 & 1 & & 65 \\
\hline
\end{tabular}

In correct allocation procedures were suspected in the studies by Longo et al. ${ }^{31}$ and Dolan et al. ${ }^{24}$ In the latter study the person who was responsible for the randomisation had experienced 'serious ethical problems' when he had randomised patients to the control group. This study also allowed for many cointerventions and groups were prognostically not comparable. Taken together the reviewed studies used 70 measures of effect in total, of which 30 were related to pain and 3 to the use of analgesics. Five studies reported on range of motion (ROM) and five on influence of LT on activities of daylife. Table 3 gives a short description of the study design, participants, interventions and outcome measures. Additional measures of outcome were very diverse, and made an estimate of the overall effect of LT difficult. The studies are arranged in alphabetical order by first author.

As can be seen from Table 3 , quite a number of outcome measures per study has been used. However, comparison of outcomes between studies was hampered by incomparability of patient groups or diseases studied. 


\section{Table 3: Description of studies and outcomes}

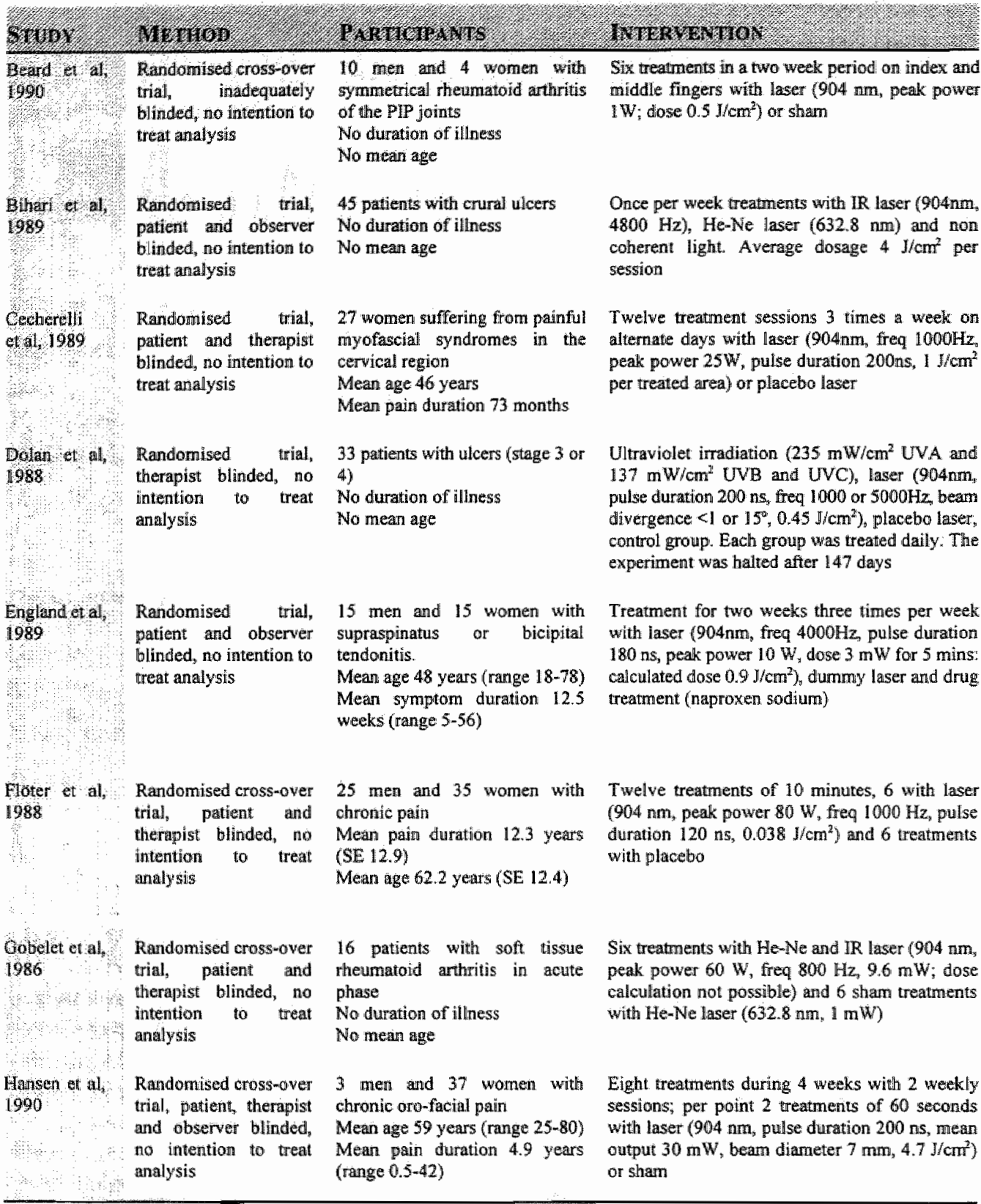




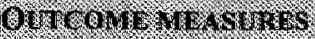

Measured at initial assessment and after 2 and 4 weeks. Mean differences between laser and shim not given, only p-kalues;

- joint range $(p=1.02)$

- joint size $(p=0.15)$

- joint tenderness (measurement failed)

Measured at initial assessment, last measurement at 9 months, other measurements unclear. Ratios given on;

- wound healing; effective/not effective (IR laser 14/1, He-Ne lase 14/1, light 8/5)

Measured at initiall assessment, at four weeks and at three months.

- At 4 weeks mean difference between laser and placebo $12.2(p=0.008)$

Measured at initial assessment and every week for 22 weeks:

- wound surface area; impossible to capture data

Measured at initial assessment and after 2 weeks: Mean differences between laser and dummy laser on:

- range of mowement; Ext $6^{\circ}(p=0.005)$, Flex $15^{\circ}(p=0.005)$, Abduction $20^{\circ}(p=0.005)$

- pair (VAS) $2.5 \mathrm{~cm}(p=0.001)$

- stiffness (VAS) $1 \mathrm{~cm}(\mathrm{P}=0.05)$

- function (VAS) $1.5 \mathrm{~cm}(\mathrm{p}=0.05)$

- mobility (VAS) $2 \mathrm{~cm}(\mathrm{p}=0.005)$

Measured at initial assessment, and after 6 and 12 treatments. Mean differences between laser and placebo after 12 treatments on;

- pain intensity (VAS) $1.07 \mathrm{~cm}$

* mood (VAS) $0.46 \mathrm{~cm}$

- Juration of pain episodes, no data

- numbliber of pain episodes; no data

Measured at initial assessment, and after 6 and 12 treatments. Mean differences at 12 treatments on:

- combined index for pain, mobility, sports capacity and work; $11.6(p=0.005)$

Measured during every treatment session.

pain intensity; no data

- analgesic consumption; no data

- influence of pain during ADL; no data

- paín duration; no data

\section{Notits}

No effect

Data do not allow for pooling

Positive effect

Data do not allow for pooling

Positive effect

Positive effect

Incorrect allocation procedure, prognostically inhomogeneous groups, many co-interventions Data do not allow for pooling

Positive effect

Data do not allow for pooling

Positive effect

Selective drop out rate of $15 \%$

Data do not allow for pooling

Positive effect

Pre-post conparison of datit Data do not allow for poroling

No effect

Data do not allow for pooling 


\begin{tabular}{|c|c|c|c|}
\hline $8 x+x y$ & 66 140 & 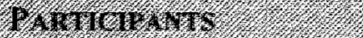 & 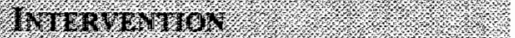 \\
\hline Mrrat al & $\begin{array}{l}\text { Randomiged oross-over } \\
\text { trial, patient and } \\
\text { therapist blinded, no } \\
\text { interition lo treat } \\
\text { andilysils }\end{array}$ & $\begin{array}{l}3 \text { men and } 26 \text { wornien with } \\
\text { arthrosis of the knee } \\
\text { Meari age } 72 \text { years (range } 55-82 \text { ) } \\
\text { No duration of illness }\end{array}$ & 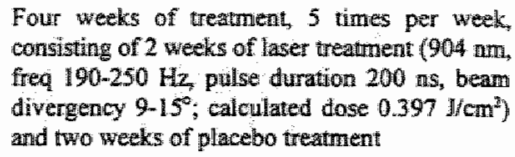 \\
\hline 1990 & $\begin{array}{l}\text { Randornised trial } \\
\text { patients therapist and } \\
\text { observer blinded, no in } \\
\text { lention to treat analysiss }\end{array}$ & $\begin{array}{l}15 \text { women and } 5 \text { men with } \\
\text { chronic low back pain } \\
\text { Mean age } 42 \text { years ( } S E 9 \text { ) } \\
\text { Mean pain duration } 8.7 \text { years } \\
\text { (SE } 7 \text { ) }\end{array}$ & $\begin{array}{l}\text { Twelwe treatments for } 4 \text { weeks, } 3 \text { times per week } \\
\text { with laser }(904 \mathrm{~nm}, \text { freq } 1000 \mathrm{~Hz} \text {, pulse pause } \\
200 \mathrm{ng} \text {, dose } 1.3 \mathrm{~J} / \mathrm{cm}^{2}, 20 \text { minutes per area) or } \\
\text { placebo laser }\end{array}$ \\
\hline 1988 & $\begin{array}{l}\text { Randomised trial, } \\
\text { observer blinded, no in } \\
\text { tention to treat analysis }\end{array}$ & $\begin{array}{l}120 \text { patients with acute lumbago } \\
\text { Age range }(40-65) \text { years } \\
\text { No duration of illness }\end{array}$ & $\begin{array}{l}\text { Laser ( } 904 \mathrm{~nm} \text {, freq } 3000 \mathrm{~Hz} \text {, pulse duration } 200 \\
\text { ns, peak power } 72 \mathrm{~W} \text {; dose calculation not } \\
\text { possible) placebo laser or } 10,600 \mathrm{~nm} \text { laser (freq } \\
5500 \mathrm{~Hz}, 30 \% \text { duty cycle, peak power } 150 \mathrm{~W} \text {, } \\
\text { divergence } 1.5 \text { rad) }\end{array}$ \\
\hline $\begin{array}{l}1095 \\
\text { at al }\end{array}$ & $\begin{array}{l}\text { Randomised triall, } \\
\text { patient, therapist and } \\
\text { observer blinded, no in- } \\
\text { tention to treat analysis }\end{array}$ & $\begin{array}{l}39 \text { patients with crural ulcers } \\
\text { (stage } 3 \text { ) } \\
\text { Mean age } 85 \text { years } \\
\text { No duration of illness }\end{array}$ & $\begin{array}{l}\text { For a maximum of } 6 \text { weeks, } 5 \text { treaments a week } \\
\text { with laser ( } 904 \mathrm{~nm} \text {, peak power } 12 \times 70 \mathrm{~W} \text {, freq } \\
830 \mathrm{~Hz} \text {, pulse duration } 150 \mathrm{~ns} \text {, mean power } 8 \\
\left.\text { m } 125,12 \mathrm{sec} \text {, dose } 1 \mathrm{~J} / \mathrm{cm}^{2}\right) \text {, placebo treatment, } \\
\text { control treatment }\end{array}$ \\
\hline $\begin{array}{l}\text { Uundeberg } \\
\text { et at, } 1987 \text {. }\end{array}$ & $\begin{array}{l}\text { Randomised trial, } \\
\text { patient, therapist and } \\
\text { observer blinded, no in- } \\
\text { tention to treat analysis }\end{array}$ & $\begin{array}{l}31 \text { men and } 26 \text { women with } \\
\text { tennis elbow } \\
\text { Mean age } 43 \text { years (range } 25-62 \text { ) } \\
\text { No duration of illness }\end{array}$ & $\begin{array}{l}\text { Ten treatments, } 2 \text { per week with a duration of } 300 \\
\text { sec with IR-Laser }(940 \mathrm{~nm} \text {, freq } 73 \mathrm{~Hz} \text {, dose } 0.07 \\
\left.\text { mW; cillculated dose } 0.021 \mathrm{~J} / \mathrm{cm}^{2}\right) \text {, He-Ne laser } \\
(632.8 \mathrm{~nm} \text {, peak power } 1.56 \mathrm{~mW} \text { ) or no treatment }\end{array}$ \\
\hline $\begin{array}{l}\text { Meler of a } \\
1988\end{array}$ & $\begin{array}{l}\text { Randomised trial, not } \\
\text { blinded no intention to } \\
\text { treat analysis }\end{array}$ & $\begin{array}{l}30 \text { men and } 28 \text { women with } \\
\text { infrapatellar tendinitis } \\
\text { Mean age } 34 \text { years } \\
42 \text { men and } 10 \text { women with wehil- } \\
\text { les tendinitis } \\
\text { Mean age } 38 \text { years } \\
\text { No duration of illness }\end{array}$ & $\begin{array}{l}12 \text { treatments, for } 3 \text { weeks, } 4 \text { times per week with } \\
\text { laser }(632.8 \mathrm{~mm} \text {, peak power } 6 \mathrm{~W}+904 \mathrm{~nm} \text {, peal } \\
\text { power } 7 \mathrm{~W} \text {, mean power } 25 \mathrm{~mW} \text {, pulse duration } \\
180 \mathrm{msec} \text {; callewlated dose } 1.19 \mathrm{~J} / \mathrm{cm} \mathrm{m}^{2} \text { ) or sham } \\
(632.8 \mathrm{~nm} \text {, peal power } 6 \mathrm{~W}) \text {. Treatment } \\
\text { prolonged when not improved }\end{array}$ \\
\hline $\begin{array}{l}\text { Nivbrant } \\
\text { ot al } 1089\end{array}$ & $\begin{array}{l}\text { Rutidomised unial, } \\
\text { patient and therapist } \\
\text { blinded, no intention to } \\
\text { treat analysis }\end{array}$ & $\begin{array}{l}30 \text { patients with arthrosis: of the } \\
\text { knee } \\
\text { Mean age } 67 \text { years } \\
\text { no duration of illness }\end{array}$ & $\begin{array}{l}\text { Six treatments, once a week with haser ( } 904 \mathrm{~mm} \text {, } \\
\text { freq } 5000 \mathrm{~Hz} \text { mean output } 4 \mathrm{~mW} \text {, beam diameter } \\
0.07 \mathrm{~cm}^{2} \text {, dose } 0.7 \mathrm{~J} / \text { point) or placebo laser }\end{array}$ \\
\hline
\end{tabular}




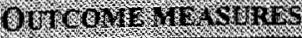

Measured a initial asessment, after 2 and after 4 weeks:

- pain during rest, period index, no data

- pain during movement no data

No effect

- analgesic consumption; no data

Data do not allow tor pooling

Measured at initial treatment and after treatment. Mean differences berween laser and placebo

- range of motion; differences in degrees

- rotation $0.1^{\circ}$, flexion $3.3^{\circ}$, extension $0.1^{\circ}$, lat flexion $02^{\circ}$

- isometric torque differences in foot pounds

- isometric rotation $0.1^{\text {s }}$ isometric flexion $7.5^{\text {a }}$ isometric extension $3.3^{\text {tho }}$,

- isometric lat. flexion $3.2^{\circ}$

- maximum velocity differences in degreesisec

- rotation 11 3; flexion 4.9; extension 1.2 ; lat. flexion 9.5

- pain (VAS) difference $0.4 \mathrm{~cm}$

- disability (VAS) difference $0.7 \mathrm{~cm}$

Measured at initial treatment, after 3 and 5 treatments, 1 and 6 months, after 1 year

- combined measure of effect on pain, antalgic posture and functional himitation; data unclear

- rellapses; no data

Measured at initial assessment and once a week

- wound surface area difference in \% (pre-post comparison);

- laser $66.5 \% \pm(9.6) ;$ control $19.6 \% \pm(22.5)$; placebo $6.8 \% \pm(37.2)$

- wound healing process; no data

Measured at initial treatment, after treatment series and after 3 months mean differences between groups

- pair (VAS) $0.4 \mathrm{~cm}$

- pain on resisted wrist dorsiflexion (VAS) $0 \mathrm{~cm}$

- pain on weight test (VAS) $0.1 \mathrm{~cm}$

- grip strength $3.3 \mathrm{~cm}$

- differences in nerve conduction

- latency $0 \mathrm{msec}$ amplitude $3 \mathrm{~V}$; temperature $1^{\circ} \mathrm{C}$

Measured at intial assessment and every treament week; combined index on pain and mobility.

Ratios on:

- knee after 3 weeks

- laser cured hot cured $17 / 8$; placobo cured/not curet $11 / 14$

- achilles after 3 weeks

- laser cured/not cured $16 / 9$; placebo $7 / 18$

- re-uptake of sports: knee

- laser 62\%, placebo; no data

- re-uptake of sports: achilles

- laser $70 \%$; placebo no data

- total improvement; no diata

Measured at iminal assessment, after treatment series; follow up after 1 week and after 4 weeks Mean differences between laser and placebo after treatment series, 1 week and 4 weeks

- pair at rest (VAS) $1.3 \mathrm{~cm}_{4} 1.3 \mathrm{~cm}$ and $1.2 \mathrm{~cm}$

* pain during movement (VAS) $1 \mathrm{~cm}, 0.8 \mathrm{~cm}$ and $0.7 \mathrm{~cm}$

" ability to walk (VAS) $1.2 \mathrm{~cm}, 1.1 \mathrm{~cm}, 0.2 \mathrm{~cm}$

- stiffness; no data;

" sleep; no data

- analgesic consumption; no dati

- general improvement, no data
No effect

Cominterwention: wetive axereise programme for both groups. Pre-post comparison of datal

Positive effect

Incorrect allocation procedure suspected

Data do not allow for pooling

Positive effect

Selective drop ont rate of $27 \%$

No effect

Positive effect

Data do not tllow for pooling

Pre-post comparisotu of data
Positive effect 


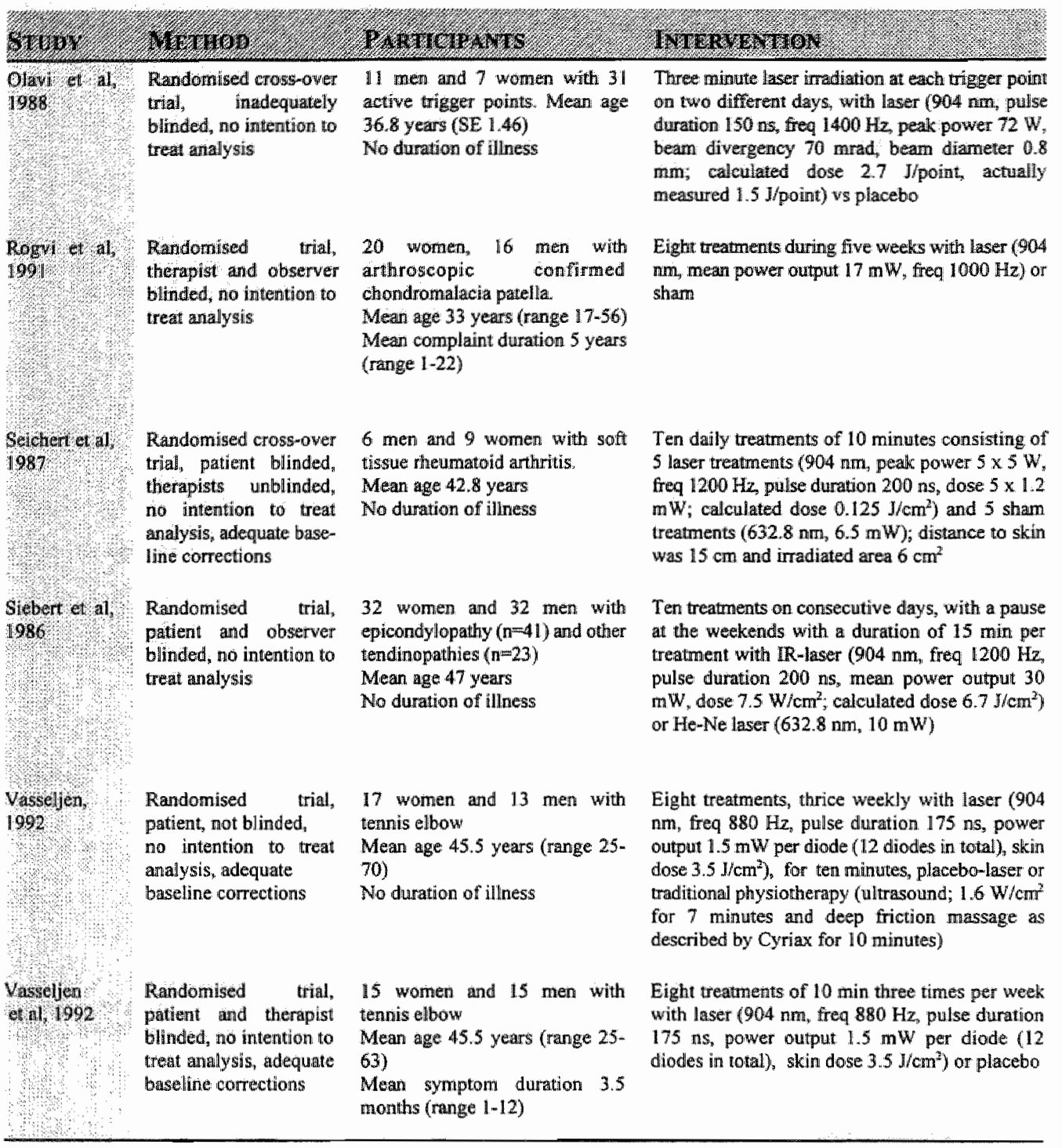




\section{6)}

Measired directly after last treatrnent; and at 15 mimutes after last treatment

- pain threshold $\left(\mathrm{kg} / \mathrm{cm}^{2}\right)$, mean differences between laser and placebo

- 0.31 affiter treatment; 0.91 after 15 minutes

\section{Tintiss}

Positive effec

Data do not allow for pooling
Measured at initial assessment and after the treament series; mean differences between laser and placebo

* pain intensity (VAS): $1 \mathrm{~cm}$

- pain location no data

- disability sicore; 1 point out of 20

- overall effect

- laser cured/not cured $10 / 9 ;$ placebo $3 / 14$

Measured at initjal assessment, after 5 and after 10 treatments

Mean differences between laser and placebo after $\$$ and 10 treatments respectively:

- pain during rest (VAS) $0.1 \mathrm{~cm}_{4} 0 \mathrm{~cm}$

- pain auring movement (VAS) $0 \mathrm{~cm}, 0.2 \mathrm{~cm}$

- presstre pain (VAS) $0 \mathrm{~cm}, 0 \mathrm{~cm}$

Measured at initial treatment, tenth treatment and 2 weeks after conclusion of treatment. Mean differences between laser and placebo on a $0-3$ point scale on treatment 10 and after two weeks; - pain at rest; 0,0 points

- pain during movement; $0,0.3$ points

- pressure pain; $0.1,0.1$ points

- range of movement; no data

- sensations during laser therapys mo data

Measured at initial treatment, at the end of treatment period, at 4 weeks and 5 im 6 months after treatment. Mean differences between laser and physiotherapy at end of treatment and at 4 weeks - grip strength (bar) $0.05,0.1$

- weight test $(\mathrm{kg}) 0.3,0.1$

- range of motion; no data

- pain intensity (VAS) $1.2 \mathrm{~cm}, 1.1 \mathrm{~cm}$

- general improvernent; no data

Measured at initial treatment, at end of treatment amd at 4 weeks. Mean differences between laser and placebo at end of treatment and at 4 weeks

- grip strength (bar) $0.05,0.1$

- weight test (kg) $0.3,0.5$

- range of motion (degrees) $3^{\circ}, 1^{\circ}$

- pain intensity (VAS) $0.2 \mathrm{~cm}, 0.4 \mathrm{~cm}$

- general improvementi: no data
Positive effect, not significant $10 \%$ drop out rate

Data do not allow for pooling

No effect

Pre-post comparison of data Data do not allow for poolling

No effect

Data do not allow for pooling

Positive effect

Patients and therapists were fully aware of treatment given Data do not allow for pooting Many co-interventions

No effret

Data do non allow for pooling 
As can be seen 904 nm laser was used for the treatment of various diseases.

Three studies reported on the efficacy of LT in theumatoid arthritis, ${ }^{2127,38}$ of which two studies reported no effect and only Gobelet et $a^{21}{ }^{21}$ found a positive effect using a pre-post comparison of the data. No between groups effect was present.

Two out of three studies ${ }^{23,26}$ reported positive effects regarding the efficacy of $\mathrm{LT}$ on myofascial pain; the other study ${ }^{28}$ reported negative effects. The positive study by Floter et al. ${ }^{26}$ was hampered by a drop out rate of $15 \%$.

Four studies ${ }^{24,34,35,37}$ reported on the efficacy of LT in knee problems. Nivbrant et $a^{35}$ and Rogvi et al. ${ }^{37}$ found a positive, although not significiant, trend towards efficacy, whereas Jenssen et all. ${ }^{24}$ found no effect. The positive results from Meier et al. ${ }^{34}$ were due to a prepost comparison of the data, and disappeared in a between groups analysis.

Oniy the study by Olavi et al ${ }^{36}$ reported on the efficacy of LT on trigger points and showed favourable results, but this study was hampered by a rather large amount of noninformativeness (see Table 2).
Three studies ${ }^{2,24,32}$ reported on efficacy of LT in the treatment of (pressure) ulcers. Although all three studies were positive, no firm conclusions about efficacy could be drawn here. The positive trend noted by Bihari et al. ${ }^{22}$ was due to an incorrect analysis procedure, whereas the positive study by Dollan et al. ${ }^{24}$ was hampered by an incorrect allocation procedure, many co-interventions and prognostically incomparable groups. The positive study by Lucas et al. ${ }^{3.2}$ was flawed by a drop out rate of $27 \%$.

Five studies reported on the efficacy of LT in tennis elbow ${ }^{33,39-41}$ or tendonitis. ${ }^{25}$ The study on tendonitis ${ }^{25}$ and one study on tennis elbow ${ }^{40}$ reported positive results, whereas the remainder noted no effects.

Finally, two studies reported on the efficacy of LT in low back pain. ${ }^{30,31}$ Klein et al. ${ }^{30}$ observed no effect but used a pre-post comparison analysis procedure, whereas Longo et al. ${ }^{\sharp 1}$ found an effect but an incorrect allocation procedure was suspected in this study.

Table 4 summarizes the available evidence per disease. As can be seen from this table there is no apparent disease in which LT excels in efficacy.

Table 4: Summary of the results of the review per disease

\begin{tabular}{|c|c|c|}
\hline 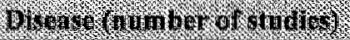 & (4) & 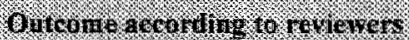 \\
\hline The umatoud antiritis $(\mathrm{n}-3)$ & $+21,-2 \pi,-3$ & - \\
\hline myonascial pan $(\mathrm{n}=3)$ & $+^{29},+26,-26$ & $+9,+9$ \\
\hline lanee problens $(n-4)$ & $4^{35},+^{37},+^{34},-{ }^{34}$ &,,++-9 \\
\hline trogerpoints $(n-1)$ & & (19) \\
\hline pressure ulcers $(\mathrm{n} 3)$ & $++^{22},+24,+32$ & \\
\hline tonn elbov $\left(\mathrm{n}^{-4}\right)$ & 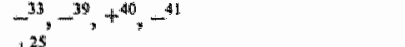 & $\begin{array}{l}-1,-,-\infty \\
+90\end{array}$ \\
\hline low buack pain $\left(\mathrm{n}^{-2} \mathrm{2}\right)$ & $+30-31$ & - - - \\
\hline
\end{tabular}

Pre-post comparisons are recalculated as between comparisons.

Superscript numbers identify the study, where $==$ not effective, $+=$ effective and $=$ undecided.

identifies studies with a quality score of less than 40 points. 
Studies reporting efficacy (according to the authors) had used on average dose of 1.3 $\mathrm{J} / \mathrm{cm}^{2}$, whereas studies reporting no results had used an average dose of $2.1 \mathrm{~J} / \mathrm{cm}^{2}$. The use of different dosages per study could not be related to the year of publication of the study.

However, it is interesting to see that the methodological quality of the studies seems to be increasing over time (see Figure 1).

Figure 1: Methodological score versus publication year

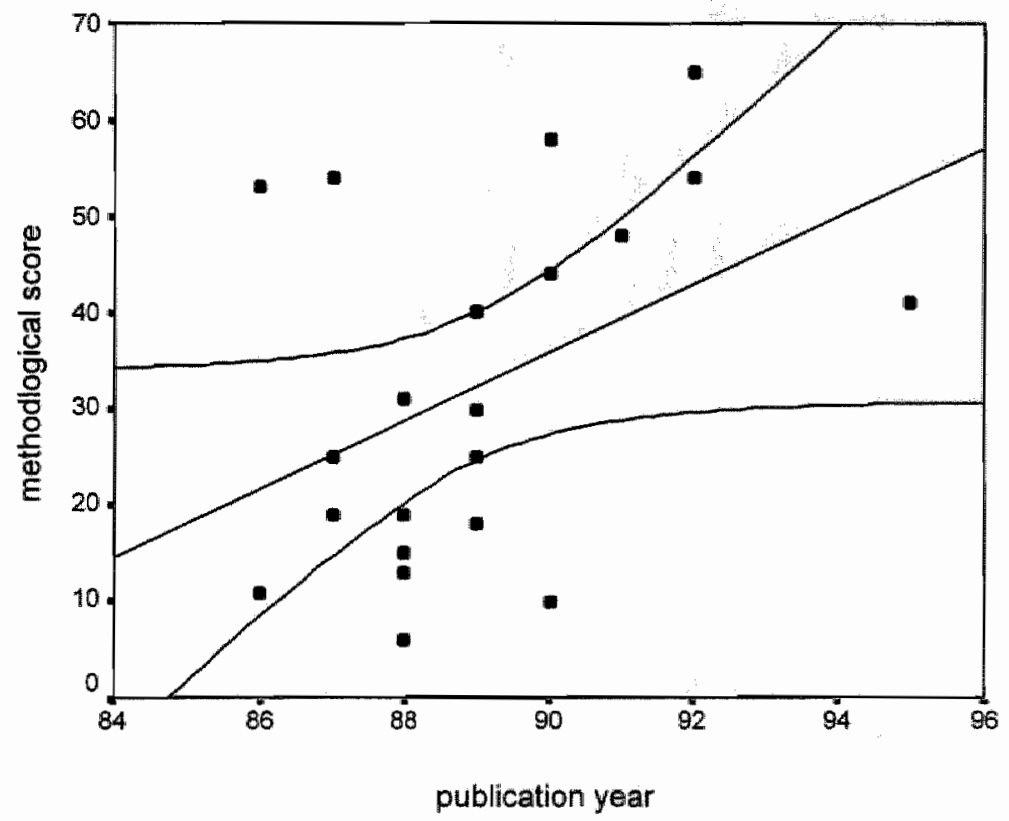

It is also noteworthy that studies with a negative outcome (according to the authors) have on average a significant better methodological score $(\mathrm{p}=0.01)$. The average methodological score for positive studies is $25(\mathrm{sd}=13)$, and for negative studies 42 ( $s d=14)$. This phenomenon could be hinting at publication bias, showing that positive studies with low methodological quality get published more easily.

The methodological score of the studies is based on the items that are reported and well performed. Figure 2 shows that the missing points are mainly due to lack of information and only to a minor extent to bias. 
Figure 2: Informativeness, non-informativeness and bias per study

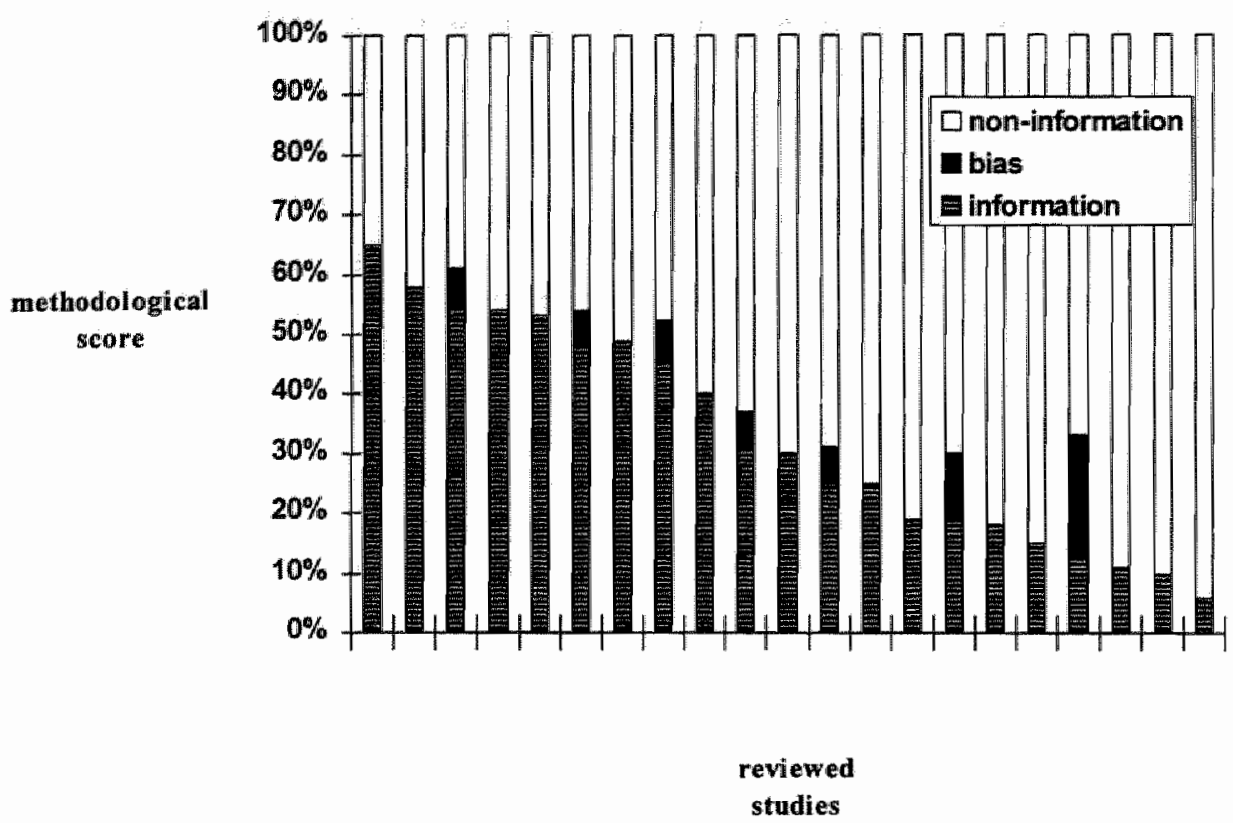

\section{Discission}

The value of a literature review depends on the success in obtaining the results of all trials (RCTs) which have been conducted on the issue of interest. It is possible that relevant studies reported in fora not accessible to us or in languages incomprehensible to us were omitted from this review. There are also indications that, especially, small clinical trials with negative results are not as easily published as small positive trials." Thus, publication bias could form a threat to the validity of the results presented here.

There is a considerable number of randomised clinical trials that study the effects of LT. However, many of the reviewed studies showed serious methodological flaws, and much information was lacking in the publications. When assessing methodological quality the primary goal is to achieve an estimate of both the effects and the chance of bias in the results of the studies performed ${ }^{47,43}$ One method of assessing quality is by using a criteria list which tries to measure internal validity, precision of the study and relevance of the choices with respect to population, interventions and measures of effect. Assigning weights to these criteria anticipates the argument that some errors in trial design are more crucial than others. Although controversial, weighting does give some insight into the quality of the studies performed and provides an overview of the credibility of the results. It also enables the reviewed studies to be ranked to some extent, 
according to their methodological quality. The fact that systematic reviews use reported materiall to judge the quality of the trials under consideration is a consequence of this type of research, but is also cause for concern. As seen in this review, the methodological score is more influenced by non-informativeness than by methodological flaws (see Figure 2). This is a pity, since non-informativeness could have been easily avoided by authors of studies or journal editors.

Of the 21 trials in our review 7 reported results that were not in concordance with a correct data-analysis procedure. When we corrected their positive outcomes by appropriate analysis, that is, analysis between groups instead of within groups, no effects of LT were found.

A study of the dosage in these trials did not reveal firm relationships between the dosage and the outcome of the study. In cases where no dosages were provided, but enough parameters were at hand to calculate the dose at skin level, this was done. Where necessary, specifications from the laser industry were obtained to be able to calculate the applied dosages as accurate as possible. The column "interventions" in Table 3 specifies which doses were calculated.

It should be noted that the actual laser dose is often lower than the one mentioned by the authors or the laser industry. We can think of five possible reasons for this. First, lasers used for medical purposes are allowed to deviate about $3 \%$ in output, thus delivering lower or higher output. Second, $904 \mathrm{~nm}$ lasers are notorious for cooling problems, since the output depends strongly on the rise in temperature of the laser resonator. The higher the temperature the lower the output. $904 \mathrm{~nm}$ lasers loose on average about $20 \%$ of their output in the first half hour. ${ }^{49} \mathrm{~A}$ third factor which influences output negatively is the optical system of the laser apparatus. Mirrors, fibre-optics and lenses all take away about $25 \%$ of the dose each. For instance a three mirror system, often used in laser devices capable of scanning an area, lose $75 \%$ in output due to these mirrors. Fourth, divergence of the laser bundle, which can amount to up to $35^{\circ}$ in $904 \mathrm{~nm}$ lasers, results in loss of energy..$^{50}$ Finally, reflection, refraction and absorption play an important role in diminishing output power, especially in laser scanning devices. Although these latter mechanisms are also claimed to be essential parts of the working mechanism, when output is lowered before reaching the target tissue, these phenomena work as barriers, preventing adequate dose delivery in the target tissue.

The 21 studied RCTs can be considered the best available evidence when studying the efficacy of $904 \mathrm{~nm}$ LT in musculoskeletal disorders. Because of their use of random allocation of the patients and the use of control treatments, their potential to supply valid answers is much larger than that of uncontrolled or non-randomised controlled studies. Nevertheless, the observed study quality ranged from very poor (6 points) to only reasonable ( 65 points). Many (avoidable) errors in design and data-analysis were noted. Therefore, we suggest that in the future more attention should be paid to larger sample sizes, improved prognostic conparability of the groups, and avoiding drop outs and cointerventions. Furthermore, mentioning sideeffects and the use of between group comparisons could help answer the question of whether $904 \mathrm{~nm} \mathrm{LT}$ has favourable effects in musculoskeletal disorders. Last but not least; better reporting of future studies is imperative. 
We did not pool the results of the trials because patient characteristics, illnesses studied and treatments given were not similar enough to allow for pooling, neither as a total nor in subgroups. In addition, the methodological quality of the studies was low. Furthermore, sixteen out of 21 studies did not present data that allowed pooling.

In conclusion, the results clearly show that the efficacy of LT in musculoskeletal disorders is questionable. In none of the studied diseases in which LT is supposed to be effective could firm evidence be provided that LT was superior to placebo, sham or other treatment modalities. Also, outcome measures such as general improvement or change in range of movement, failed to show advantageous effects of LT.

We conclude that there is little evidence that $904 \mathrm{~nm}$ LT in musculoskeletal disorders is effective. Larger trials with better methodological quality could provide more definite and convincing answers.

\section{RETERENCE}

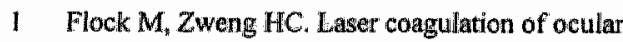
tissues. Archives of Ophtalmology 1964; 72: 604.

2 Goldman $L$. Wilson $R_{1}$ Hornby $P$ et al. Laser ladiation of malignancy in man. Cancer 1965; 1: 93-101.

3 Goldman IA. Investigative studies of laser technology in theumatology and immunology. Biomedical Laser Technology Clinical Applications New York: Springer Verllag, 1981.

4 Wei $X$. Laser treatment of common diseases in surgery and acupuncture in the people"s republic of China: preliminary report. Acupuncture Electro 1981; 6: 19-31.

5 Gallachi $\mathrm{G}_{n}$ Moller $\mathrm{W}$. Akupunktur und Laserstrahlenbehandlung beim Cervical- und Lumbalsyndrom. Z Phys Med 1981; 2: 95-102.

6 Lewith GT, Machin DA. A randomized trial to evaluate the effect of infra-red stimulation of local trigger points, versus placebo, on the pain caused by cervical osteoarthrosis. Acupuncture
Electro 1981; 6:277-84.

7 Diamanthopoulos C. Bicenergetics and tissue optics. In: GD Baxter. Therapeutic lasers: theory and practice. Churchill Livingstone, Edinburgh, 1994.

8 Belkin $M$, Schwartz M. New biological phenomena associated with laser radiation. Health Phys 1989; 4: 141-50.

9 Karu II. Molecular mechanism of the therapeutic effect of low intensity laser irradiation. Laser in Life Sciences 1988; 2: 53-74.

10 Basford JR. Low energy laser therapy: controversies and new research findings. Lasers in Surgery and Medicime 1989; 9: 1-5.

11 Keijzer M, Jacques SL, Prahl SA et al. Light distributions in antery tissue: Monte Carlo simulations for finite laser beams. Lasers in Surgery and Medicine $1989 ; 9: 148-54$

12 King PR. Low level laser therapy: a review. Physiotherapy Theory and Practice 1990; 6: 12738.

13 Kitchen SS, Partridge CJ. A review of low level laser therapy. Physiotherapy 1991; 77; 161-8.

14 Bouma MG, Buurman WA, Wildenberg FA.M van den. Low energy laser irradiation fails to modulate the inflammatory function of human monocytes and endothellial cells. Lasers in Surgery and Medicine 1996; 19: 207-15.

15 Pocock SJ. Clinical trials; a practical approach. John Wiley \& Sons, Chichester, 1991.

16 Meinert CL. Clinical trials; design, conduct and analysis. Oxford University Press, New York, 1986.

17 Riet G ter, Kleijnen $J$, Knipschild P. Acupuncture and chronic pain. A criteria based meta-analysis. J Clin Epid 1990; 43:1191-9.

18 Koes BW, Bouter LM Heijden GMM van der, Knipschild PG. Physiotherapy exercises and back pain. BMJ 1991; 302:1572-6.

19 Heijden GJMG van der, Beurskens AJHM, Koes BW, Assendelft WJ, Vet HCW de, Bouter LM. Traction for back and neck pain: a blinded review. Physical Therapy 1995; 75: 93-104.

20 Assendelft WJJ, Koes BW, Knipschild $\mathrm{PG}_{3}$ Bouter LM. The relation between methodological quality and conclusions in reviews of spinal manipulation. JAMA 1995; 274: 1942-8.

21 Beard $M$. Third intemational physiotherapy congress, Hong Kong. Link Printing Pty. Ltd, Sydney, N.S.W. 1990.

22 Bihari I, Mester AR. The biostimulative effects of low level laser therapy of longstanding crural 
ulcers using belium neon taser, thelium meon plus infrared lasers, and noncoherent light: preliminary report of a randomized double blind comparative study. Laser Therapy 1989; 1:75-8.

23 Ceccherelli F, Altafini L, Lo Castro G, A wila A, Ambrosio F, Giron GP. Diode laser in cervical myofascial pain: a double blind study versus placebo. Clin I Pain 1.989; 5: 301-4.

24 Dolan M, Spiker T, Valkenburg P, Sterenborg HJCM. Infra-rood softlaser behandeling van decubitus. Versus; Tijdschrift voor Fysiotherapie 1989; 7: 124-40.

25 England S, Farrell AJ, Coppock JS, Struthers G, Bacon PA. Low power laser therapy of shoulder tendonitis. Scand J Rheumatol 1989; 18; 427-31.

26 Flöter Th, Rehfisch HP. Schmerzbehandlung mit laser. Eine doppelblind-studie. Top Medizin $1990 ; 4: 53-57$.

27 Gobelet C, Meier IL, Volken H. Mid ou mythe laser et pathologie abarticulaire. In: Simon $\mathbb{L}$. Actualités reeducation fonctionelle readaptation. Paris: Masson, 1986 (Ile serie).

28 Hansen HJ, Thoroe U. Low power laser biostimulation of chronic oro-facial pain. A double-blind placebo controlled cross- over study in 40 patients. Pain 1990; 43: 169-79

29 Jensen $\mathrm{H}$, Harreby $\mathrm{M}$, Kjer J. Is infrared laser effective in painful arthrosis of the knee? Infrarod laser - effekt ved smertende knaeartose?\} Ugeskr Laeger 1987; 149: 3104-6.

30 Klein $R G$, Eek $B C$. Low energy laser treatment and exercise for chronic low back pain: double blind controlled trial. Arch Phys Med Rehab $1990 ; 71: 34-7$.

31 Longo $L$, Tamburini A, Monti A, Cattaneo L, Sesti AG. Treatment with $904 \mathrm{~nm}$ and $10600 \mathrm{~nm}$ laser of acute lumbago: double blind control. Laser, Clinicall research, 1988; 16-20.

32 Lucas, C, Moll WAW, Coenen CHM Low level laser therapy bij decubitus stadium III. Een dubbelblind, placebo gecontroleerd effectonderzoek (Low level laser therapy in pressure ulcersj) Afdeling Contractactiviteiten, Faculteit Gezondheidszorg, Hogeschool van Amsterdam; 1-53.

33 Lundeberg T, Haker E, Thomas M. Effect of laser versus placebo in tennis elbow. Scand J Rehabil Med 1987; 19: 135-8.

34 Meier $\mathrm{L}$, Kerkour $\mathrm{K}$. Traitement laser de la tendinite. Med Hyg 1988; 46: 907-11.

35 Nivbrant B, Friberg S. Laser tycks ha effekt pa knäledsartros men vetenskapligt bevis saknas.
Lakartidningen 1992; 89: 859-61.

36 Olavi A, Pekka R Kolari PJ Effect of the infrared laser therapy at treated and non-treated trigger points. Int I Acupuneture \& Electro- Therapeatics Res. 1989; 14:9-14.

37 Rogvi-Hansen $B$, Ellitsgaard $N$, Funch $M_{*}$ Dall-Jensen $M$, Prieske J. Low level laser treatment of chondromalacia patellae. International Orthopaedics 1991: 15: 359-61.

38 Seichert $N$, Schöps $P$, Siebert $W$, Schnizer $W$, Liebmeister R. Wirkung einer Infrarot-Laser-Therapie bei weichteilinheumatischen Beschwerden im Doppelblindversuch. Therapiewoche 1987; 37: 1375-9.

39 Siebert $W$, Seichert $N$, Siebert $B$, Wirth JC. What is the efficacy of 'soft" and "mid" lasers in therapy of tendinopathies? Arch Orthop Traum Surg 1987; 106: 358-63.

40 Vasseljen $O$, Hoeg N, Kjeldstad B, Johnsson A, Larsen $\mathrm{S}$. Law level laser wersus placebo in the treatment of tennis elbow. Scand J Rehab Med $1992 ; 24: 37-42$.

41 Vasseljen O. Low-level laser versus traditional physiotherapy in the treatment of tennis ellbow. Physiotherapy 1992; 78: 329-43.

42 Seichert N, Siebert, B, Schöps P. Die Soft und Mid Lasertherapie in der Physikalischen Medizin. Eine kritische Discussion. Z. Phys Med Baln Med Klim 1986; 15 : 400-4.

43. Gudmundsen J, Vikne I. Laserbehandling av epicondylitis humeri og rotatorcuffsyndrom. Nor Tidskr Idrettsmed, 1987; 2; 6-15.

44 Flöter $T$. Laser in the management of chronic pain. Scand J Acupuncture Electrotherapy 1987 ; 2: $18-21$.

45 Greathouse DG, Currier DP, Gilmore RL. Effects of clinical infrared lesser on superficial radial nerve conduction. Physical Therapy 1985; 65: 1184-7.

46 Dickersin $\mathbb{K}$, Chan $\mathrm{S}$, Chalmers TC, Sacks HS, Smith $\mathrm{fr} \mathrm{H}$. Publication bias and clinical trials. Contr Clin Trials 1987; 8: 343-53.

47 Lipsey $\mathrm{MW}$. Identifying potentially interesting variables and analysis opportunities. In: The handbook of research synthesis; eds. Cooper $\mathrm{H}$ \& Hedges LV. Russell Sage Foundation, New York, 1994.

48 Bie RA de. Methodology of systematic reviews: an introduction. Phys Ther Rev 1996; 1:47-51.

49 Dolan $M$, Spiker $T$, Valkenburg $P$. Laseronderzoek. Deel 1: een experimenteel placebo onderzoek naar de invloed van een 
infirirooud laserbehandeling op de wondgenexing bij decubitus. Dern Haag; Haagse Hogeschool, 1988.

50 Medisch Techniologische Dienst TNO. MTDmarktowerzicht Laserapparatur, fysiotheraplie. Leiden, MIDTNO, 1989.

\section{theteron}

\section{Each criterion is applied independent of the other criteria.}

Al If the target population (with certain disease or complaints) is defined by means of criteria for selection of patients (in- and exclusion criteria) 2 points

A2 if a homogenous study population is selected by means of restriction (to patients with or without certain characteristics or) 2 points

B1 if the allocation procedure used is randomised, if the allocation of the selected patients to the treatment groups does not lead to bias 10 points

B2 if the allocation procedure has been blinded 10 points

C if the study groups are comparable for the relevant prognostic variables 6 points

D1 if the smallest group immediately after randomisation is bigger than 25 patients 3 points

D2 if the smallest group immediately after randomisation is bigger than 50 patients

\section{3 points}

D3 if the smallest group immediately after randomisation is bigger than 75 patients

\section{3 points}

E1 if there are no drop outs 7 points, or

E2 if the number of patients that withdrew (drop outs) during treatment period after randomisation is given for each study group separately 2 points

E3 if reason for withdrawal of patients (drop outs) during treatment period after randomisation is given for each study group separately 2 points

E4 drop outs not leading to bias (less than $5 \%$ drop outs) 3 points

F Lass to follow-up: all randomised patients minus the number of patients at the main moment of follow-up measurement for the main outcome measure (if not stated then judgement according to the opinion of the reviewers), divided by all randomised patients, times $100 \%$

F1 if loss to follow-up is less than $20 \%$ in each group 1 point

F2 if loss to follow-up is less than $1.0 \%$ in each group 1 point

F3 if loss to follow-up does not lead to bias (according to reviewer) 1 point

G1 type of the intervention, if control group: is it a placebo control group? 2 points

$\mathrm{G} 2$ intensity/solution of the intervention 2 points

G3 duration/site of each treatment session 2 points

G4 frequency of treatment sessions 2 points

G5 total number of treatment sessions

\section{2 points}

G6 compliance described 2 points

$\mathrm{H}$ if all co-interventions are avoided in the design of the study (until the most important moment of effect measurement) 2 points or

if data about co-interventions are presented and comparable between the groups (until the most important moment of effect measurement) 2 points

II if patients were blinded (unaware of the treatment given), or when patients were not familiar with the experimental intervention (fully naive) 3 points

12 when blinding is evaluated and successful (in more than $90 \%$ of the patients in every study group) 3 points

$\mathrm{J} 1$ if the therapist who performs the 
treatment is blinded (unaware of the treatment given) 3 points

$\mathrm{J} 2$ if blinding of the therapist is evaluated and successful (in more than $90 \%$ of the patients in every study group) 3 points

$\mathrm{K} 1$ if the observer who conducts outcome measurements is blinded (unaware of the treatment given) 3 points

K2 if blinding of the observer is evaluated and successful (in more than $90 \%$ of the patients in every study group) 3 points

$L$ if the results are reported explicitly for the following outcome measures maximum 5 points

LI pain

L2 global measure of improvement for the presented symptoms

L3 other outcome measures used (if relevant)

L4 other outcome measures used (if relevant)

L5 other outcome measures used (if relevant)
M1 if the timing of measurement is comparable 2 points

$\mathrm{M} 2$ if the moment of effect measurement is immediately after the last treatment 1 point

M3 if the moment of effect measurement is after 3 months or longer (after randomisation), or at an adequate time (according to reviewer) 2 points

$\mathrm{N}$ if side effects were reported for each group separately 2 points

$O$ if frequencies or mean \& standard deviation or median \& quartiles are presented for most important outcome measure on the most important moment of effect measurement 1 point

$P$ intention-to-treat-analysis as well as an alternative analysis (worst-case-analysis which accounts for drop outs and missing values) is presented for most important outcome measure on the most important moment of effect measurement 3 points

Q If adequate corrections for base-line differences or drop-outs on most important outcome measures are presented 3 points 


\author{
Robert A de Bie, MA, PT \\ Henrica CW de Vet, $\mathrm{PhD}^{\mathrm{I}}$ \\ Frans A.JM van den Wildenberg, $\mathrm{MD}, \mathrm{PhD}^{2}$ \\ Ton Lenssen, $\mathrm{PT}^{3}$ \\ Paul G Knipschild, MD, PhD \\ 'Department of Epidemiology, Maastricht University \\ "Departnent of General Surgery, University Hospital of Maastricht \\ ${ }^{3}$ Department of Physiotherapy, University Hospital of Maastricht
}

We developed a new diagnostic tool for predicting the severity of ankle sprains just after injury. Since hard data obtained by diagnostic imaging techniques are still imperfect, we decided to use data from history taking and signs and symptoms that are part of the intake routine. During a three month period data were collected on thirty-five patients with lateral ankle sprains who visited the first aid department of the University Hospital of Maastricht. Assessments took place at intake and at two and four weeks after injury. Assessors were the first aid physician, a physiotherapist and the patient. Dependent variables were healed ankle in two and four weeks. Predicting variables were the data obtained at intake by the physician, the physiotherapist and the patient. The ability to predict outcome after two and four weeks was determined in a bivariate analysis, followed by logistic modelling.

Accurate prediction of recovery time at intake appeared to be possible. Best two weeks predictor was the modified function score, an accuracy of $97 \%$ was achieved. Four weeks prediction was most accurate when function score was used together with the report mark from the doctor and the palpation score (accuracy of $81 \%$ ).

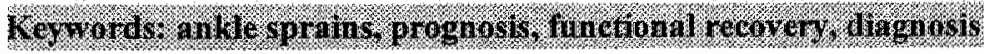




\section{Treroniction}

In the Netherlands one in four sports injuries concerns the ankle. ${ }^{*}$ In hospitals four out of 1000 Dutch people ane treated for ankle sprains every year. The costs involved are high. Moreover, expenses on sick leave and (semi)permanent invalidity are even higher, since about a quarter of all injured people are absent from school or work for more than seven days. Data from studies in other countries confirm these findings. $9,1,16,20$

Ankle sprains are quite common (in fact they are the most frequent form of ankle injury), yet there seems to be only consensus about initial treatment. Rest, Ice, Compression and Elevation (RICE) are considered to be appropriate and effective. ${ }^{5,22}$ Rucinsky et al. ${ }^{21}$ on the other hand question the effectivity of compression. Also there has been a shift from a static (plaster of Paris) to a more dynamic treatment approach (taping or brace) over the last decade., ${ }^{712}$ Plaster of Paris evidently shows worse results than operation or taping, and the latter shows quicker functional recovery and re-uptake of work. ${ }^{1,7,12}$ Efficacy of additional treatments like functional exercise therapy, laser therapy, ultrasound therapy or electro therapy show conflicting results, $1,3,7,13,14,23$ Reasons for non-tuniformity of treatment are, among other things, the difference in tradition and severity of trauma. Being able to separate mild from severe cases has a major advantage; mild cases could receive less or modified treatment (and save costs), while more severe cases can be treated more suitably. Adequate treatment procedures could be initiated from the moment of diagnosis, if prediction of clinical outcome is possible. Probably early initiation of adequate treatment also reduces the reported 10-20 percent of chronic lateral ankle instabilities after treatment $^{6,11}$ to a major extent.

Lack of proper diagnostic criteria hampers discrimination between mild and severe sprain injuries. Yet, studies report a whole range of diagnostic tesis for evaluating lateral ankle sprain injuries. $1,3,7,83,18,23$ Severe injuries such as fractures and avulsion fractures can be adequately detected by $X$-ray examination. Van Moppes and Van den Hoogenband ${ }^{1:}$ found that the severity of the injury cannot be determined by means of stability and stress photography. Jongen" states that "the very limited value of X-ray photography in the diagnosis of ankle sprains, by means of stress tests or arthrography, is due to low reproducibility, low correllation with objective findings and complaints and investigator dependency." Other diagnostic imaging techniques such as CT-scan or ultrasound are difficult to interpret, so the extent of the damage is hard to determine. MRI (Magnetic Resonance Imaging) might be an adequate solution to determine the extent of tissue damage and indeed it might be used as a gold standard in studies to assess the validity of less expensive diagnostic instruments. However, costs of this technique are extremely high and go beyond everyday routine. In MRI diagnostics one assumes that tissue damage reflects the severity of the injury. It is questionable whether this is correct. It seems more appropriate to define the severity of injury in terms of prognosis. Injuries that heal in a short span of time are very likely to be mild injuries, where longterm recovery of ankle sprains suggests the presence of a severe injury. Of course, age and workload might prove factors modifying recovery rate.

We performed a study to elucidate diagnostic criteria for severity of ankle sprains. We decided to use data from history taking and signs and symptoms that are already part of the intake routine. Our primary study objective 
was to examine whether it is possible to distinguish between mild and severe cases at intake (just after the injury has occurred), solely on the basis of these data. Outcome was defined on the basis of clinical course and functional recovery.

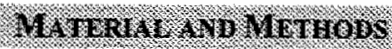

During a three-month period (15 September 15 December, 1992) data were collected from 35 consecutive patients with a lateral ankle sprain injury visiting the first aid department of the University Hospital of Maastricht. This is the only hospital in the area. The catchment area is rather large and about $50 \%$ of the population are known to report with an ankle sprain injury due to sports activities. After the patients had given informed consent, assessments of their ankles were made on three moments: at intake, at two weeks and at four weeks after injury. A routine follow-up was performed at six weeks. The three assessors, the first aid physician, a physiotherapist and the patient, were blinded for each other's data.

A standardized intake by the first-aid physician and an X-ray examination were carried out. Patients with fractures and/or severe injuries demanding operative interventions, as well as patients with open wounds were excluded from participation in this trial.

Hour and date of injury, time and hour of visit to the first aid department and activity during which the injury had occurred were recorded. Swelling, spontaneous pain, kissing pain (pain on the medial malleolus because the medial malleolus collides with the talus) and occurrence of previous ankle sprains in the last year, as well as ankle stability and function were judged.
The doctor asked which first aid measures had been taken immediately after injury and recorded data on sports participation and sports level. Most of these questions are part of the normal hospital routine, but were standardised for the purpose of the investigation. In addition, the doctor had to estimate the severity of the injury by means of a report mark at intake. The report mark ranged from 0 to 10 points, where 10 points represented the most severe injury. The doctor also predicted the chance of recovery at two and four weeks after initial injury. Finally the number of days after which the patient could go back to work or school and participate in sports activities had to be estimated. All these assessments were made at intake.

At intake, and at two and four weeks the physiotherapist carried out a palpation and stress test. This test consisted of detecting the most painful area by means of a pressure gauge and manual stress of the three lateral ligaments.

The severity of the ankle injury was assessed by means of a function score. The function score was derived from the Lysholm score ${ }^{15}$ and adapted for ankle sprain injuries. Originally, the Lysholm score was developed for patients with knee problems. It measured the patients' capability of performing activities of daily life when assessing function in relation to level of complaints.

The function score consists of five categories (table 1) on which a number of points could be achieved. To reach 75 points or more, the patient had to score rather high in every category. This represents being able to maintain a normal gait pattern under almost all circumstances. 
Table 1: Function score for assessment of lateral ankle sprains

\begin{tabular}{|c|c|c|}
\hline 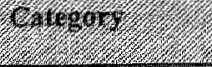 & $\operatorname{ten} 2$ & sore \\
\hline \multirow[t]{8}{*}{ Pain } & none & 35 \\
\hline & during sports & 30 \\
\hline & during running on non-level surface & 25 \\
\hline & during runining on level surface & 20 \\
\hline & during walking on non-level surface & 15 \\
\hline & during walking on level surface & 10 \\
\hline & whille carrying load & 5 \\
\hline & constant pain & 0 \\
\hline \multirow[t]{6}{*}{ Instability } & none & 25 \\
\hline & sometimes during sports (less than once a day) & 20 \\
\hline & frequently during sports (daily) & 15 \\
\hline & sometimes during $\mathrm{ADL}^{*}$ (less than once a day) & 10 \\
\hline & frequently during $\mathrm{ADL}^{*}$ (daily) & 5 \\
\hline & every step & 0 \\
\hline \multirow[t]{5}{*}{ Weight bearing } & jumping & 20 \\
\hline & standing on toes of injured leg & 1.5 \\
\hline & standing on injured leg & 10 \\
\hline & standing on two legs & 5 \\
\hline & none & 0 \\
\hline \multirow[t]{4}{*}{ Swelling } & none & 10 \\
\hline & light & 6 \\
\hline & mild & 3 \\
\hline & severe & 0 \\
\hline \multirow[t]{4}{*}{ Cait pattern } & running & 10 \\
\hline & normal gait & 6 \\
\hline & mild limp & 3 \\
\hline & severe limp & 0 \\
\hline
\end{tabular}

"ADL: activities of daily liwing

The patient filled out questionnaires at intake and at two and four weeks. Information was asked about severity of pain, ability to work (or go to school), ability to participate in sports activities and ADL handicap. At two and four weeks the patient was asked about the number of days he or she had already returned to work and/or performed sports activities. During the assessment period all patients received the same treatment regimen. Initial treatment consisted of a pressure bandage until swelling had been reduced or until the ankle could be dorsiflected to an angle of 90 degrees. Then a taping procedure according to the Coumans protocol $^{18}$ was applied. The taping was renewed every fortnight. After six weeks 27 of the 35 patients were cured. Five patients were still having difficulty in performing $\mathrm{ADL}$ activities and received further treatment (physiotherapy), while their ankle was supported 
by a brace when necessary. Three patients were lost to follow up.

\section{Sthisticht Arintris}

The obtained data were first analysed bivariately and subsequently multivariately by means of logistic modelling ${ }^{2,19}$ in order to be able to predict outcome. Dependent dichotomous variables were healed in two and four weeks respectively. A patient was considered healed when he or she obtained more than 75 points out of 100 on a function score, and received a score of less than two out of twelve points on the palpation and/or stresstest, measured at two and four weeks respectively. Predictor variables were all variables obtained at intake.

\section{Ressuts}

From all thirty-five persons a complete intake form was obtained. Data on two and four weeks assessment was obtained in thirty-three and thirty-one of the initially enrolled patients respectively. The missing cases had no complete follow up, were missed by one of the assessors or had incomplete forms. Mean age of the patients was 28 years (sd 10; range 1359). There were thirteen females and twentytwo males. Almost all patients had pain and swelling at intake; fourteen out of thirty-five patients had a swelling at intake that developed slowly, rather in days than hours. In about $50 \%$ of the cases the 'kissing' phenomena had occurred, and $43 \%$ could bear weight on the injured foot (and thus supporting full body weight).
Injuries had occurred during work (17\%), during sports activities ( $57 \%$ ) and at home or elsewhere $(26 \%)$. Half of the sports injuries were due to playing soccer.

of the cases $71 \%$ had some first aid measure taken; $66 \%$ had been treated with ice or water for cooling, $23 \%$ had been given a wrapping and about $20 \%$ had elevated the injured foot. Several variables were assessed by both the first aid physician and the physical therapist. These data were used as a cross-check instrument and were very similar. We chose to use the data obtained by the physician because he or she is the person who has to make a proper diagnosis in daily practice.

Table 2 presents two and four weeks outcome related to data from history taking and signs and symptoms. The table should be interpreted as follows: of the injured patients who where still injured after two weeks $93 \%$ had spontaneous pain at intake compared to $75 \%$ of the cured patients.

It appeared that the function score was an excellent predictor for healing within two weeks. This is no surprise since the function score is an index that combines the items pain, instability, weight bearing, swelling and gait pattern. Individually these items also relate rather well to outcome, especially weight bearing. The doctors' prediction of cure in four weeks is rather poor. Table 3 shows a sensitivity of $97 \%$ and a specificity of $100 \%$ for the function score as a diagnostic test, when discriminating between light and severe ankle sprain. Light and severe sprains are defined as being cured within two weeks or not. 
Table 2: Prediction on two and four weeks outcome on data from history taking and signs and symptoms used by the first aid doctor

\begin{tabular}{|c|c|c|c|c|}
\hline 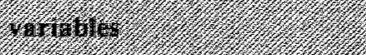 & 1005 & iforitive & Conro & aiternic \\
\hline & 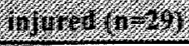 & $160+10=4$ & 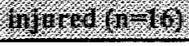 & 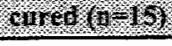 \\
\hline gpontaneous pain & $93 \%$ & $75 \%$ & $93 \%$ & $80 \%$ \\
\hline Híssing pin & $55 \%$ & $25 \%$ & $50 \%$ & $47 \%$ \\
\hline Instability' severe & $15 \%$ & $0 \%$ & $21 \%$ & $7 \%$ \\
\hline - moderate & $54 \%$ & $50 \%$ & $71 \%$ & $43 \%$ \\
\hline not 2 & $31 \%$ & $50 \%$ & $7 \%$ & $50 \%$ \\
\hline weight bearing impossible & $66 \%$ & $0 \%$ & $56 \%$ & $47 \%$ \\
\hline swelling - & $96 \%$ & $75 \%$ & $100 \%$ & $93 \%$ \\
\hline rather poor gail & $100 \%$ & $75 \%$ & $100 \%$ & $93 \%$ \\
\hline finetion segre $>35$ & $97 \%$ & $0 \%$ & $94 \%$ & $73 \%$ \\
\hline rather poor ankle function & $62 \%$ & $50 \%$ & $71 \%$ & $50 \%$ \\
\hline 82 pantul points & $66 \%$ & $25 \%$ & $64 \%$ & $47 \%$ \\
\hline >21 1gaments painfill on stress & $62 \%$ & $0 \%$ & $62 \%$ & $47 \%$ \\
\hline recidive & $27 \%$ & $25 \%$ & $13 \%$ & $47 \%$ \\
\hline 4 severity (repon mark $(5)$ & $76 \%$ & $25 \%$ & $88 \%$ & $60 \%$ \\
\hline lnot cured within 2 weeks? & $88 \%$ & $50 \%$ & $93 \%$ & $79 \%$ \\
\hline not cured witlin 4 weeks & $8 \%$ & $25 \%$ & $0 \%$ & $14 \%$ \\
\hline not at work within 7 days & $15 \%$ & $0 \%$ & $29 \%$ & $0 \%$ \\
\hline not sports within 2 weeks & $55 \%$ & $33 \%$ & $60 \%$ & $33 \%$ \\
\hline
\end{tabular}

No data available of 2 patients at two weeks, and 4 patients at four weeks

* Instability was defined by the doctor on duty on a 3 -point scale

Table 3: Prediction of two weeks outcome by function score

\begin{tabular}{|c|c|c|c|c|}
\hline & & \multirow{2}{*}{\multicolumn{2}{|c|}{ 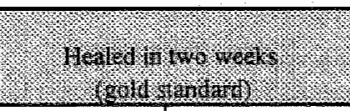 }} & \\
\hline & & & & \\
\hline & & injured & cured & \\
\hline \multirow{2}{*}{ (1) } & $\begin{array}{c}\text { injured } \\
(\leq 35 \text { points }) \\
\end{array}$ & 28 & 0 & $\begin{array}{l}\text { Pred val } \\
+100 \% \\
\end{array}$ \\
\hline & $\begin{array}{c}\text { cured } \\
(>35 \text { points })\end{array}$ & l & 4 & $\begin{array}{c}\text { Pred val } \\
-80 \%\end{array}$ \\
\hline & & Sens $97 \%$ & Spec 100\% & \\
\hline
\end{tabular}

Healling within four weeks was best predicted by the report mark for severity that the physician gave at intake together with the function score and pallpation score. Yet, in six out of 31 patients the wrong prediction is made. Table 4 showrs the results of prediction by these variables at the moment of intake, when compared with healing in four weeks. Sensitivity was $81 \%$ and specificity was $80 \%$. 
Table 4: Prediction of four weeks outcome by report mark, function score and palpation score

\begin{tabular}{|c|c|c|c|c|}
\hline & & \multicolumn{2}{|c|}{ 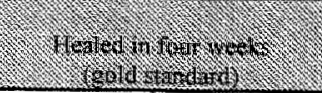 } & \\
\hline & & injured & cured & \\
\hline \multirow{2}{*}{ 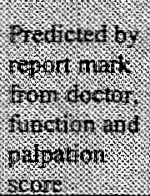 } & injured & 13 & 3 & $\begin{array}{l}\text { Pred val } \\
+81 \%\end{array}$ \\
\hline & cured & 3 & 12 & $\begin{array}{l}\text { Pred val } \\
-80 \%\end{array}$ \\
\hline & & Sens $81 \%$ & Spec $80 \%$ & \\
\hline
\end{tabular}

The probability function defining the odds to be cured within four weeks conditional on the intake criteria report mark, function score and palpation score reads as follows:

$$
\text { Prob }=\frac{1}{1+e^{(-0.81+\text { report mark } \times 0.54-\text { function score } \times 0.07+\text { palpation score } \times 0.34)}}
$$

We also developed an even more complex model, where interaction terms of the variables were considered. In that case sensitivity was $88 \%$ and specificity was $87 \%$. Yet, adequate use of such a model might prove difficult in daily practice.

\section{Discussion}

Exploratory studies, such as this one, have their limitations. Although they can provide new insights in underinvestigated territories, the results from such studies should be confirmed to be good predictors in subsequent studies. It should be kept in mind that the designed test was developed on the basis of a small study population.

In this study we tried to solve a diagnostic problem by studying prognosis. We chose prognosis in terms of recovery time as a measure of severity. Taking prognosis as a gold standard for diagnosis requires proper discrimination between diagnostic indicators, prognostic determinants and adequate outcome parameters. Some variables in this trial are hardly sensitive to change at all (e.g., age) but are good predictors for prognosis. Other variables (e.g., pain) measure change very satisfactorily, but are of no value when predicting variables at the onset of the complaint. Every sprained ankle is painful, thus pain cannot discriminate between light and severe injuries (table 2).

It seems strange that the doctors' prediction of cure in four weeks performs rather poorly, while their report marks for severity performs rather well. Apparently doctors use different data for diagnosis and prognosis. It seems that in order to predict prognosis they use variables with poor predictive value.

It can be argued whether our operationalisation of being healed within two and four weeks is valid. Choosing cut-off points to declare a patient cured or not after two weeks 
is very subjective. The cut-off point for being healed was defined as obtaining more than 75 points on a function score and scoring less than two out of 12 points on the palpation and/or stress test. This definition is arbitrary. As suggested in the prologue, accurate prediction on the basis of walking ability just after injury seems feasible. For being able to walk, minimal 35 points need to be obtained. If we look at the function score, combinations of the following items fulfill these conditions; the ability to walk on level surface (10 points), a rather low level of instability (10 points), being able to stand on one leg (10 points), allowing for gait ( 3 points) and another 3 points for not too much swelling.

The fact that it was possible to predict outcome in acute lateral ankle ligament injury is promising. Not only is the accuracy of the diagnostic instrument used here high, it also totally depends on non-imaging techniques. For two weeks prediction a standardised scale suffices, where for four weeks prediction, additional information from the doctor and the palpation score is necessary.

It is shown that although long-term prediction may require more elaborate models, accuracy of the prediction can be fairly high. As a tool for everyday practice we think that a rule of thumb might be feasible. When a given patient (i) scores more than 35 points on the function score and (ii) is assessed by the doctor as having a report mark of more than five out of ten (see table 2), the patient has a high probability of being cured within two weeks.

\section{Coxcusior}

Through the use of history taking and signs and symptoms that are already part of the intake routine it seems possible to predict the severity of the injury fairly accurately. Prediction of two weeks recovery can be done based on one variable: function score, whereas four weeks prediction appears to involve more variables: function, opinion of the doctor and palpation score. Often used variables such as pain and swelling appear to be poor predictors on their own. Further investigation is necessary to confirm these findings.

\section{RERERTERS}

1. Airaksinen $\mathrm{O}$, Kolari $\mathrm{PJ}_{*}$ Miettinen $\mathrm{H}$. Elastic bandages and intermittent pneumatic compression for treatment of acute ankle sprains. Archives of Physical Medicine and Rehabilitation 1990; 71: 380-3.

2. Altman DG. Practical statistics for medical research. Chapman \& Hall, London, 1991.

3. Bie RA de, Steenbruggen RA, Bouter LM. Effekt van lasertherapie op inversie-traumata van de enkel. (Efficacy of laser therapy in acute lateral ankle sprains) Nederlands Tijdschrift voor Fysiotherapie 1988; 95: 108-12.

4. Bol E, Schmickli SL, Backx FJG, wan Mechelen W. Sportblessures onder de knie: programmering van toekomstig onderzoek. (Control over sports injuries: planming future research) NISGZ, March 1991.

5. Coté DJ, Prentice WE, Hooker DN, Shields EW. Comparison of three treatment procedures for minimalizing ankle sprain swelling. Physical Therapy $1998 ; 68(7): 1072-6$.

6. DeMaio $M$, Paine $R$, Drez $D$. Chronic lateral ankle instability - inversion sprains part $I$. Sports Medicine Rehabilitation Series. Orthopedics, 1992; $15(1): 87-96$.

7. Ent FWC van der. Letsels van het laterale enkelbandapparaat. (Lateral ankle joint ligament imjuries) Nederlands Tijdschrift voor Fysiotherapie 1991; 96: 121-3. 
8. Galen WCC van, Diederiks J. Sportblessures breed uitgemeten. (Sports inyiries in a wider perspective) De Vrieseborch, Haarlem 1990.

9. Greene TA., Wight CR. A comparative support evaluation of three ankle orthoses before, during and after exercise. JOSPT 1990; 11: 453-66.

10. Jongen SJM, Pot JH, Dunki Jacobs PB. De behaundeling van de verzwilkte enkel. (The treatment of the sprained ankle) Geneeskunde en Sport 1992; 25(3): 98-101.

11. Karlsson $\mathrm{J}$, Lansinger $\mathrm{O}$. Lateral instability of the ankle joint. Clinical Orthopaedics and Related Research 1992; 267: 253-61, 1992.

12. Kannus $P$, Rennstrờm $P$. Treatment for acute tears of the lateral ligaments of the ankle. J Bone Joint Surg Br 1991; 73A: 305-12.

13. Korkala O, Rusanen M, Jokipii P, Kytömaa J, Avikainen V. A prospective study of the treatment of severe tears of the lateral ligament of the ankle. International Orthopaedics 1987; 11: 13-7.

14. Lilius $\mathrm{HG}$, Valtonen $\mathbb{E}$, Pasila $M$, Visuri $\mathbb{T}$,

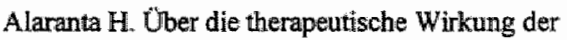
diadynamischen Ströme an Bandverletzungen des Fusses; kontrollierte Untersuchung an 248 Patienten. Zeitschrift Physiotherapie 1975; 27: 331-4.

15. Lysholm J, Gillquist $J$, et al. Evaluation of knee ligament surgery resuits with special emphasis on use of a scoring scale. American Joumal of Sports Medicine 1982; 10 (3):150-4.
16. Miller EA, Hergenroeder AC. Prophylactic ankle bracing. Sports Medicine $1990 ; 37(5)) 1175-85$.

17. Moller-Larssen $\mathrm{F}$, Wethehund JO, Jurik $\mathrm{AO}_{\mathrm{B}}$ de Carvallio A, Lucht $U$. Comparision of three different treatments for ruptured lateral ankle ligaments. Acta Orthopedica Scandinavia 1988; $59(5): 564-6$.

18. Moppes FI van, Hoogenband $C R$ van den. Diagnostic and therapeutic aspects of inversion trauma of the ankle joint. Dissertation, Maastricht, 1982.

19. Norusius MJ. SPSS for Windows Professional Statistics, release 6.1, Illinois, U.S.A., 1993.

20. Packer $\mathrm{GJ}$, Goring $\mathrm{CC}$, Gayner $\mathrm{AD}$, Crax ford $A D$. Audit of ankle injuries in an accident and emergency department. BMJ 1991; 302: 885-7.

21. Rucinski TJ, Hooker DN, Prentice WE, Shields EW, Cote-Murray DJ. The effects of intermittent compression on edema in post acute ankle sprains. JOSPT 1991; 14(2): 65-9.

22. Wilkerson GB, Horn Kingery HM. Treatment of the inversion ankle sprain: comparison of different modes of compression and cryotherapy. JOSPT 1993 17(5); 240-6.

23. Williamson JB, George TK, Simpson DC, Hannah B, Bradbury E. Ultrasound in the treatment of ankle sprains. Injury 1986; 17:176-8.

24. Zwipp $H$, Hoffman $R$, Thermarn $H$, Wipperman $\mathrm{BW}$. Rupture of the ankle ligaments. International Orthopaedics 1991; 15: 245-9. 
D EFTICACY OF IUASER THERAPY IN

ANKA I SPRAINS

\title{
DESTGN OF A RA NDOMISED CINICAL TRIAL
}

\author{
Robert A de Bie, MA, PT \\ Henrica CW de Vet, $\mathrm{PhD}^{\mathrm{i}}$ \\ Frans $\mathrm{AJM}$ van den Wildenberg, $\mathrm{MD}, \mathrm{PhD}^{2}$ \\ Anton Lenssen, $\mathrm{PT}^{3}$ \\ Lex M Bouter, $\mathrm{PhD}^{4}$ \\ Paul G Knipschild, $\mathrm{MD}, \mathrm{PhD}^{1}$ \\ 'Department of Epidemiology, Maastricht Uniwersity \\ ${ }^{2}$ Department of General Surgery, University Hospital of Maastricht \\ ${ }^{3}$ Department of Physiotherapy, University Hospital of Maastricht \\ ${ }^{4}$ EMGO-institute, Free University of Amsterdam
}

\section{Arsireter}

Studies on low intensity $904 \mathrm{~nm}$ laser therapy in the treatment of musculoskeletal disorders show conflicting results. Yet, on the basis of an earkly systematic review we concluded that $904 \mathrm{~nm}$ laser therapy for musculoskeletal disorders seems to be promising, when compared to placebo laser therapy. Quick pain relief and fast functional recovery are reported to be the most prominent claims of laser therapy.

This paper presents a rationale of choices regarding the patients and type of treatment when designing a randomised, double blind, clinical trial on $904 \mathrm{~nm}$ laser therapy, as well as safeguards concerning optimum dose, constancy of dose and double blinding the actual laser therapy.

Keywordis ReT, 904 nm laser, It teral ankle sprain 


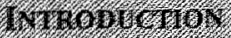

Since the early nineteen eighties the biological and medical effects of low level laser therapy (LLLT) have been studied. During this time, many articles have appeared in North American and European journals. Nevertheless, the subject remains controversial, with many medical scientists doubting the validity of the claims attributed to LLLT. $1, \bar{a}$

Two aspects have attributed to this controversy. Firstly, many of the reports on low level laser therapy show serious methodological flaws and, therefore, the validity of the reported effects is questionable.. ${ }^{3}$ Secondly, the lack of convincing elucidation of biological mechanisms explaining the clinical effects induced by LLLT, also hampers acceptance. Moreover, arguments and specu-lation about proper dosages and treatment indications arise from this lack of know-ledge. ${ }^{4}$

On the basis of a systematic review of 35 randomised clinical trials it was concluded that LLLT for musculoskeletal disorders seemed to be promising, when compared to placebo laser therapy. ${ }^{3}$ Randomised clinical trials in rheumatic diseases and post traumatic injuries showed quick pain relief and a quicker functional recovery; yet, in the treatment of soft tissue injuries conflicting results were reported. Owing to the poor methodological quality of the studies, conclusions about the effectivity of LLLT should be drawn with caution.

In this paper we present the proposed study design of our randomised clinical trial (RCT) on the efficacy of LLLT for the treatment of acute lateral ankle sprains. Several arguments can be given to publish a trial design before publishing the data generated from the actual trial. First, it prevents publication bias. It is known that only part of the studies which have been performed are actually published, and unpublished studies sometimes show different results from the published ones. ${ }^{5}$ Second, eritical assessment of the study method independent of study outcome is possible, thus allowing the reader to check for explicit choices regarding design, dosimetry and study population. Third, the publication of choices made in measures of effect and analysis strategies prohibits selective data reporting, and prevent data dredging or skewing.

This paper discusses choices regarding the selection of patients and the selection of the appropriate LLLT wavelength and dosage. In addition, the most important outcome measures and preferred data analysis strategies are presented.

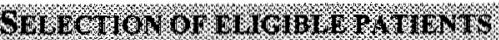

When selecting patients for an RCT on the efficacy of LLLT, four guiding principles apply. Firstly, the patients need to present with a lesion that appears frequently, for reasons of trial efficiency and relevancy. Secondly, to be effective, the lesion has to be located just under the skin surface and should allow a clear localisation of the region. The rays from a laser apparatus as used in physiotherapy only permit superficial and small area irradiation. Thirdly, the laser therapy is intended to serve as an additional therapy and, therefore, the basic treatment protocol should allow for standardisation to prevent differences in co-interventions among the contrasted groups in the trial. Fourthly, to test the claim that LLLT gives quick pain relief and fast functional recovery, a type of injury has to be chosen which presents initially with a fair amount of pain and loss of function.

A type of disorder that meets all these criteria 
is a lateral ankle sprain. Lateral ankle sprains occur frequently. In the Netherlands alone, 4 out of 1000 people are treated for ankle sprains every year. ${ }^{6}$ In our intended research location, the University Hospital of Maastricht, about 600 patients per year seek medical aid after a lateral ankle sprain. Ankle sprains are superficial injuries and can be localised easily. In addition, it seems possible to standardise the treatment regime. Lastly, ankle sprains typically present initially with quite a lot of pain and functional impairment.

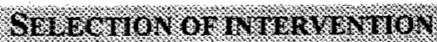

Although laser therapy has been investigated and used clinically for about twenty years, biological mechanisms and clinical effects are hardly understood. Until now it remains unclear which wavelength and what dosage, if any, should be used to obtain optimal results. ${ }^{4,7}$ Based on theoretical arguments and previous research we tried to determine the most optimal wavelength for treating soft tissue injuries. $^{8}$

Laser light with a wavelength between 790 and $950 \mathrm{~nm}$ penetrates the skin most easily. Comparison with wavelengths of 600 to 790 nm shows considerable differences in penetration depth. Wavelengths of 600 to 790 nm penetrate the tissue up to about $4 \mathrm{~nm}$, whereas wavellengths between 790 and 950 nm penetrate the tissue up to $5 \mathrm{~cm}$ or more: The highest intensities for the latter are reached just below the skin. Recent research shows that not only the depth which laser light reaches, but also the intensity of laser light at that particular depth determines whether laser therapy can be successful or not. A certain amount of incident photon energy (threshold dose) is needed to trigger biochemical reactions in the target tissue, in order to be effective. Results from randomised clinical trials about the efficacy of LLLT laser ${ }^{3}$ show that trials with positive findings report an average dose at skin level of $1.3 \mathrm{~J} / \mathrm{cm}^{2}$ (SD 1.31), ${ }^{10-18}$ whereas negative trials report an average dose of $0.49 \mathrm{~J} / \mathrm{cm}^{2}$ (SD 0.72$)^{19-27}$

The therapeutic dose of LLLT varies enormously. Reported doses at tissue level range from $0.0005 \mathrm{~J} / \mathrm{cm}^{227}$ to $3.97 \mathrm{~J} / \mathrm{cm}^{2}{ }^{1.5} \mathrm{No}$ adverse reactions from $904 \mathrm{~nm} \mathrm{LLLT}$ have been reported in the normal therapeutic range. Go et al., ${ }^{28}$ reported adverse skin reactions in doses above $450 \mathrm{~J} / \mathrm{cm}^{2}$. These doses lie far above the therapeutic maximum that is used in physiotherapy.

Figure 1 shows the dose, range and outcome of the reported trials. Positive trials appear to have used higher doses throughout the entire range than have the negative trials.

Figure 1. Trial outcome related to average dose and $95 \% \mathrm{Cl}$ 's

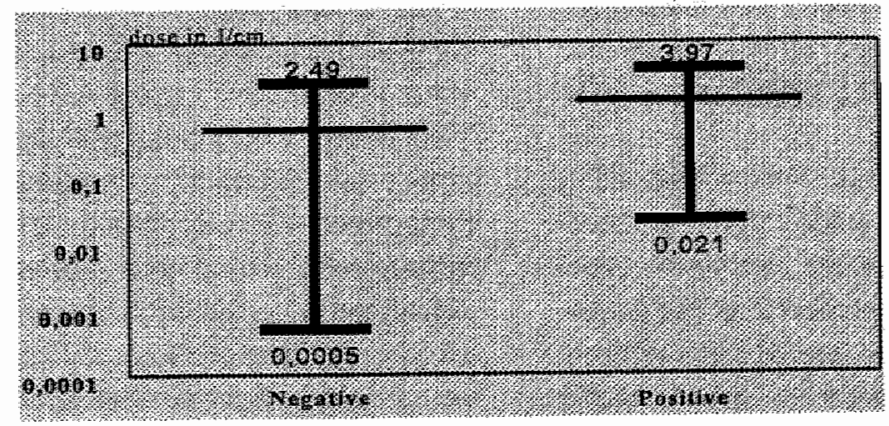


As discussed previously, not only the total dose but also the intensity seems relewant. One can imagine that reaching a threshold in a shorter time might be economical, yet too high an intensity might show adverse effects. No one knows yet whether there might not be a rebound effect when applying high doses and/or high intensities to biological tissue.

In addition, the inconstancy of the laser output has proved to be problematic in previous trials. True pulsed infrared lasers are notorious for loss of output power when they heat up after some time. Therefore, the manufacturer of the system for use in the present proposed trial constructed a very heavy duty probe incorporating an adequate and efficient internal cooling system. In tests the output remained constant within a $1 \%$ margin for over half an hour. ${ }^{9}$ Since the actual irradiation takes 200 seconds only, this seems quite satisfactory.

To err on the safe side and hopefully not to miss the effect of laser therapy we have opted for two doses: a low dose of $0.5 \mathrm{~J} / \mathrm{cm}^{2}$ and a high dose of $5 \mathrm{~J} / \mathrm{cm}^{2}$; both to be reached in 200 seconds.

Before, during and after the trial the laser output will be checked by an independent party using a calibrated power meter.

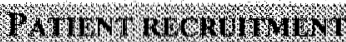

Patients with an acute lateral ankle sprains who report to the Accident and Emergency department of the Department of Surgery of the University Hospital of Maastricht are considered potential candidates to enter the trial.

Exclusion criteria are based on the following arguments. Patients for whom effect modification is likely to influence outcome are excluded. Therefore, patients who have been treated with LLLT previously are excluded. Also excluded are patients with an ankle sprain that occurred less than a year ago, patients with previous ankle sprains that were surgically treated, multiple trauma patients; patients who are not able to walk properly because of inadequate lower limb function, and patients with congenital laxity of the joints. Patients over 65 years of age are also excluded because of possible degenerative processes in the joints and therefore possible delayed recovery compared to other participants in the trial. Finally, patients are excluded if they present with an ankle injury older than 48 hours, since laser is believed to be most effective in fresh injuries and also for the sake of a comparable timing of the beginning of the intervention.

A second argument for exclusion are contraindications. Patients who present with fractures or open skin lesions or who are suspected of having tumours or systemic diseases are excluded. Patients are also excluded if they are younger than 18 years of age, because of non-closed growth discs. Exclusion on ethical grounds is applicable if no informed consent is obtained or if the injury is considered to be too mild. In addition, in very mild injuries laser is thought not to be able to prove its potential effects.

Practical reasons for exclusion apply to patients who live too far away from the hospital, or who are suspected of being unable to attend all therapy sessions (e.g., going on holliday, working abroad).

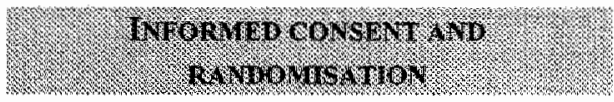

When a patient meets the entry criteria, the informed consent procedure will be completed. The patient will sign a letter that provides all the relevant information on the study including the $33 \%$ chance of receiving a placebo laser treatment. The outcome of interviews and physical examination will be 
recorded, and the patient will fill out a questionnaire to provide baseline data. After that, randomisation will take place, using a computer generated random sampling set obtained from a blinded statistician.

Prestratification by severity of injury (mild versus severe) and sports participation (does or does not participate in sports activities) will be performed to prevent unequal distributions by chance for these important prognostic factors between the treatment groups. The random permuted block size is three. The patients are then randomly allocated to three groups receiving either laser treatment with a high laser dose, laser treatment with a low laser dose or placebo laser treatment. All groups will receive a basic standardised treatment regimen. The study design is presented in figure 2 .

Figure 2: Study design.

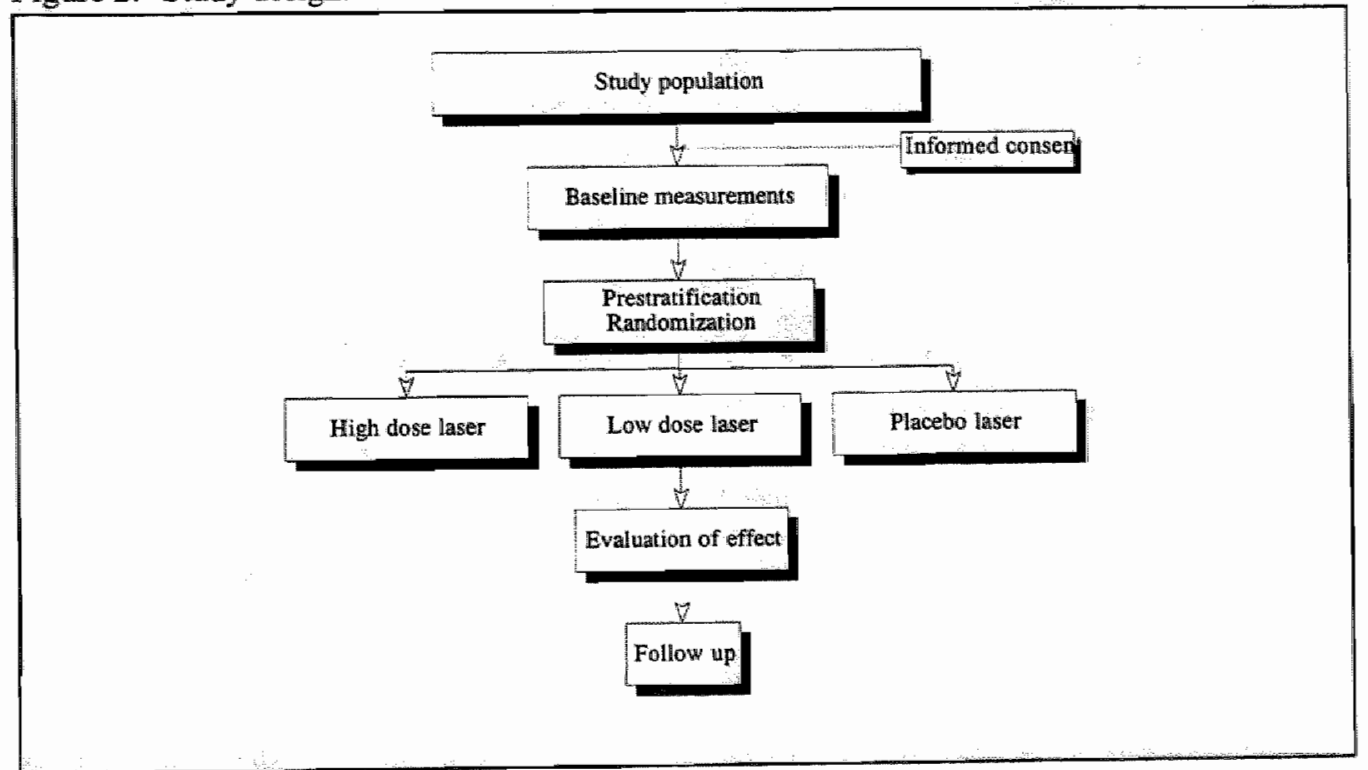

\section{Shiplit size}

The study aims at enrolling 225 patients, divided over three treatment groups of 75 persons. Group size was determined on the results of a pilot study ${ }^{29}$ In this pilot study, after five days the laser group showed $20 \%$ more pain relief than the placebo group, and $33 \%$ more pain relief than the control group. To be able to reproduce a $20 \%$ pain relieving effect, with a power of $80 \%(1-\beta)$ and a two tailed level of significance $(\alpha)$ of $5 \%$ $(p=0.025)$, between the laser group and the placebo group, group size was calculated at 50 persons. In view of what we perceived to be clinically relevant effects, we have opted for a large trial with 75 persons per group.

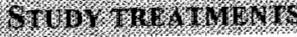

The standardised treatment consists of four days elastic wrapping followed by three and a half weeks of bracing with a Push ankle brace. We will also provides standardised patient information and standardised home exercises. The home exercises consist of 
simple mobility exercises for the ankle, relearning to take weight on the injured foot, and later on to regain balance and ensure a proper gait pattern.

The additional $904 \mathrm{~nm}$ laser therapy will be similar in all three groups except for the dose. The laser apparatus to be used is a Uniphy Phyaction $796^{\circ}$, with a peak power of 25 Watts, a pulse duration of $200 \mathrm{nsec}$ and a circular beam profile with an effective irradiated area of $6.4 \mathrm{~mm}^{2}$. The laser dose in group one will be $0.5 \mathrm{~J} / \mathrm{cm}^{2}$, the laser dose in group two will be $5 \mathrm{~J} / \mathrm{cm}^{2}$ and group three will be treated with a nonexistent laser beam (placebo).

The target tissue is considered to lie maximally $1 \mathrm{~cm}$ under the surface of the skin. Energy density at tissue level is calculated to be $0.07 \mathrm{~J} / \mathrm{cm}^{2}, 0.7 \mathrm{~J} / \mathrm{cm}^{2}$ and $0 \mathrm{~J} / \mathrm{cm}^{2}$ for each dose, respectively. Laser output will be validated before the start of the trial and will be checked at three monthly intervals during the trial. ${ }^{.}$

The three output levels will be randomised over 21 settings of the apparatus. Each patient will receive a treatment code ranging from 1 to 21 , which he or she will keep throughout the intervention period. We will randomise the settings on the apparatus in order to minimise speculation on effectiveness, as well as not having to stop the trial in case of unexpected unmasking of one of the settings. In the unfortunate event of unmasking there will still be 20 settings left to complete the trial.

The target location will be considered to be the most painful area on the lateral side of the ankle as indicated by the patient and checked by means of a pressure gauge. This will be circled with a water proof marker during the first visit. Before applying laser therapy, the area will be cleaned with alcohol $(96 \%)$ to minimise backscatter and reflection from fatty skin. Then the probe will be placed in the centre of the circumscribed area, directly on the skin, thereby preventing energy loss due to divergence and minimising reflectance loss from the stratum comeum. All groups will be following the same treatment schedule: 5 treatment sessions in the first week, 3 treatment sessions in the second week and 2 treatment sessions per week in the third and fourth week. Thus, twelve treatment sessions in total will be followed.

At each treatment session every patient will receive 200 seconds of laser therapy. Both patient and therapist will be fully blinded. In all three groups the laser apparatus will produce a soft sound and a display will read "warning: laser beam active!". Both patient and therapists will also wear protective glasses. After therapy the patient will replace his or her brace or elastic wrapping.

\section{GurGomid MASBRES}

In this trial we consider the most important outcome measures those that are capable of reflecting the actual state of the complaint from the patients' point of view. Therefore we have opted for subjective measurements as the primary measure of effect. Quick pain relief and hastened functional recovery are most prominently reported as the major effects of LLLT in soft tissue injuries. ${ }^{1,3}$ Therefore, primary measures of effect are (i) change in perceived pain measured on a visual analog scale (VAS) (10,31 $^{30}$ and (ii) speed of functional recovery measured on a function scale. ${ }^{32}$ Both measures of effect are validated and have already proven their eligibility. ${ }^{31,32}$ As secondary measures of effect the following items will be measured; 
- subjective recovery on a 11 point scale (range $0-10$, where 0 represents no recovery and 10 total recovery), ${ }^{29}$

- limitation in Activities of Daily Living (ADL) on a 11 point scale (range $0-10$, where 0 represents totally limited in $A D L$ and 10 no limitation in $A D L, ?$

- validated measurement of swelling of the ankle by means of volumetric difference at intake and at several points in time during the intervention, ${ }^{33}$

- validated pressure threshold test (in $\mathrm{kg} / \mathrm{cm}^{2}$ ) by means of an algometer,

- clinical evaluation by a blinded doctor on the basis of a standardised interview and a physical examination, ${ }^{32}$

- moment of re-uptake of sports (measured in days since the onset of trauma),

- total days of sick leave from work, school or housekeeping due to ankle trauma (measured in days since the onset of trauma),

- measurement of satisfaction about recovery rate and received treatment on a 11 point scale (range $0-10$, where 0 represents not satisfied and 10 totally satisfied),

- measurement of number of relapses during the one year follow-up.

Table 1: Timing of the measures of effect

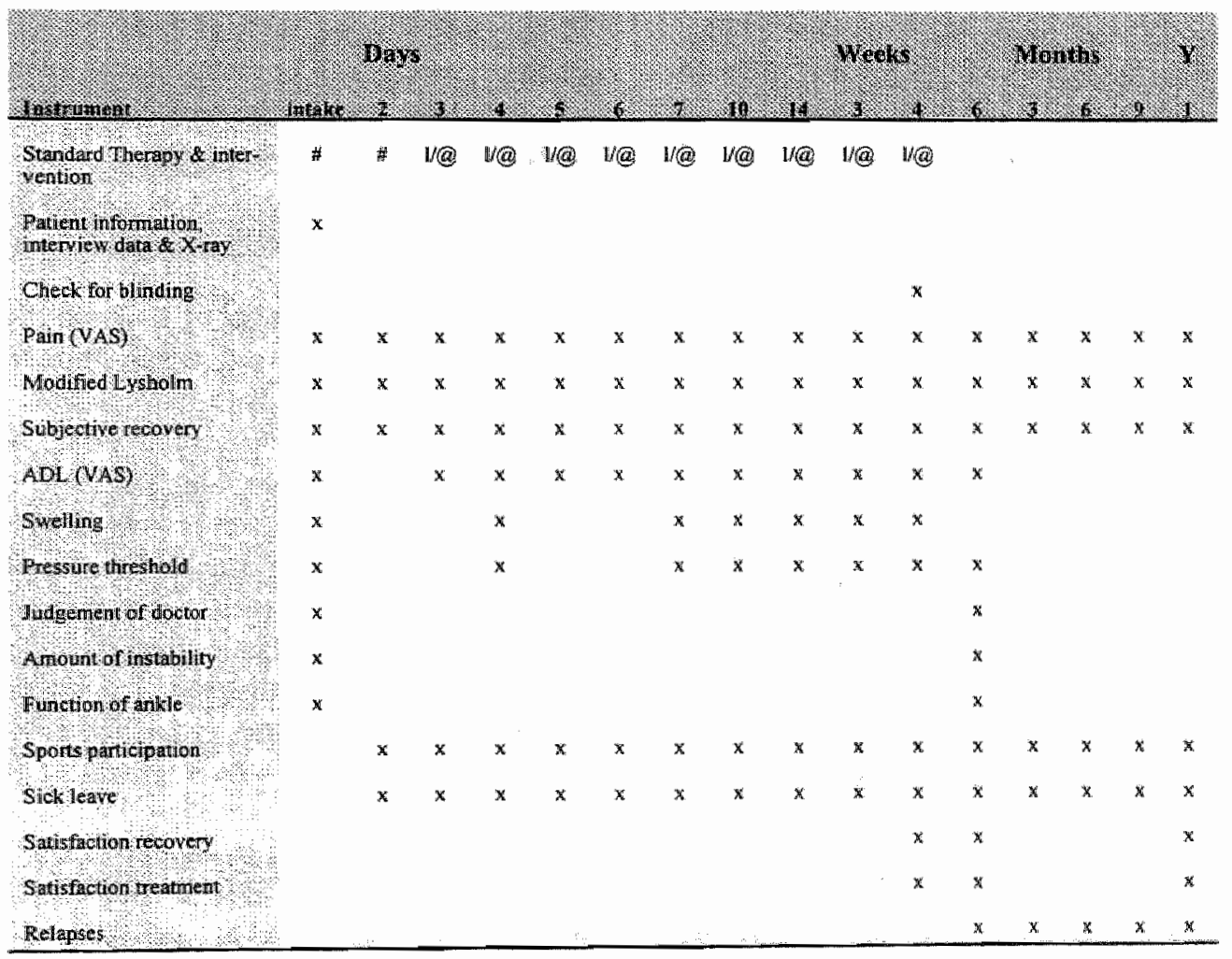

4. standard treatment; 1 laser therapy; @ brace 


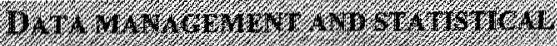
4.6.1.5. 15

Data will be stored on a personal computer in dBASE IV "The data entry routine has already been tested and used for storing data from diagnostic trial on ankle sprains. ${ }^{32}$ Data will be checked for completeness, inconsistencies and for the range of possible values. Subsequently, the data will be further analysed with SPSSWIN/PC ${ }^{\mathrm{TM}}$ : ${ }^{35}$ Analysis will be perfomed in a blinded manner; the identity of the three treatment groups will only be revealed after the final analysis has been carried out.

Prognostic comparability of baseline characteristics among the three study groups will be assessed critically for age, first-aid measures taken, level of sports participation and work setting by an independent team of experts in a blinded fashion. In addition, outcome and relevancy of the effects will be assessed before blinding is broken.

Two data sets will be prepared; an intention to treat set and a per protocol set. For the intention to treat set missing data will be substituted with the last known data per patient.

Primary analysis will be done by means of analysis of variance. In case of significant differences between groups, secondary analysis will be performed by means of Student t-tests.

Short term and long term analyses will be performed. For the short term the outcomes of interest are change in perceived pain and functional recovery. The differences between groups at five, ten and fourteen days will be regarded as the primary endpoints. Additionally, resumption of work and sports activities, as well as swelling and pressure threshold tests and patient satisfaction will be analysed for the short term results. Finally, a check for blinding will be carried out.

For the long term follow up (one year) the emphasis will be placed upon functional recovery, re-uptake of work and sports activities. Also the number of relapses will be analysed. The onset of the first relapses will be used to compare groups by means of a survival analysis model.

In the event of a positive outcome a costeffectiveness calculation will also be made. Change in perceived health status, change in medical consumption and change in work absenteeism are regarded as important outcome measures. They will be related to direct medical costs such as personal and materiall costs. It will be interesting to relate effects in laser and placebo treatment groups separately to the cost of treatment.

\section{Breussion}

There have been a number of trials on the efficacy of LLLT and soft tissue injuries. However, these studies have been criticised for methodologic and dosimetric flaws, as mentioned in the introduction. The lack of power from previous studies is to be tackled by having a large sample size. Here we aim at having three groups, each containing 75 patients. If reported effects from the pilot study ${ }^{29}$ prove to be consistent, the results should be reproducible with a two-sided alpha of 0.05 and a power of $80 \%$ in groups of 50 patients each.

If the results of the pilot do not hold, we feel that the credibility and clinical relevance of LLLI will be questionabie, and think that larger trials than this one will not be a logical next step. 
The only reason for large groups is the necessity of being able to detect relapses. In the literature $e^{36,37,38}$ the number of relapses is estimated at about $30 \%$ within one year. Should laser prove effective, a reduction of $50 \%$ in the number of relapses is thought to be clinically interesting. If these effects exist, it can be shown with a one-sided alpha of 0.05 and a power of $80 \%$ with 75 patients per group. Consequently, if we expect improvement, one-sided testing seems feasible.

From another point of view it is also concievable that if low level laser therapy indeed provides quick pain relief, it does not automatically imply that recovery will follow at the same pace. People who feel free of pain will possibly undertake activities which might be unwise from the perspective of ligamentous repair processes. Therefore, relapses can also be regarded as a measure of effect in the negative direction.

The comparison of low and high doses will hopefully show which is the most effective. If it turns out that neither dose is more effective than a placebo, we will conclude that (1) LLLT is not effective in the treatment of ankle sprains and (2) there seems to be little reason to apply LLLT on soft tissue injuries, since we expect the assumed working mechanisms to be the same for all soft tissue injuries.

Another problem in previous studies was the lack of adequate dosimetric descriptions. ${ }^{8}$ In this study we state an explicit dose at skin level and at tissue level. We will control for adequate output of the laser device throughout the trial.

\section{ReFerence}

1 King PR. Low level laser therapy: a review. Physiotherapy Theory and Practice 1990; 6:1273.8.
2 Molktar B, Baxter D, Walsh DM et al Double blind, placebo controlled investigation of the effect of combined phototherapylow level insensity haser therapy upon experimental ishaemic pain in humans. Lasers in Surgery and Medicine 1995; 17 : 74-81.

3 Beckerman H, Bie RA de, Bouter LM et al. The efficacy of laser therapy for musculoskeletal and skin disorders: A criteria-based meta-andlysis of randomized clinical trials. Physical Therapy 1992; 72: 483-91.

4 Baxter $\mathrm{OD}$. Therapeutic lasers: theory and practice. Churchill Livingstone, Edinburgh, 1994.

5 Dickersin $\mathrm{K}$, Chan $\mathrm{S}$, Chalmers $\mathrm{TC}$ et al. Publication bias and elinical trials. Contr Clin Trials 1987; 8: 343-53.

6 Galen WCC van, Diederiks J. Sportblessures breed uitgemeten (sports injuries in a broad perspecthe). De Vrieseborch, Haarlem, 1990.

7 Kitchen SS, Partridge CJ. A review of low level laser therapy. Physiotherapy, March 1991; 77(3): 161-8.

8 Bie RA de, Beckerman $\mathrm{H}$, Cuyper $\mathrm{HJ}$ de, et al. Dosis en effekt van hasertherapie; overzicht van de beschikbare therapeutische experimenten (Dose and effect of laser therapyy. Nederlands Tijdschrift voor Fysiotherapie 1991; 101 : 196-202.

9 Breugel H van. Janus Jongbloed Research Centrum, Rijksuniversiteit Utrecht, 1993.

10 Rogvi Hansen $B$, Ellitsgaard $N_{*}$ Funch $M$ et al. Low level laser treatment of chondromalacia patellae. International Orthopaedics $1991 ; 15$ : 359 61.

11 England $\mathrm{S}$, Farrell $\mathrm{AJ}$, Coppock JS et al. Low power laser therapy of shoulder tendonitis. Scand J Rheumatol 1989; 18(6):427-31.

12 Gudmundsen J, Vikne J. Laserbehandling av epicondylitis humeri og rotatorcuffsyndrom. Nor Tidsskr Idrettsmed 1987;2:6-15.

13 Meier JL, Kerkour K. Traitement liaser de la tendinite. Med et Hyg 1988; 46:907-11.

14 Vasseljen $O$, Hoeg $N_{n}$ Kjelstad B et al. Low level laser versus placebo in the treatment of tennis elbow. Scand J Rehab Med 1992; 24: 37-42.

15 Cecchereill F, Altafini L, Lo Castro $G$ et al. Diode laser in cervical myofascial pain: a double blind study versus placebo. Clin J Pain 1989; 5(4): 3014.

16 Flöter Th, Rehfisch HP. Schmerzbehandlung mit laser. Frankfurt/Main 1988. (report received after 
correspondence with authors).

17 Bithar I, Mester AR. The biostimulative effects of low level laser therapy of longstanding crural ulcers using helium neon laser, helium neon lasers plus infiared lasers, and noncoherent light: preliminary report of a randomized double blind comparatiwe study. Laser Therapy 1989; 1(2): 75 8.

18 Airaksinen $O$, Rankanen $P$, Kolari PJ et al. Effects of the infrared laser therapy at treated and non-treated trigger points. Int $\mathrm{J}$ Acup Electr Therap Res 1989; 14:9-14.

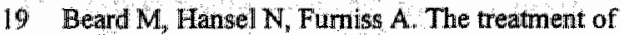
rheumatoid arthritis with low power laser. Proceedings 3 rd international physiotherapy congress Hong Kong 1990. Sydney: Link Printing Pty Ltd, 1990 .

20 Jensen $\mathrm{H}$, Harreby $\mathrm{M}$, Kjer J. Is infrared laser effective in painful arthrosis of the knee? Ugesk Laeger 1987; 149(46); 3104-6.

21 Kleîn $\mathrm{RG}$, Eek BC. Low energy laser treatment and exercise for chronic low back pain: double blind controlled trial. Arch Phys Med Rebabil 1990; 71(1): 34-7.

22 Lundeberg $T$, Haker $E$, Thomas $M$. Effect of laser versus placebo in tennis elbow. Scand $J$ Rehab Med 1987; $19: 135-8$.

23 Siebert $W$, Seichert $N$, Siebert $B$ et al. What is the efficacy of soft and mid lasers in therapy of tendinopathies? Arch Orthop Trauma Surg 1987; 106: 358-63.

24 Seichert N, Schops P, Siebert W. et al. Wirkung einer Infrarot-Lasertherapie bei weichteilrheumatische beschwerden im Doppeltblindversuch. Therapiewoche, 1987; 37: 1375-9.

25 Hansen HI, Thoroe U. Low power laser biostimulation of chronic oro-facial pain. A double blind placebo controlled cross-over study in 40 patients. Pain $1990 ; 43: 169-79$.

26 Dolan $M$, Spiker $T$, Vallkenburg $P$. Laseronderzoek. Deel 1: en experimenteel placebo onderzoek naar de invloed van een infrarood laserbehandeling op de wondgenezing bij decubitus (Experimental research into the influence of IR laser treatment for pressure ulcers). Den Haag: Haagse Hoge School 1988.

27 Gärther $\mathrm{Ch}_{s}$ Becker $\mathrm{M}$, Dill $\mathrm{H}$ et al. Analgesy by low power laser a controlled double blind study in ankylosing spondylarthritis (abstract). Laser Surg Med 1989; 1(1): 30.

28 Go PMNYH, Reed NS, Straight RC. An evansblue spectrophotometric assay to quantitative skin phototoxity. Albstract: $8^{\text {in }}$ Congress of International Society for Laser Surgery and Medicine, Taipei; ROC: November 4-7:1989.

29 Bie RA de, Steenbruggen RA. Bouter LM. Effekt van lasertherapie op inversie-traumata van de enkel (Efficacy of laser therapy in ankle sprains). Nederlands Tijdschrift voor Fysiotherapie 1988; 95: 108-12.

30 Revill SI, Robinson JO, Rosen $M$ et al. The reliability of a linear analogue for ewaluating pain. Anaesthesia 1976; $31:$ 1191-8.

31 Dixon $\mathrm{JS}_{\mathrm{w}}$ Bird HA. Reproducibility along a $10 \mathrm{~cm}$ vertical visual analogue scale. Ann Rheum Dis 1981; 40:87-9.

32 Bie RA de, Vet HCW de, Wildenberg FAJM van den, et al. The prognosis of ankle sprains. Int J Sports Med 1997; 285-9.

33 Ostelo $\mathbb{R}$, Bie RA de. Zwellingsmeting van enkels: validering wan de waterbakmethode (Validation of volumetric methods to assess swelling of ankles). Nederlands Tijdschrift voor Fysiotherapie 1997;107: 116-20.

34 George Tsu-der Chou, Edward Tiley. dBASE IV Handbook, 3rd edition, Que comporation, Carmel, 1989.

35 M. J. Norusitus. SPSS for Windows Professional Statistics, release 6.1, Illinois, 1993.

36 Bol E, Schmickli SL, Backx FJG. Sportblessures onder de knie: programmering van toekomstig onderzoek (Future research guidelines for sports. injuries prevention). NISGZ, maart 1991.

37 Editorial, Late consequences of sprained ankles. The Lancet 1991; 335: 1313-4.

38 Kannus $\mathbb{P}$, Renström $P$. Treatment for acute tears of the laterall ligaments of the ankle. J Bone Joint Surg 1991; 73A: 305-12 


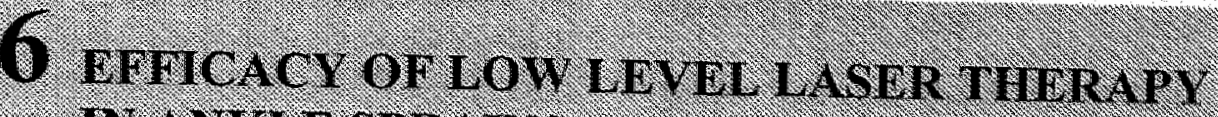 IN A NKILI SPRATNS: SHORT TERM RESULTS OF A RA NDOMISED CLIMCAL Trar
}

\author{
Robert A de Bie, MA, PT \\ Henrica $C W$ de Vet, $\mathrm{PhD}^{1}$ \\ Ton $\mathrm{F}$ Lenssen, $\mathrm{PT}^{2}$ \\ Frans AJM van den Wildenberg, $\mathrm{MD}, \mathrm{PhD}^{3}$ \\ Gauke Kootstra, $\mathrm{MD}, \mathrm{PhD}^{3}$ \\ Paul G Knipschild, MD, PhD \\ Department of Epidemiology, Maastricht University \\ 2Department of Physiotherapy, University Hospital of Maastricht \\ ${ }^{3}$ Department of General Surgery, University Hospital of Maastricht
}

\section{$4+14.4$}

Objective: To test the efficacy of laser therapy on lateral ankle sprains as an addition to a standardised treatment regimen, we conducted a trial in which high dose laser, low dose laser and placebo laser therapy were compared with each other.

Design: A randomised, double blind controlled clinical trial with a total follow up time of one year. Patients, therapists, assessors and analysts were blinded for the assigned treatment.

Setting: The trial was performed in an ambulatory care setting.

Patients: After informed consent and verification of exclusion criteria 217 patients with acute lateral ankle sprains were randomised to three groups.

Interventions: 12 Treatments of laser therapy in four weeks as an adjunct to a standardised treatment regimen of four weeks of brace therapy.

Primary outcome measure: pain as reported by the patient.

Results: Intention to treat analysis of the short term results showed no statistical significant difference on the primary outcome measures pain $(p=0.41)$ and function $(p=0.50)$, although the placebo group was slightly in favour. The placebo group performed significantly better on days of sick leave $(\mathrm{p}=0.02)$, and at some points in time for hindrance in activities in daily life and pressure pain, as well as subjective recovery $(\mathrm{p}=0.05)$. Subgroup analysis did not alter these findings.

Conclusion: Neither high nor low dose laser therapy is effective in the treatment of lateral ankle sprains. 


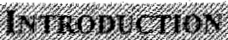

Each year $4 \%$ of the population in western countries sprain their ankle, about half of them during sports activities some $20 \%$ of these patients need medical care.

Treatment cost and absenteeism from work form not a negligible part of direct and indirect costs. About $21 \%$ of all people who have had ankle sprain injuries are absent from school or work for about 7 days. ${ }^{2}$ In addition, sports absenteeism and the emotional burden of sudden incapacitation influence a relatively simple injury negatively.

One of the new treatment modalities for ankle sprain injuries is low level laser therapy (LT), which is either used as an additional therapy, combined with taping or bracing, or as a stand-alone therapy.,4

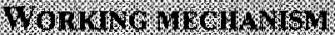

During the past 20 years, several authors have postulated biostimulative effects of $\mathrm{LT}$. Biostimulation refers to the application of electromagnetic energy by LT to body tissues, which is supposed to influence all kinds of cell functions. ${ }^{5,6,7}$ The effects are thought to consist of stimulation or inhibition of biochemical, physiological and proliferative activities. Since both stimulation and inhibition seem possible, one also refers to bio-effects of $L T$. The magnitude of the effect is reported to be dependent on wavelength, dosage and dose-intensity of L T.

One theory which attempts to explain bioeffectivity of LT claims that, in the event of an impairment or disorder, the energy state of a cell is changed, consequently altering the electromagnetic communication between cells. Laser therapy is thought to influence this communication favourably.",to

Photochemical theory offers an alternative explanation. The absorption of laser light takes place in tissue chromophores (photo acceptors). These chromophores may either be enzymes, membrane molecules or any other cellular or extracellular substances. Activation of these chromophores by LT is considered responsible for the postulated bioeffects:"

Neither theory has been thoroughlly confirmed in research; the supposed working mechanism remains therefore unclear. Moreover, recent research on tissue samples, using various dosages, have failed to show any effects on cell metabolism, and hence has not provided corroborative evidence. ${ }^{12}$

The lack of a convincing biological background explaining the clinical effects induced by LT not only hampers further explanation, but also generates uncertainties about proper dosage and treatment indications.

In a preliminary trial ${ }^{13}$ with 38 patients, LT was found to have substantial pain relieving qualities. After five days the laser group showed $20 \%$ more pain relief than the placebo group. To reproduce these results, with a power of $80 \%(1-\beta)$ and a two tailed level of significance $(\alpha)$ of $5 \%$, we would need 50 persons per group. In view of what we perceived to be clinically relevant effects, we opted for a larger trial with 75 persons per group.

\section{D1\% 16}

We compared the effects of high dose LT and low dose LT with that of a placebo in patients with an acute lateral ankle sprain. LT acted as an additional therapy, applied upon a standardised treatment regimen which consisted of four days elastic wrapping followed by three and a half weeks of bracing 
with a Push ankle brace. Efficacy was evaluated on the basis of four and six week results and three, six, nine and twelve month results. The four week follow up period was intended to reflect the actual healing process, and to provide preliminary information about resumption of work and sports participation. Follow up to one year was carried out to detect long term effects and possible relapses. In this article we present results up to four weeks as short term results.

The study was approved by the medical ethics committee of Maastricht University and the University Hospital of Maastricht (the Netherlands). A detailed description of the protocol can be found in chapter 5 of this thesis.

\section{SELECHONORT T TIENRS}

Patients who reported to the Accident and Emergency department of the University Hospital with an acute lateral ankle sprain, who were between 18 and 65 years of age and whose injury was not older than 48 hours, were selected by the doctor on call. Patients who had had an ankle injury in the preceding year, or those patients who had received previous ankle surgery were excluded. In addition, patients with fractures (confirmed by obligatory radiography), direct open trauma and underlying abnormalities of the foot and/or legs were excluded. Finally, those with systemic diseases (e.g. rheumatoid arthritis or diabetes) and mental handicap were excluded, as well as people with difficulties with the Dutch language. Patients could also be excluded for practical reasons, for instance if they lived too far away or if they could be expected not to attend all therapy sessions (e.g., going on holiday, work abroad).

Eligible patients were given a detailed description of the intended treatment procedure, and were informed about the chance of receiving a placebo therapy as well as having a right to withdraw from the trial at any time. After receiving this information in writing, the patients gave their informed consent to participate. The following morning they were seen by a trained research assistant who checked inclusion and exclusion criteria. The research assistant also kept a record of the baseline interview and physical examination and the patient filled out a questionnaire to provide baseline data.

\section{RowooNis riro:}

Patients were stratified by severity of injury (mild versus severe) and sports participation (does or does not participate in sports activities) to prevent unequal distributions by chance for these prognostic factors between treatment groups. ${ }^{14}$ After informed consent, 217 consecutive patients were randomly allocated to one of three groups by means of a computer generated table, with a random permuted block size of three. The first group $(n=74)$ received laser therapy with a low: dose, the second group $(n=72)$ received laser therapy with a high dose and the third group $(n=71)$ received placebo laser therapy. Patients, therapists, outcome assessors and analysts were blinded for the treatments given.

\section{Nmerutrioss}

All patients received a standardised treatment regimen, which consisted of four days elastic wrapping followed by three and a half weeks of bracing with a Push ankle brace. We also provided standardised patient information and standardised home exercises. The home exercises consisted of simple mobility exercises for the ankle, learning to bear weight on the injured foot, and later on to 
regain balance and ensure a proper gait pattern:

The additional $904 \mathrm{~nm}$ laser therapy was similar in all three groups except for the dose. The laser apparatus delivered a peak power of 25 Watts, a pulse duration of 200 nsec and a circular beam profile with an effective inadiated area of $6.4 \mathrm{~mm}^{2}$. Laser dose at skin level in the low dose group was $0.5 \mathrm{~J} / \mathrm{cm}^{2}$, in the high dose group $5 \mathrm{~J} / \mathrm{cm}^{2}$ and $0 \mathrm{~J} / \mathrm{cm}^{2}$ in the placebo group.

The target tissue was considered to lie at a maximum of $1 \mathrm{~cm}$ under the surface of the skin. Energy density at tissue level was calculated to be $0.07 \mathrm{~J} / \mathrm{cm}^{2}, 0.7 \mathrm{~J} / \mathrm{cm}^{2}$ and 0 $\mathrm{J} / \mathrm{cm}^{2}$ for each dose, respectively. Laser output was validated before the start and at the end of the trial and was checked at regular intervals during the trial.

The most painful area on the lateral side of the ankle was chosen as target location. The patient indicated the painful area. This was consequently checked by means of an algometer. The target area was circumscribed with a water proof marker during the first visit. Before applying laser therapy, the area was cleaned with alcohol $(96 \%)$ to minimise backscatter and reflection from fatty skin. Then the probe was placed perpendicularly in the centre of the circumscribed area, directly on the skin, thereby preventing energy loss due to divergence. All three groups followed the same treatment schedule: 5 treatment sessions in the first week, 3 treatment sessions in the second week and 2 treatment sessions. per week in the third and fourth week. Thus adding up to twelve treatment sessions, during a four weeks intervention period.

At each treatment session every patient received 200 seconds of laser therapy. Both patient and therapist were fully blinded. In all three groups the laser apparatus produced a soft sound and the display read "warning: laser beam active!". Both patient and therapists also wore protective glasses. After therapy the patient replaced his or her brace or elastic wrapping.

We allowed patients to take standardised pain medication (Paracetamol, $500 \mathrm{mg}$, maximum dosage one tablet every four hours). These drugs were provided at intake, and the patients kept a record of the amount they took.

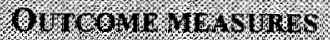

In this trial we considered the most important outcome measures those that were capable of reflecting the actual state of the complain: from the patients point of view. Therefore, the primary measures of effect were perceived pain measured on a 0 to 10 point scale and function. For measuring pain we specifically chose a 0 to 10 point scale because this way of grading pain is familiar and easy to use by patients and other assessors. Moreover it is quite similar to the Dutch report-mark system. Numerical rating scales, with a range from 0 - 10 points, provide reliable and consistent measures of clinical pain intensity when compared to VAS, both in acute as well as chronic pain measurements. $14,15,16$

The idea for a function scale was derived from the Lysholm score and adapted to ankle sprain injuries. Originally, the Lysholm score was developed for patients with knee problems. It measured the patients capability of performing activities of daily life when assessing function in relation to level of complaints. When considering the functions of the lower limb, items such as weight bearing, pain on function and instability are quite similar for the anikle as for the knee. Therefore we decided to use these items for the original Lysholm scale and added swelling and gait pattern. The thus developed contruct has been developed further with the 
use of Guttman scaling techniques to give proper weights to the various items. After that it was validated by clinical experts (content validity). Consequently, it was tested in a pilot sample of 35 patients and the present study provided the material for further validation on 217 patients.

Secondary outcome measures were total days of sick leave from work, school or housekeeping due to trauma and moment of reuptake of sports (measured in days since the onset of trauma). We also measured hindrance in limitation in Activities of Daily Living (ADL) on a 0 to 10 point scale, swelling of the ankle by means of the volumetric difference between swelling at intake and at several points in time during the intervention, pressure threshold test (in $\mathrm{kg} / \mathrm{cm}^{2}$ ) by means of an algometer, ${ }^{17,18}$ subjective recovery on a 0 to 10 point scale and satisfaction about recovery rate and received treatment on a 0 to 10 point scale.

Success of blinding, side effects and relapses were evaluated at the end of the intervention period. All measurements were carried out in a blinded fashion by means of a standardised protocol.

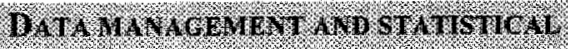 1.1.1.15}

Data were stored on a personal computer in dBASE IV TM/9 and were checked for completeness, inconsistencies, for the range of possible values and for protocol deviations. Subsequently, the data were analysed with SPSSWIN/PC $^{\text {TM }}$ statistical software. ${ }^{20}$ Analysis was performed in a blinded manner and according to the intention to treat principle: all participants, including those with poor compliance and those who had withdrawn from therapy, remained in the group to which they were assigned by randomisation. Subsequently, a per-protocol analysis was performed to see whether protocol deviations influenced the results.

The primary and secondary outcome measures were compared between the three treatment groups. Differences between the means of groups at $5,10,14$ and 28 days, respectively, were compared by using a twotailed ANOVA model. The decrease in the primary outcome measure pain was compared between the groups by regression analysis. For each patient the individual curve was estimated, where after mean group scores of the estimated regression coefficients were compared by using ANOVA.

Subgroup analyses were carried out to determine whether particular subgroups showed other outcomes than the treatment groups as a total. Dichotomised subgroups were formed according to age (cut-off: 35 years), sports-participation (yes/no), gender (female/male), job (sitting/standing work). The coding was broken after final analyses had been carried out.

\section{Results}

From September 1, 1993 till December 31, 1995,217 consecutive patients were included and randomised. All patients were present for baseline measurements; yet, $2.1 \%$ of all treatment sessions were missed and thus formed gaps in the data set (43 out of 2064 treatment sessions; $0.4 \%$ from the low dose group, $0.7 \%$ from the high dose group and $1 \%$ from the placebo group). Three categories of missings were detected.

Seven patients missed only one treatment session due to illness or work. These missings were substituted by the mean value of preceding and following measurements in the data-set in both intention to treat as well as per-protocol analyses.

Eight patients missed 21 treatment sessions because (they fell) they were cured. For these 
patients the last known entry was substituted for the intention to treat analysis. Two of these patients belonged to the low dose group, one patient to the high dose group and 5 patients belonged to the placebo group. Three patients withdrew from the trial without being cured. These were two patients from the low dose group: one patient missed two treatment sessions in a row and the other stayed away 10 days after trauma; one patient from the high dose group stayed away 8 days after initial trauma. For these patients the last known value was substituted for the intention to treat analysis.

The three treatment groups were similar with respect to demographic characteristics and baseline measures, although age and gender differed slightly in the high dose group, compared to the other two groups (Table 1).

Table 1: Comparison of treatment groups with respect to demographic and prognostic variables

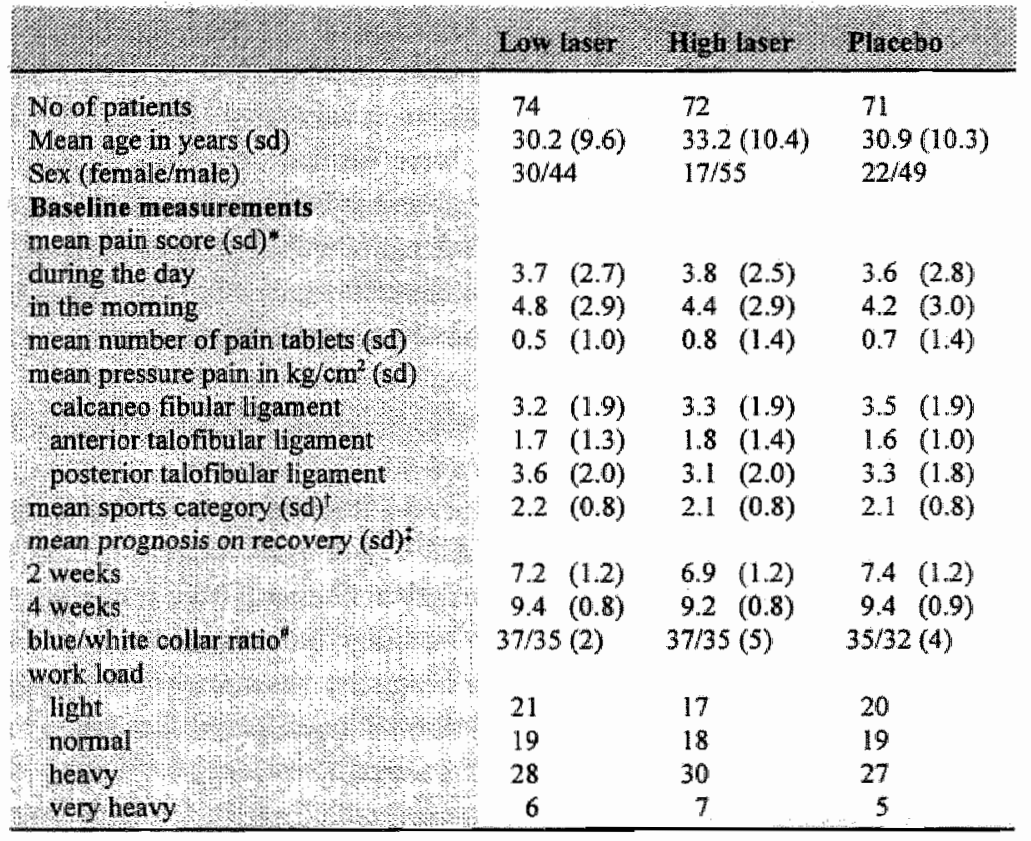

* measured on a 0 to 10 point scale ( 0 no pain, 10 extremely painful)

+ measured on a 4-point scale ( 0 no sports participation, 1 recreational, 2 competition sports, 3 professional)

* measured as a report mark (0 not recovered at all, 10 fully recovered)

* numbers between brackets indicate unemployed persons

Figure 1 shows scores of the groups for 'pain during the day". All treatment groups improved, and, the placebo group showed consistently more improvement from day 8 onward compared to the other groups.
However, comparison of the entire curves using regression analysis showed no significant differences between the three groups $(p=0.41$ ). 
Figure 1: Daily pain score of the treatment groups for four weeks; $(0=$ no pain, $10=$ extremely painful)

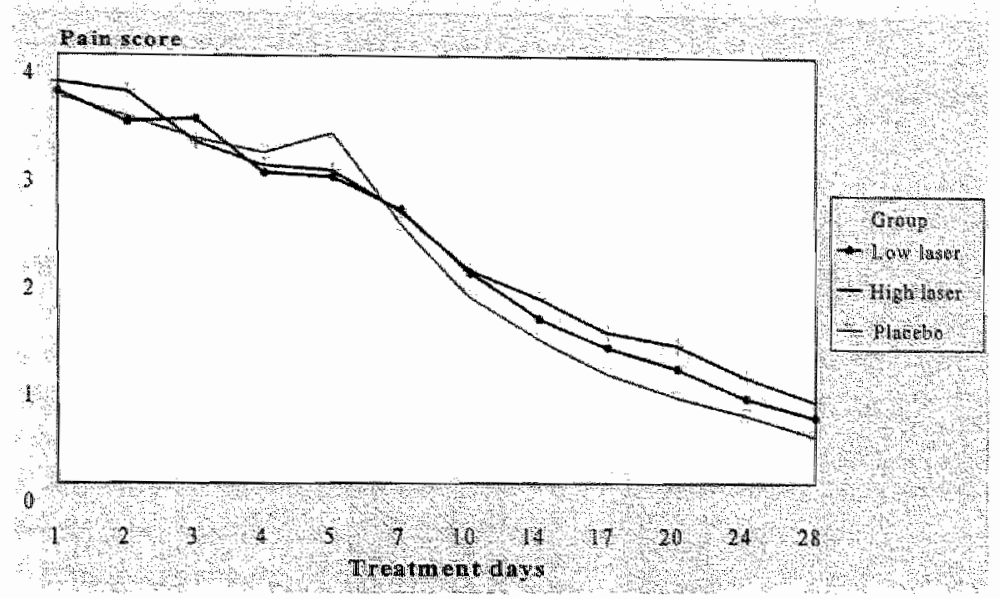

Table 2 provides information about recovery on primary and secondary measures of effect.

As can be seen from the table the outcomes on function score on day 10 and 14 , days of sick leave, hindrance in ADL on day 10 , pressure pain on anterior talofibular ligament on day 14 and subjective recovery reach statistical significance. In all these cases the placebo group performs better than the laser groups.

No side-effects of laser therapy were reported or observed during or after treatment.

The per-protocol analysis showed similar results. Analysis for success of blinding showed that placebo laser therapy was not unmasked by the patients (see Table 3).

Subgroup analyses revealed no difference in outcome for age (cut-off: 35 years), sportsparticipation (yes/no), gender (female/male), job (light/heavy work).

\section{D15 0 US $10 \mathrm{~K}$}

In this study we tried to overcome flaws encountered in a systematic review of 36 randomised trials of $L T{ }^{21}$ Attention was paid to prognostic comparability at baseline level, group size and blinding of the entire procedure. Furthermore, explicit details were given about dose and intensity of LT. An independent party checked for adequate dosimetric output of the laser device before, during and after the trial.

In this trial we compared a low dose, a high dose and placebo group. To determine whether the claimed effects of LT were present we incorporated a placebo group, as new technologies are known to be surrounded by novelty effects, and thus have the potential of enhancing placebo responses. We opted for a low dose and a high dose group because of the ongoing debate on adequacy of the dose. The low dose represented a dose and intensity 
Table 2: Measures of effect (mean and standard deviation) on several days during treatment and $P$-values of differnces in means using ANOVA.

\begin{tabular}{|c|c|c|c|c|c|c|c|c|}
\hline & & 180 & 1 & 19g & 6.8. & 19.6. & 60 & 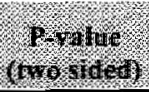 \\
\hline Perceved pain (mean,sa)@ & day 5 & 2.8 & $(2.2)$ & 2.9 & (2.1) & 3.3 & (2.4) & 0.60 \\
\hline & day 10 & 2.0 & $(2.0)$ & 2.1 & $(1,9)$ & 1.7 & (1.9) & 0.48 \\
\hline & day 14 & 1.6 & $(1.9)$ & 1,7 & (1.7) & 1.4 & $(1.7)$ & 0.42 \\
\hline & day 28 & 0.6 & $(1.0)$ & 0.8 & (1.2) & 0.4 & $(1.0)$ & 0.14 \\
\hline Tunction score* & day 5 & 25.11 & $(15)$ & 24.7 & $(15.1)$ & 25.70 & (14.8) & 0.92 \\
\hline & day 10 & 42.2( & (16.1) & 44.1 & 14.9) & 49.9( & $(15.9)$ & 0.01 \\
\hline & day 14 & 56.3( & (16.1) & 56.0 & $(15.7)$ & 60.00 & (17.1) & 0.03 \\
\hline & day 28 & 73.6 & $(14.7)$ & 74.3 & $(17.5)$ & 76.40 & 14.9) & 0.5 \\
\hline Days of sick leave (mean, sd) & & 12.5( & (11.1) & 11.2 & $(10.0)$ & 7.8 & $(9.2)$ & 0.02 \\
\hline Re uptake of sports in mean days (sd) & & 27.3 & $(7.9)$ & 27.4 & $(7.5)$ & 25.3 & $(9.8)$ & 0.26 \\
\hline Hindrance in ADI (mean sd)O & day 5 & 4.4 & (2.6) & 4.9 & $(2.8)$ & 4.8 & $(2.7)$ & 0.42 \\
\hline & day 10 & 3.7 & $(2.7)$ & 3.3 & (2.4) & 2.6 & $(2.2)$ & 0.03 \\
\hline & day 14 & 2.8 & $(2.6)$ & 2.7 & $(2.1)$ & 2.0 & $(2.1)$ & 0.08 \\
\hline & day 28 & 0.9 & (1.5) & 1.0 & (1.5) & 0.8 & (1.6) & 0.83 \\
\hline Decrease in swelling of the ankle in $\%$ & & & & & & & & \\
\hline of toral foot volume (nean, so) & day 5 & 1.6 & (2.6) & 2.1 & (2.5) & 2.0 & $(2.6)$ & 0.44 \\
\hline & day 10 & 3.5 & $(2.8)$ & 4.3 & (3.2) & 4.1 & (2.6) & 0.20 \\
\hline & day 14 & 4.4 & (2.9) & 4.8 & (3.3) & 4.9 & (3.0) & 0.55 \\
\hline & day 28 & 5.2 & (3.8) & 4.5 & (3.5) & 5.2 & (3.2) & 0.39 \\
\hline Pressure pain li kgleme (mean, so) & day 5 & & & & & & & \\
\hline on calcaneo nbular ligament & & 4.0 & (1.8) & 4.0 & $(1.8)$ & 4.0 & $(1.8)$ & 1.00 \\
\hline on anterior talofibular ligament. & & 2.3 & (1.7) & 2.4 & (1.4) & 2.2 & (1.4) & 0.71 \\
\hline on posterior talofibular liganient & & 3.9 & (1.8) & 3.9 & $(1.8)$ & 4.2 & $(1.8)$ & 0.71 \\
\hline & day 10 & & & & & & & \\
\hline on calcaneo fibular ligament & & 5.0 & $(1.4)$ & 4.8 & $(1.5)$ & 5.0 & (1.4) & 0.81 \\
\hline on anterior talofibular ligament & & 3.4 & (1.7) & 3.6 & $(1.6)$ & 3.5 & $(1.5)$ & 0.68 \\
\hline on posterior talofibuilar ligament & & 4.9 & (1.5) & 5.1 & (1.3) & 5.0 & (1.4) & 0.56 \\
\hline on calcanes fibutar ligament & day 14 & 5.3 & $(13)$ & 5.5 & (12) & 5.5 & (1) & 0.69 \\
\hline on anterior talofibular ligament & & 3.9 & (1.7) & 4.6 & (1.4) & 4.5 & (1.6) & 0.01 \\
\hline on posterior talofibular ligament & & 5.3 & $(1.2)$ & 5.4 & (1.2) & 5.4 & (1.1) & 0.65 \\
\hline & day 28 & & & & & & & \\
\hline on calcane o fibular ligament & & 5.7 & $(0.8)$ & 5.8 & $(0.7)$ & 5.7 & $(0.7)$ & 0.91 \\
\hline on anter or talofibular IIganent & & 5.3 & (1.0) & 4.9 & $(1,2)$ & 5.1 & $(1.2)$ & 0.09 \\
\hline on poster bo triofibular ligament & & 5.7 & $(0.9)$ & 5.4 & $(1.2)$ & 5.7 & $(0.8)$ & 0.32 \\
\hline Subjective recovery (mean, sd)@ & & 8.6 & $(0.9)$ & 8.7 & $(0.9$ & 8.9 & $(0.8)$ & 0.05 \\
\hline
\end{tabular}


Table 3: Succes of blinding per group

\begin{tabular}{|c|c|c|c|}
\hline 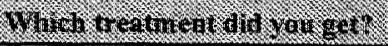 & 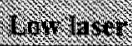 & $\operatorname{lin}(\sin )$ & Alaras \\
\hline Do nat krou & $61 \%$ & $60 \%$ & $69 \%$ \\
\hline Low dose & $21 \%$ & $19 \%$ & $13 \%$ \\
\hline Migh dose & $12 \%$ & $14 \%$ & $13 \%$ \\
\hline Placebo & $6 \%$ & $7 \%$ & $3 \%$ \\
\hline & $100 \%$ & $100 \%$ & $100 \%$ \\
\hline
\end{tabular}

used in current physiotherapy practice. Since there are claims that this dose is too low to be effective, we also incorporated a high dose group in the triall. In this fashion we would be able to determine a dose-response relationship in case of cumulative effects, an inadequate dose-response relationship in case of too low a dose, or perhaps a rebound effect in case of too high a dose. Although no adverse effects of LT were reported by the patients themselves, the outcome measures clearly showed a delayed recovery in the LT groups.

The chosen wavelength was derived from the results of previous trials. It seemed that trials on musculoskeletal diseases and sports injuries which used $632 \mathrm{~nm}$ laser showed, on average, less positive results than trials using $904 \mathrm{~nm}$ laser. ${ }^{23}$ Possibly the relative lack of penetration depth of $632 \mathrm{~nm}$ laser may have played a part in these findings, although other factors such as inadequate dosimetry may also have influenced these results. ${ }^{22}$

In a pilot study $(n=38)$ with a dose setting that was comparable to our low dose group we found LT to have beneficial effects. ${ }^{13}$ After five days of treatment the pain score appeared to have decreased significantly more in the laser group than in the placebo group. In the present investigation a slight effect of LT on decreasing pain score was also found at 5 days (see Figure 1). However, this difference was only $4 \%$, whereas in the pilot trial a difference of $33 \%$ was noted. In the present investigation, both laser groups performed less than the placebo group.

All patients were allowed to take standardised pain medication provided by us at intake. Pain medication was registered throughout the trial. It turned out that after two days of intervention almost everybody had stopped the use of medication. Moreover, drug intake was comparable between the groups. Since the differences in effect described here started to take place after five days of treatment, drug intake could not have influenced the outcome.

When considering secondary measures of effect, days of sick leave shows a worrying difference between the placebo and the laser groups. Compared to placebo a mean difference of 3.4 days for high dose laser and 4.7 days for low dose laser may be regarded highly cost-ineffective, especially when taking into account the extra medical costs of laser treatment. For the total trial it meant for the laser groups a loss of 593 working days when compared to the placebo group.

We conclude that LT is not effective in the treatment of ankle sprains. On the basis of this trial, therapists should reconsider the use of LT as an additional treatment of ankle sprains. 


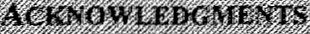

The authors would like to thank the University Hospital of Maastricht Research Fund, Uniphy bv, Push-medical and the Department of Epidemiology, Maastricht University for their financial support. We would also like to thank Maria Kerckhoffs, Margreet te Giffel, Nynke Smit and Jolanda Luime, the staff and residents of the Department of General Surgery, members of the Accident and Emergency Department and nursing staff and bandage assistants for their work, cooperation and dedication to this project. We appreciate the great help of Jos Slangen and Fons Kessels on statistical issues.

\section{Rrutratirars}

1 Galen WCC van, Diederiks J. Sportblessures breed uitgemeten (Sports linjuries in a broad perspective). De Vrieseborch, Haarlem, 1990.

2. Bol E, Schmickli SL, Backx FJG, Mechelen W van. Sportblessures onder de knie: programmering van toekomstig onderzoek (Reserach guidelines for future research in sports injury prevention). NISGZ, maart 1991.

3 Gobelet $\mathrm{C}_{x}$ Meier $\mathrm{JL}$, Volken H. 'Mid" ou 'mythe' laser et pathologie abarticulaire In: Actualitets en reeducation fonctionelle et readaptation. Simon $\mathrm{L}$. Paris: Massion, 1986.

4 Seichert N, Schops $P$, Siebert W. et al. Wirkung einer Infrarot-Lasertherapie bei weichteilrheumatische beschwerden im Doppeltblindversuch. Therapiewoche, 1987; 37: 1375-9.

5 Belkin $M$, Schwartz $M$. New biological phenomena associated with laser radiation. Health Pbys 1989; 4: 141-50.

6 Karu TI. Molecular mechanism of the therapeutic effect of low intensity laser intadiation. Laser in Life Sciences 1988; 2: 53-74.

7 Basford JR. Low energy laser therapy: controversies and new research findings. Lasers in Surgery and Medicine 1989; 9: 1-5.

8 Keijzer $M_{*}$ Jacques SL, Prahl SA et al. Light distributions in artery tissue: Monte Carlo simulations for finite laser beams. Lasers in
Surgery and Medicine 1989; 9: 148-54.

9 Diamanthopoulos C. Bioenergetics and tissue optics. In: G.D. Baxter. Therapeutic lasers: theory and practice. Churchill Livingstone, Edinburgh, 1994.

10 King PR. Low level laser therapy: a review. Physiotherapy Theory and Practice $1990 ; 6: 127$ 38.

11 Kitchen SS, Partridge CJ. A review of low level laser therapy. Physiotherapy, March 1991; 77(3): 161-8.

12 Bouma MG, Buurman WA, Wildenberg FAM van den. Low energy laser irradiation fails to modulate the inflammatory function of human monocytes and endothelial cells. Lasers in Surgery and Medicine 1996; 19 (2): 207-15.

13 Bie RA de, Steenbruggen RA, Bouter LM. Efficacy of laser therapy on lateral ankle injuries. Nederlands Tijdschrift voor Fysiotherapie 1988; 95: 108-12.

14 Price DD, Bush FM, Long S, et al. A comparison of pain measurement characteristics of mechanical wisual analogue and simple numerical scales. Pain 1994; 56: 217-26.

15 Jensen MP, Tumer JA, Romano JM. What is the maximum number of levels needed in pain intensity measurement? Pain 1994; 58: 387-92.

16 Revill SI, Robinson JO, Rosen $M$ et al. The reliability of a linear visual analogue scale for evaluating pain. Anaesthesia, 1976; 31:1191-8.

17 Kosek E, Ekholm J, Nordemar R. A comparison of pressure pain thresholds in different tissues and body regions; long term reliability of pressure algometry in healthy wolunteers. Scand J Rehab Med, 1995; 25: 117-24.

18 Reeves $\mathbb{L}$, Jaeger $B$, Graff-Radford SB Reliability of pressure algometry as a measure of myofascial trigger point sensitivity. Pain 1986; 24: 313-21.

19 Tsu-der Chou G, Tiley E. DbaseIV handbook, 3rd edition, Que corporation, Carmel, 1989.

20 Norusius MJ. SPSS for Windows Professional Statistics, release 6.1, Illinois, 1993.

21 Beckerman $\mathrm{H}$, Bie RA de, Bouter LM et al. The efficacy of laser therapy for musculoskeletal and skin disorders: A criteria-based meta analysis of randomized clinical trials. Physical Therapy 1992; 72: $483-91$.

22 Baxter GD. Low-intensity laser therapy for pain relief. In: Therapeutic lasers: theory and practice. Churchill Livingstone, Edinburgh 1994. 


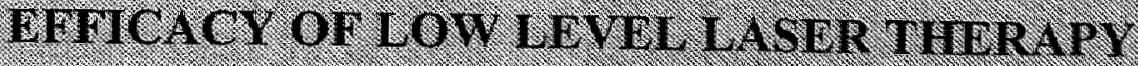 \\ IN ANRIE SPRATIS: \\ ONL YEAR RESULTS OF A RANDOMISEO CIMVICAL TRLAL
}

\author{
Robert $\mathrm{A}$ de $\mathrm{Bie}, \mathrm{MA}, \mathrm{PT}^{1}$ \\ Henrica $C W$ de Vet, $\mathrm{PhD}^{\prime}$ \\ Frans $\mathrm{AJM}$ van den Wildenberg, $\mathrm{MD}, \mathrm{PhD}^{2}$ \\ Anton F Lenssen, PT $^{3}$ \\ Gauke Kootstra, MD, $\mathrm{PhD}^{2}$ \\ Paul G Knipschild, $\mathrm{MD}, \mathrm{PhD}^{1}$ \\ 'Department of Epidemiology, Maastricht University \\ ${ }^{2}$ Department of General Surgery, University Hospital of Maastricht \\ ${ }^{3}$ Department of Physiotherapy, University Hospital of Maastricht
}

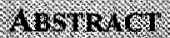

Absenteeism from work due to lateral ankle sprains is high. In the literature absenteeism from work is estimated at 7.3 days, while the one year prevalence of chronicity of these injuries ranges from $10-50 \%$. Since laser therapy is thought to be an effective means in the management of lateral ankle sprains on both the short and long term, we present the long term results of a double blind, randomised, clinical trial.

217 Patients with acute lateral ankle sprains were randomised in three groups and received high or low dose or placebo laser therapy as an addition to a standardised treatment regimen. Twelve treatments in four weeks were given, followed by long term measurements at 3, 6, 9, and 12 monthis. Patients, therapists, assessors and analysts were blinded for the assigned treatments.

Intention to treat analysis showed that total days of absenteeism from work and sports were remarkably lower in the placebo group when compared to the laser groups; ranging from 3.7 to 5.3 and 6 to 8 days, respectively. The total number of relapses in the low dose laser group $(n=22)$ was significantly higher than in the other two groups (high laser $n=13$ and placebo $n=13$ ).

We conclude that laser therapy in ankle sprains is not an effective therapy in the reduction of absenteeism from work or sports and the prevention of relapses.

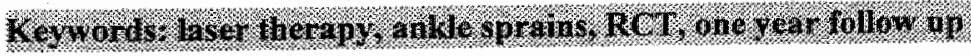




\section{4.}

Each year $4 \%$ of the population in western countries sprain their ankle, about half of them during sports activities. Some $20 \%$ of these patients need medical care. In people with a sedentary lifestyle such injuries can be painful but relatively non-disruptive. However, in people with a more demanding or athletic work setting or hobby, such injuries might have important, sometimes life-long effects.

The prevalence of chronic ankle damage after inversion trauma waries between $10-20 \%, 2,3$ and $30-40 \%{ }^{4-7}$ and even $50 \% .^{8}$ It is likely that each author defines chronic instability in his own way, and therefore obscures these findings. However, these figures are worrisome.

Absenteeism from work and school is estimated at 7.3 days per sprain ${ }^{9} 10$ while sprains are responsible for $10-15 \%$ of total absenteeism from work in the Netherlands. ${ }^{1}$

Traditionally, ankle ligament injuries are graded from I (stretch), II (partial tear) to III (complete tear). However, research shows that both partial as well as complete tears reach the same level of recovery after one year. ${ }^{11}$

In the Netherlands laser therapy (LT) is claimed to be an effective therapy in the treatment of inversion injuries of the ankle. ${ }^{12}$ On the short term it is supposed to linder pain and hasten functional recovery and therewith reduce absenteeism from work. In the long term it is expected to reduce the number of relapses and the number of chronic ankle injuries after inversion trauma. Also, one holds the opinion that high dose laser is more effective than low dose laser. ${ }^{13-1.5}$

To shed light on the above stated claims we conducted a randomised clinical trial to assess the efficacy of high dose LT versus low dose
LT versus placebo $L T$ in the treatment of patients with an acute lateral ankle sprain. LT served as an additional therapy, and was applied upon a standardised treatment regimen. Efficacy was evaluated on the basis of 4 and 6 week results and $3,6,9$ and 12 month results. The four week follow up period was intended to reflect the actual healing process, and to provide preliminary information about resumption of work and sports participation. One year follow up was carried out to detect long-term effects and possible relapses. In this article we present the $3,6,9$ and 12 month results.

The study was approved by the medical ethics committee of Maastricht University and the University Hospital of Maastricht (the Netherlands). A detailed description of the protocol can be found chapter 5 of this thesis.

\section{0.

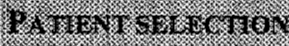

Patients who reported to the Accident and Emergency department of the University Hospital of Maastricht with an acute lateral ankle sprain, who were between 18 and 65 years of age and whose injury was not older than 48 hours, were selected by the doctor on call.

We excluded patients who had had an anklle injury in the preceding year, and patients who had received previous ankle surgery. Also, patients with radiographically confirmed fractures, direct open trauma or underlying abnormalities of the foot and/or legs were excluded, as well as those with systemic diseases or mental handicap. Patients could also be excluded for practical reasons, for instance if they had difficulties with the Dutch language, lived too far away or if they could be expected not to attend all therapy sessions (e.g., going on holiday, work abroad).

Eligible patients received a detailed descrip- 
tion of the intended treatment procedure, and were informed about the chance of receiving placebo therapy as well as having the right to withdraw from the trial at any time. After receiving this information, the patients had to give their written informed consent. The next norming a trained research assistant checked inclusion and exclusion criteria and performed the baseline interview and physical examination. The patient filled out a questionnaire to provide baseline data.

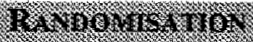

Patients were stratified by severity of imjury (mild versus severe) on the basis of a function score $^{1.6}$ and sports participation (does or does not participate in sports activities) to prevent unequal distributions by chance for these prognostic factors between treatment groups. After they had given informed consent patients were allocated at random to one of three groups by means of a computer generated table, with a random permuted block size of three. The first group received laser therapy with a low dose (LD), the second group received laser therapy with a high dose (HD) and the third group received placebo laser therapy (PD). Patients, therapists, outcome assessors and data analysts were blinded for the treatments given.

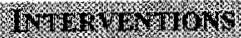

All patients received a standardised treatment regimen, which consisted of four days elastic wrapping followed by three and a half weeks

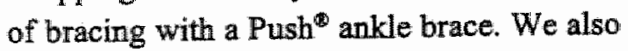
provided standardised patient information and standardised home exercises. The patient information held advice and regulation of $\mathrm{ADL}$ activities during the first few days after injury, While the home exercises consisted of simple mobility exercises for the ankle, learning the patient to bear weight on the injured foot, and later on to regain balance and ensure a proper gait pattern.

The additional $904 \mathrm{~nm} \mathrm{LT}$ was similar in all three groups except for the dose. The laser apparatus delivered a peak power of 25 Watts, with a pulse duration of $200 \mathrm{nsec}$ and had a circular beam profile with an effective irradiated area of $6.4 \mathrm{~mm}^{2}$. Laser dose at skin level in the low dose group was $0.5 \mathrm{~J} / \mathrm{cm}^{2}$, in the high dose group $5 \mathrm{~J} / \mathrm{cm}^{2}$, and $0 \mathrm{~J} / \mathrm{cm}^{2}$ in the placebo group.

The target tissue was considered to lie at a maximum of $1 \mathrm{~cm}$ under the surface of the skin. Energy density at tissue level was calculated to be $0.07 \mathrm{~J} / \mathrm{cm}^{2}, 0.7 \mathrm{~J} / \mathrm{cm}^{2}$ and 0 $\sqrt{ } / \mathrm{cm}^{2}$ for each dose, respectively. Laser output was validated before the start and at the end of the trial and was checked at regular intervals during the trial by an independent party.

The patient indicated the most painful area on the lateral side of the ankle, which was consequently checked by means of an algometer. The thus identified and verified target area was circumscribed with a water proof marker during the first visit: Next, the area was cleaned with alcohol (96\%) to minimise backscatter and reflection from fatty skin. Then the probe was placed perpendicularly in the centre of the circumscribed area, directly on the skin, in order to prevent energy loss due to divergence. All three groups received 12 treatments in four weeks; 5 treatments in the first week, 3 treatments in the second week and 2 treatments per week in the third and fourth week.

During each treatment session every patient received 200 seconds of laser therapy. Both patient and therapist were fully blinded. In all three groups the laser apparatus produced a soft sound and the display read "warning: laser beam active!". Both patient and therapist wore protective glasses. After therapy the elastic wrapping or brace was replaced. 
We allowed patients to take standardised pain medication (Paracetamol $500 \mathrm{mg}$, maximum dose one tablet every four hours). The drugs were provided at intake, and the patients kept a tecord of the amount they took during the treatment period:

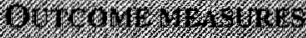

To assess the long term efficacy of LT we were interested in the total number of days of absenteeism from work, school or housekeeping due to trauma and in the moment of re-uptake of sports (measured in days since the onset of trauma). We also measured level of activity on a 0 to 10 point scale, level of complaints on a 0 to 10 point scale, function on a 0 to 100 point scale and the use of a brace during $\mathrm{ADL}$ and sports activities. The 0 to 10 point scales are quite similar to the Dutch schoolreport mark system, and therefore easy to use by the assessors. They also provide reliable and consistent measures when compared to VAS. ${ }^{16}$ The function score was validated in previous research. ${ }^{17}$

Also the number of relapses per group were measured. All long term measurements were performed by telephone by a trained research assistant. Non responders received letters which urged them to reply. Serious relapses were checked at the University Hospital by the doctor on call.

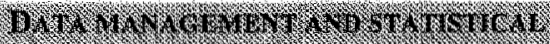

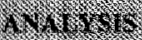

Data were stored on a personal computer in dBASE IV'TM 18 and were checked for completeness, inconsistencies, for the range of possible values and for protocol deviations.
Subsequently, the data were analysed with SPSSWIN/PC ${ }^{\text {MM }}$ statistical software. ${ }^{19}$ Analyses were performed in a blinded manner and according to the intention to treat principle: all participants, including those with poor compliance and those who had withdrawn from therapy, remained in the group to which they had been assigned by randomisation. Subsequently, a per protocol analysis was performed to see whether protocol deviations influenced the results.

The outcome measures were compared between the three treatment groups. Differences between the means of groups at $3,6,9$ and 12 months, respectively, were compared by using a two-tailed ANOVA model for continuous data or a Chi-square test for dichotomous data. The number of relapses was compared between the groups by a Cox-regression model. Differences in days of absenteeism from sports was calculated by a KruskalWallis test for non-normal distributed data. Subgroup analyses were carried out to determine whether particular subgroups showed other outcomes than the treatment groups as a total. Dichotomised subgroups were formed according to age (cut-off: 35 years), sportsparticipation (yes/no), gender (female/male), and job (heavy/light work) and job setting (blue/white collar).

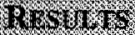

From September 1, 1993 until December 31, 1995, 217 patients were included and randomised.

The three treatment groups were similar with respect to baseline measures, although age and gender differed slightly in the high dose group, compared to the other two groups (Table 1). 
Table 1: Comparison of treatment groups with respect to demographic and prognostic variables at baseline level

\begin{tabular}{|c|c|c|c|}
\hline & 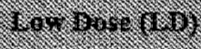 & $11 \%(1019)$ & 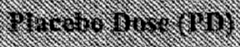 \\
\hline Nio ortier & 74 & 72 & 71 \\
\hline 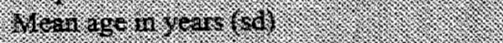 & $30.2(9.6)$ & $33.2(10.4)$ & $30.9(10.3)$ \\
\hline 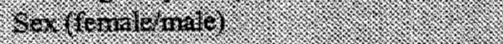 & $30 / 44$ & $17 / 55$ & $22 / 49$ \\
\hline 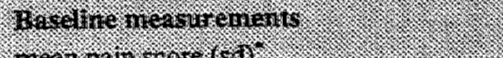 & & & \\
\hline 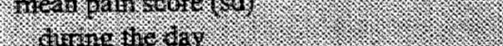 & $3.7 \quad(2.7)$ & $3.8 \quad(2.5)$ & $3.6 \quad(2.8)$ \\
\hline & $4.8 \quad(2.9)$ & $4.4 \quad(2.9)$ & $4.2 \quad(3.0)$ \\
\hline 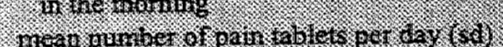 & $0.5(1.0)$ & $0.8 \quad(1.4)$ & $0.7(1.4)$ \\
\hline 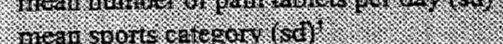 & $2.2(0.8)$ & $2.1(0.8)$ & $2.1 \quad(0.8)$ \\
\hline 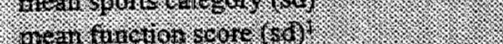 & $13.1(10.6)$ & $12.1(10.8)$ & $13.4(11.8)$ \\
\hline 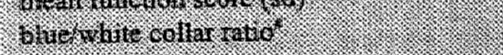 & $37 / 35 \quad(2.0)$ & $37 / 35 \quad(5.0)$ & $35 / 32 \quad(4.0)$ \\
\hline 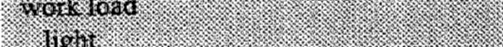 & 21 & 17 & 20 \\
\hline 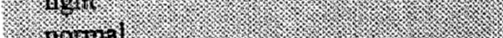 & 19 & 18 & 19 \\
\hline (romary & 28 & 30 & 27 \\
\hline 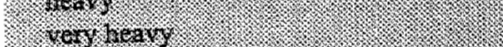 & 6 & 7 & 5 \\
\hline
\end{tabular}

- measured on a 0 to 10 point scale ( 0 no pain, 10 extremely painfiul)

- measured on a 4- point scale (O no sports participation, 1 recreational, 2 competition, 3 professional)

* measured on a $0-100$ point scale ( 0 no function, 100 perfect function)

" numbers between brackets indicate unemployed

All patients were present for baseline measurements; yet, in the follow up 3.6 to $8.3 \%$ of the patients were lost to follow up as time passed by. Table 2 shows the numbers per group as compared to the baseline attendance, as well as outcome measures at $3,6,9$ and 12 months of follow up.

The low dose group showed 6 losses to follow up after one year; 4 patients had moved, 1 patient did not respond to either written or telephonic requests and one patient's phone was disconnected.

In the high dose group 2 patients had moved and one patient had left an erratic phone number; thus 3 patients in total were missed. The placebo group showed 8 losses to follow up after one year; 6 patients had moved, one patient"s phone was disconnected and one patient had no telephone and did not react to written requests.

As can be seen from table 2 there is a striking difference between the two laser groups and the placebo group when we compare absenteeism from work and sports. Other outcome measures do not show large differences. Also correction for baseline differences on sex and age with ANOVA did not alter the results. The per-protocol analysis showed similar results.

Table 3 shows the amount of relapses per 3 months in the three groups. No patient had more than one relapse. The total number of relapses was $45(20.7-22.6 \%$, depending on comparison with number of patients at baseline attendance or at the end follow up) of which 22 occurred in the low dose group. 
Table 2: Outcome measures at $3,6,9$ and 12 months of follow up

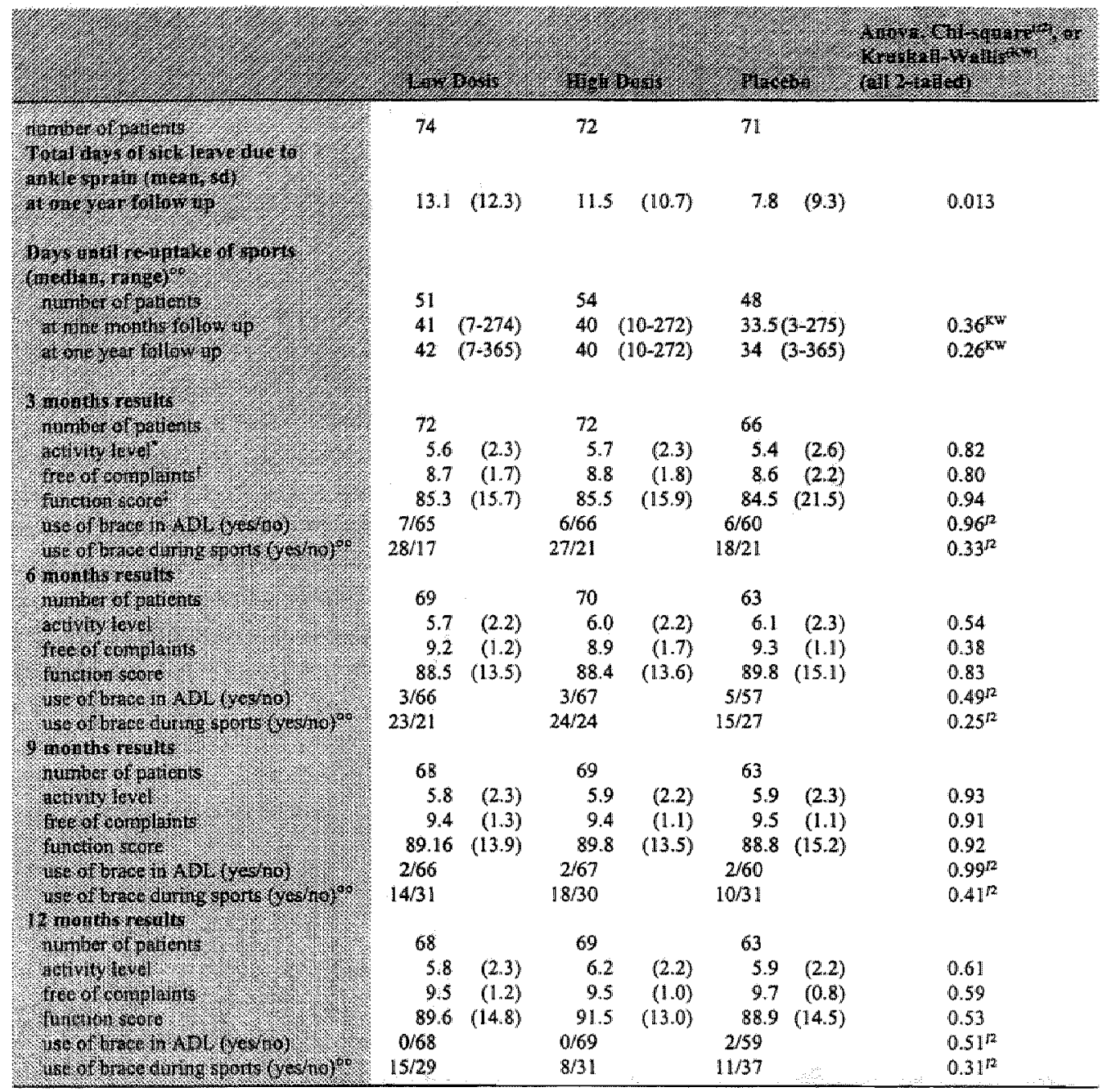

- measured on a $0-10$ point scale

t measured on a $0-10$ point report mark scale ( 10 is free of complaints)

t measured on a $0-100$ point scale ( 0 is no function, 100 perfect function)

oc only applicable in patients who participate in sports

From a Cox-regression model a significant trend $(p=0.04)$ towards a greater relapse ratio in the LD laser group compared to the HD laser group or placebo group was found.

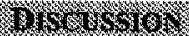

Efficacy of laser therapy is mostly studied on a short term basis, even in musculoskeletal disorders. 
Table 3: Number of relapses in the three groups at $3,6,9$, and 12 months

\begin{tabular}{|c|c|c|c|c|c|c|c|c|}
\hline 8 & $x$ & 24 & III & (2) & the & (1) & 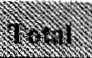 & (2) \\
\hline \multicolumn{9}{|c|}{ 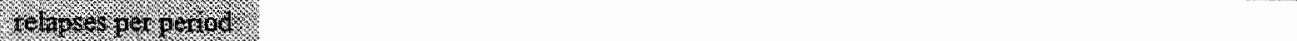 } \\
\hline trte raronitis & $11 / 72$ & & $6 / 72$ & & $5 / 66$ & & $22 / 210$ & 0.26 \\
\hline 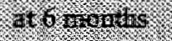 & $7 / 69$ & 18 & $2 / 70$ & 8 & $4 / 63$ & 9 & $13 / 202$ & 0.22 \\
\hline 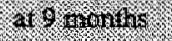 & $4 / 68$ & 22 & $2 / 69$ & 10 & $1 / 62$ & 10 & $7 / 199$ & 0.39 \\
\hline it 12 naratis & $0 / 68$ & 22 & $3 / 69$ & 13 & $0 / 62$ & 10 & $3 / 199$ & 0.04 \\
\hline
\end{tabular}

In trials studying $904 \mathrm{~mm}$ laser therapy the longest follow up periods are one year ${ }^{20}$ and 9 months ${ }^{21}$, but most study its efficacy on a rather short term basis (e.g., during and immediately after the treatment period). This is because most authors are interested in short term effects such as pain reduction and lindering of swelling. ${ }^{22,23}$

However, also long term effects are of importance. In this trial the findings on differences in absenteeism from work and sports between the laser groups and the placebo group are quite substantial, favouring the placebo treatment. Axelsen et al. ${ }^{24}$ also reported that 'patients treated with active laser had a significantly longer sick leave', although they used a laser with a wavelength of $830 \mathrm{~nm}$.

Other studies ${ }^{9,10}$ reported an average absenteeism from work due to ankle sprains of 7.3 days. The average absenteeism found in the placebo group of 7.8 days is quite comparable. This makes it more likely that the remaining difference in absenteeism is largely attributable to laser therapy. Or, to put it in another way, of the total number of days of absenteeism in this trial (2283 days), 590 days (about $25 \%$ ) could have been avoided if we had not given laser to two-thirds of the study population. The number of relapses in this trial is substantial, but to be expected. Other trials report corresponding figures. ${ }^{5.7}$ No reason can be thought of why the low dose group is responsible for half the number of relapses.
Apart from the number of relapses and days of absenteeism, we found no other differences between the three therapy groups, hinting at biological rationales. An answer in the ongoing debate on the adequacy of proper dose can therefore not be given. One could argue that the laser doses used here were suboptimal. They could be either too low, too high or both on opposite sides of the optimum dose. However, in our opinion this is unlikely. The low dose was chosen as an adequate reflection of the dosimetric principles that were known in $1994 .^{25}$ To create a therapeutic contrast we chose a high dose which was ten times higher than the low dose. This dose is nowadays used in physiotherapeutic practice as the optimal dose. The use of even higher doses in laser therapy is therefore not recommended; there is still no biological rationale for this.

The noted effects are most likely not attributable to incomparability of the study population: baseline measures, prognostic variables, work setting and workload were comparable between groups. Moreover, additional correction for baseline differences did not alter the results. Since blinding of this trial was only broken after the final data were collected, and also because during follow up the research assistant who was responsible for follow up measurements was unaware of group the allocation, it is unlikely that our findings have been biased by foreknowledge.

Hence, we conclude that these results show that laser therapy is not effective. It prolongs 
absenteeism from work and sports participation substantially, and also increases the number of relapses in the LD group. We therefore state that laser therapy has no beneficial effects in the treatment of sprained ankles.

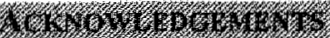

The authors would like to thank the University Hospital of Maastricht Research Fund, Uniphy bv, Push-medical and the Department of Epidemiology, Maastricht University for their financial support. We appreciate the assistance of Jos Slangen on data management.

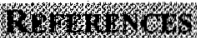

1 Galen WCC van, Diederiks J. Sportblessures breed uitgemeten (Sports injuries in a broad perspective). De Vrieseborch, Haarlem, 1990.

2 Rens ThJG. Rupturen van de laterale enkelband(en): opereren of niet? (Ruptures of lateral ankle ligaments: to sufure or not?). Nederlands Tijdschrift voor Geneeskunde, 1986; 130: 480-4.

3 Karlsson J von, Lansinger O. Chronic lateral instability of the ankle in athletes. Sports. Med 1993; 16: 355-65.

4 Freernan MAR. Treatment of nuptures of the lateral ligament of the ankle. J Bone Joint Surg 1965; $47 \mathrm{~B}(4) ; 661-8$.

5 Brostrom Lu Sprained ankles; treatment and prognosis in recent ligament ruphures. Acta Chir Soand 1966; 132:537-50.

6 Glasgow MA, Jackson AM, Jamicson P. Instability of the ankle after injury to the lateral ligament. J Bone Joint Surg 1980; 62B: 196-200.

7 Dijk $\mathrm{CN}$ van. On diagostic strategies in patients with severe ankle sprains. Thesis, Rodopi, Amsterdam, 1994.

8 Maio DE. Chronic lateral ankle instability - inversion sprains. Clinical Orthopedics 1992; 15: 87-96.

9 Bol E schmickli SL, Backx FJG, Mechelen W wain. Sportblessures onder de knie: programmering van toekomstig onderzoek (Reserach guidelines for future research in sports injury prevention). NISGZ, maart 1991.

10. Dumning AJ (ed) et al. Kjezen en Delen; advies in hoofidzaken van de commissie keuzen in de zorg, VDB 91-340, 2e druk, Den Haag, 1991.

11 Kamnus $P$, Rennström $P$. Treatment for acute tears of the lateral ligaments of the arlkle. I Bone Joint Surg 1991; 73A: 305-12.

12 Koel G. Lasertherapie voor de fysiotherapeut (Lasertherapy for the physiotherapist) Eindhoven: Uniphy, 1988.

13 Yew DT. Ling Wong SL, Chan Yau-Wa. Stimulating effect of the low dose laser - a new hypothesis. Acta Anat 1982; 112: 131-6.

14 Bellkin M, Schwarz M. New biological phenomena associated with laser radiation. Health Physics $1989 ; 56(5): 687-90$.

15 Kolari PJ. Penetration of unfocussed light into the skin. Arch Dermatol Res 1985; 277: 342-4.

16 Revill SE, Robinson JO, Rosen et al. The reliability of a linear visula analogue scale for evaluating pain. Anaesthesia, 1976; 31: 1191-8.

17 Bie RA de, Vet HCW de, Wildenberg FAJM van den, Lenssen $T$, Knipschild $P G$. The prognosis of ankle sprains. Int I Sports Med 1997; 18: 286-90.

18 Tsu-der Chou G, Tiley E. DbaseIV handbook, 3rd edition, Que corporation, Carmel, 1989.

19 Nonusius MJ. SPSS for Windows Professional Statistics, release 6.1, Illinois, 1993.

20 Longo L, Tamburini A, Monti A, Cattaneo L, Sesti AG. Treatment with $904 \mathrm{~nm}$ and $10600 \mathrm{~nm}$ laser of acute lumbago: double blind control. Laser Clinical research, 1988; 16-20.

21 Bihari I, Mester AR. The biostimulative effects of low level laser therapy of longstanding crural ulcers using helium neon laser, helium neon plus infrared lasers, and noncoherent light: preliminary report of a randomized double blind comparative study. Laser Ther 1989; 1: 75-8.

22 King PR. Low levell laser therapy. Physiotherapy Theory and Practice 1990; 6: 127-38.

23 Kitchen SS, Partridge CJ. A review of low level laser therapy. Physiotherapy, 1991; 77: 161-8.

24 Axelsen SM, Bjerno T. Laserbehandling af fodledsdistorsion. Ugesk Laeger 1993; 155: 3908-11.

25 Beckerman H, Bie RA de, Bouter LM, Cuyper HJ de, Oostendorp RAB. The efficacy of laser therapy for musculoskeletal and skin disorders, a criteria based meta-analysis of randomised clinical trials. Physical Therapy 1992; 72: 483-91. 


\section{GEMERAL DISCUSSION}

This chapter discusses the findings of this thesis. Firstly, it reflects on the evidence derived from the two systematic reviews that have been described in chapters 2 and 3 . Secondly, the feasibility of our prognostic study, described in chapter 4 , will be discussed. Finally, we will address the internal and external validity of our elinical trial, as reported upon in chapters 5 to 7 . This chapter concludes with my personal view on the efficacy of laser therapy.

\section{Revinus}

In summarising the evidence of physiotherapy trials we have encountered several problems. The quality of the studies varies widely from low to rather high. If there is no apparent relationship between methodological quality of the studies and the effect sizes, ${ }^{1}$ all studies might be included for the purposes of drawing the final conclusion. If, however, there is a relationship, it makes sense to allow only the best quality studies to have the greatest influence on final outcome. However, choices about cut-off points and the justification of omitting lower quality evidence are always arbitrary and difficult.

Physiotherapy trials often harbour a multitude of measures of effect which are hardly comparable between studies. Decisions about combining the results must ultimately rely on good sense and clinical judgement. In such cases it is important to consider whether the participants, interventions and outcomes in each of the trials included are sufficiently similar to allow for meaningful combination of outcomes. ${ }^{2}$ To date, combining measures of effect does not often apply to physiotherapy trials. That is why we placed the accent on qualitative rather than quantitative analyses of studies under review.

We performed two systematic reviews. Both used the same criteria list for assessing methodological quality. The criteria list tries to measure the internal validity, precision and relevance of the choices with respect to population, intervention and measures of effect ${ }^{3}$ and thus gives an impression of the adequacy of the performed research. The list was originally designed by Ter Riet et al., ${ }^{4}$ and modified over the years by Koes et al.," and van der Heijden et al. ${ }^{6}$ It is based on generally accepted principles of intervention research ${ }^{7}$ and has been adapted for each review with respect to the intervention and relevant outcome measures. ${ }^{3}$

In the review of conservative interventions in the treatment of acute lateral ankle sprains (chapter 2) we found the overall methodological quality to be low. Only two studies scored above 60 points, implying the methodological inadequacy of the remaining 42 trials. Of course we are aware of the fact that the quality of the reported material does not necessarily reflect the quality of the primary research. Yet these publications are the best available evidence and are our best source for answers regarding the efficacy of conservative interventions in acute lateral ankle sprains. It is especially disappointing to see that many easily avoidable errors in design, reporting and data-analyses were made. One striking finding is the reluctance (or sloppiness) to assure proper blinding. This is 
worrisome, since recent research shows that unblinded trials are bound to deliver more biased answers. Reporting is often further flawed on description of drop outs, prognostic comparability, co-interventions and side effects. In the data-analysis many trials report outcomes that are not based on between group comparisons.

Apart from the quality issue, there is the problem of adequately summarising the available evidence. The reviewed studies use different instruments to assess identical outcome measures. We therefore assessed the outcomes of all studies qualitatively. However, since pooling of effect sizes seems to be the fashion nowadays ${ }^{9}$ and reviewers are urged to do so, we also tried to pool the reviewed studies. Because of the different measurement instruments in the various studies, we used effect size calculations ${ }^{10}$ to allow for pooling of the material. However, only half of the studies allowed for effect size calculations, and were poolable in the end. Moreover, differences were found when comparing the outcomes between the qualitative and quantitative methods, still leaving uncertainty about the efficacy of the interventions studied. Although small differences between interventions were observed, no firm conclusions on the efficacy of conservative interventions in the treatment of acute lateral ankle sprains can be drawn.

For the review on $904 \mathrm{~nm}$ laser therapy (chapter 3) we found the methodological quality of these studies to be poor as well. Grosso modo the same flaws were detected as in the other review. To complicate things, laser was used on multiple indications, thus inferring a large heterogeneity in study population and measures of outcome. For these reasons, pooling of the data was impossible and we therefore used a qualitative manner of describing the results. No positive effects of laser therapy were found, although some areas seem promising. Furter in vivo and in vitro research is needed.

Both reviews showed another shortcoming of the performed research. Most studies lacked an adequate sample size, therewith introducing imprecise answers. It is possible that small positive studies were more easily published than small negative ones, thus creating publication bias. Therefore larger trials with sound methodology are called for.

\section{Procivasio}

Our research on the prognosis of ankle sprains (chapter 4) showed that despite the lack of hard diagnostic criteria it is feasible to establish a proper model for predicting the outcome on recovery in acute lateral ankle sprains just after the moment of injury. For two weeks prediction a standardised scale which measures function suffices. Not only was the accuracy of the diagnostic instrument high, it was also totally independent from imaging techniques.

We also found that pain and swelling as such are bad predictors for recovery, but related to functioning of the patient they can predict outcome rather well. Therefore, we suggest that in the future doctors only look at complaints like pain and swelling in relation to function.

We planned to validate the model in our clinical trial. However, the amount of light cases turned out to be too small to confirm our previously established modei. Proper validation of the piloted model is still called for. 


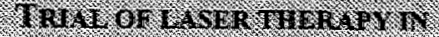

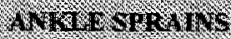

In our laser trial we tried to avoid errors in trial design as they were encountered in the reviews. In the following paragraphs we will discuss items bearing on the internal validity and the external validity of our trial.

The internal validity of a trial is ascertained by the use of proper randomisation proce-dures, blinding, avoidance of withdrawals and sufficient power

The external validity of a trial depends on the proper choice of patients, interventions and measures of outcome. In the next paragraphs these choices will be discussed.

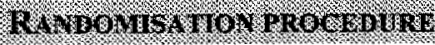

Randomisation is meant to assure comparability of the study groups for baseline characteristics. "An important feature of a proper randomisation method is the masking of the assignment procedure, therewith effectively assuring unpredictability of future assignments and the preclusion of cheating.

In our trial we used a fairly elaborate assignment method. Patients were stratified by severity of their injury and their sports participation to prevent unequal distributions by chance for these important prognostic factors. We further used a random permuted block size of three, assuring that every triplet of patients was distributed evenly over each treatment arm. The randomisation scheme was prepared before the start of the triall by an independent party and the assignment codes were kept in a safe vault in a sealed envelope, only to be opened after the short term data had been analysed.

After finishing the trial we checked the distribution and agreed that randomisation was successful. In a subsequent analysis we checked for work setting and work load. They were quite com-parable (see chapter 7). Fortunately, these factors were equally divided over the intervention groups. Furthermore, the randomisation procedure should have eliminated systematic differences in patients psychological characteristics

\section{Burnoris}

Most physiotherapy trials are inadequately blinded (see chapters 2 and 3 ). The common excuse is that it is impossible to blind physiotherapy manoeuvres. Of course, some interventions are hard or impossible to blind at the patient and therapist level (e.g., massage or exercise therapy). However, recently performed trials $s^{12-14}$ show that many physiotherapy interventions can effectively be blinded if one invests some time and ingenuity in the concept of blinding. Also blinding of the observer is easily achieved in almost all trials, unless the intervention leaves traceable marks on the patient.

In our trial we used a laser device that was blinded for both the patient and the therapist. The blinding procedure consisted of masking the optic properties of the laser beam and of manipulating the laser device. The patient and therapists both wore safety goggles with dark green glass in a clearly illuminated room. When the apparatus was turned on, it produced the same output on the screen irrespective whether the laser output was placebo, low or high dose laser. It additionally produced a soft whining noise during operation and an alarm sounded after completion of a 200 second treatment cycle. The $904 \mathrm{~nm}$ wavelength is invisible to the human eye.

As an extra precaution we randomised the three output levels over 21 settings on the laser apparatus, since in the unfortunate event 
of de-masking a treatment code the entire trial becomes unblinded when only one code for each arn of the trial exists. We further blinded the observers and the data analysils procedure, thus hoping to avoid biases on all foreseeable levels. After completion of the Individuals' treatment series we checked for success of blinding the patients. Our blinding procedure appeared to have been successful.

\section{Whinntrats}

A major threat to the validity of a trial is the amount of drop outs and losses to follow up. In the reviews we noted that some trials managed to loose over half of their participants. In our trial we monitored each patient carefully and used treatment calendars and small gifts to enhance compliance. All patients were present for baseline measurements. During the treatment period only 3 patients among 217 participants dropped out of the trial $(1.4 \%)$.

Long term measurements ( 3 months to 1 year follow up) were performed by telephone interviews. At one year follow-up we had lost $7.8 \%$ of the patients. In total 12 patients had moved to an uniknown address, 2 patients had their phones disconnected, one patient had no telephone, one patient had left an erratic phone number and one patient did not respond to either written or telephonic requests. All missing data were accounted for in an intention to treat analysis. There was no difference in outcome between the intentionto-treat analysis and the per protocol analysis. Therefore we think that the results of our trial are not biased by selective withdrawal rates.

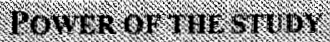

Sample size calculations are part of the design of each clinical trial and have practical and ethical consequences. ${ }^{\text {is }}$ A sufficient sample size also guards against biases inferred by unequal distribution of prognostic variables. At the onset of this project there was uncertainty about the efficacy of laser therapy in musculoskeletal disorders. Subsequent meta-analyses did not shed light on our research question. Therefore we formullated a hypothesis which aimed at researching the possible beneficial effect of laser therapy (see chapter 4). Although initially a one-sided cause-effect relationship was suspected, given the amount of uncertainty it was. deternined right from the start of the project that two-sided testing was called for. Our power calculations therefore demanded a sample size of at least 75 persons per group $(\alpha=0.05 /$ two-tailed; $1-\beta=80 \%)$ when we assume a difference of interest of at least $20 \%$. But we also felt that if we needed more than 75 persons per group, although statistically significant differences could occur, clinical relevant differences would not be of interest any more. To our surprise laser therapy performed worse than the placebo therapy, which justified our decision for twosided testing. As can be learned from the results, the outcome of power calculations varies per outcome measure. For instance, the difference in sick leave at one year would already have become significant with a sample size of 22 patients per group $(\alpha=0.05 /$ wo-tailed; $1-\beta=80 \%)$. The difference in pain after 28 days $(\alpha=0.05 /$ two. tailed; $1-\beta=80 \%$ ) however would need at least 97 patients per group to become significant. The achieved power in this trial was $67 \%$ for pain as a measure of outcome.

\section{P.r.6.1.}

One often worries about the homogeneity of a study population with respect to the maximal sensitivity to the intervention under 
study.

In this study we studied patients with sprained ankles. Patients with fractures were excluded. As is described in chapter 5 (selection of patients) we used strict entry criteria to assure a homogeneous study population with an optimal chance for responding to the interventions of the study.

We stratified successfully for severity of injury and sports participation. Also work load appeared to be equally distributed over the study groups.

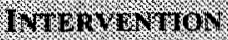

Preceding and during the conduct of our trial there was much debate on which dose is the most adequate when one applies laser therapy in musculoskeletal injuries. ${ }^{16,17}$ In our trial we compared a low dose laser with a high dose laser and a placebo laser treatment. To determine whether the claimed effects of LT were present we incorporated a placebo group, as new technologies are known to be surrounded by novelty effects, and thus have the potential of enhancing placebo responses. We were interested in the specific effects of laser therapy. The low dose represented a dose and intensity used in current physiotherapy practice. Since there are claims that this dose is too low to be effective, we also incorporated a high dose group in the trial. In this way we would be able to determine a dose-response relationship in case of cumulative effects, an inadequate doseresponse relationship in case of too low a dose, or perhaps a rebound effect in case of too high a dose. None of the above relations were found. Both laser groups performed worse than the placebo group. However, there seems to be an influence of laser on the irradiated tissue. The deceleration of the healing process in treated (laser) compared to non-treated (placebo) patients is remarkable.

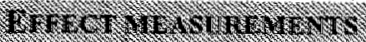

In our trial we used several outcome measures. Our primary measures of effect were pain and function, while our secondary outcome measures were subjective recovery, limitation in ADL, swelling, pain pressure testing, clinical evaluation, re-uptake of work and sports, satisfaction with the recovery rate and received treatment and the number of relapses. Pain was measured on a 11 point scale and very similar to the Dutch report mark system Numerical rating scales, with a range from $0-10$ points, provide reliable and consistent measures of clinical pain intensity when compared to VAS, both in acute as well as chronic pain measurements. ${ }^{18-20}$

Patients were allowed to take standardised pain medication in this trial. Pain medication was provided by us at intake and the use of it has been registered throughout the trial. It turned out that already two days after the intake almost everybody had stopped the use of medication. Moreover, the intake of pain medication during the first days was comparable between the groups. Since our primary measure of effect was measured at 5 days and onward, drug intake will probably not have influenced the outcome.

The other primary measure of effect, function, was measured on a 100 point scale, where 0 stands for no function and 100 for perfect function. Because a validated instrument for ankle function was lacking, we adapted the Lysholn scalle ${ }^{21}$ which was originally intended to measure knee function. It is described in more detail in chapters 4 and 5 , where the prognosis and the design of the trial are discussed. Although it has not been validated in the traditional sense, since there is no gold standard to compare with, we think that it has high face and content validity.

As for the other measures of outcome we opted for many, mostly validated measures of 
outcome. This is quite easy to do, both from a practical as well as a theoretical perspective and it assures detailed information about the trial, but also enhances the possibility of chance findings. We guarded against chance findings by blinding the analysis procedure, and having a team of blinded experts declare whether the observed effects were meaningful. Most measures of effect pointed in the same direction, and the power of the significant findings was high.

\section{Pensonutwiev}

One can wonder whether the trial as described in this thesis adds to the evidence. A lot of trials become more or less obsolete because of the time lapse between the initiation of the trial and the presentation of the final results. In this case it also took 4 years from the beginning to the end. Yet, when we look at the results of the $904 \mathrm{~nm}$ laser review, it is apparent that no one else has studied $904 \mathrm{~nm}$ laser therapy in ankle sprains before. Therefore the present study fills a gap in our knowledge. The outcome shows that laser therapy performs worse than placebo therapy and therewith reinforces our initial doubt whether $904 \mathrm{~nm}$ laser therapy would be effective in ankle sprains. Since the working mechanism of laser in musculoskeletal disorders such as tennis elbow, low back pain and strains and sprains in general is thought to be the same as in ankle sprains, we also suspect non-effectiveness of laser therapy in these disorders.

Recent research with $904 \mathrm{~nm}$ laser on tissue samples, using various dosages, has failed to show any effects on cell metabolism, and hence has not provided corroborative evidence. $^{12}$

However, it does not rule out the possibility that other wavelengths or other dosing regimens can deliver positive results.
The claim that laser therapy has no effect in biological tissues can be refuted. For, laser therapy does show capabilities of decelerating the healing process, and thus interferes with the metabolism of the tissue. Although a good model does not exist to clarify this mechanism, it could be possible that LT decelerates the inflammation process. Further in vivo and in vitro research is needed to shed light on this hypothesis and is being initiated right now.

\section{REFEREXEES}

1. Detsky AS, Naylor CD, Rourke $\mathrm{K}_{*}$ McGeer AJ, $L^{\prime} A b b e \mathrm{KA}$. Incorporating variations in the quality of individual randomized controlled trials into meta-analysis. J Clin Epid 1992; 45: 255-65.

2. Bie RA de. Methodology of systematic reviews: an introduction. Phys Ther Rev 1996; 1: 47-51.

3. Vet HCW de, Bie RA de, Heijden GJMG van der, Verhagen AP, Sijpkes $P$, Knipschild PG. Systematic reviews on the basis of methodological criteria. Physiotherapy 1997; 83: 284-9.

4. Riet $\mathrm{G}$ ter, Kleijnen J, Knipschild P. Acupuncture and chronic pain. A criteria based meta-analysis. J Clin Epid 1990; 43: 1191-9.

5. Koes BW, Bouter LM, Heijden GIMG wan der, Knipschild PG. Physiotherapy exercises and back pain. BMJ 1991; 302: 1572-6.

6. Heijden GJMG wan der, Beurskens AJHM, Koes BW, Assendelft WJ, Vet HCW de, Bouter LM. Traction for back and neck pain: a blinded review. Physical Therapy 1995; 75: 93-104.

7. Pocock SJ. Clinical Trials: A practical approach. Chichester: John Wiley \& Sons, 1991.

8. Schulz KF, Chalmers I, Hayes RJ, Altman DG. Empirical evidence of bias: dimensions of methodological quality associated with estimates of treatment effects in controlled trials. JAMA $1995: 273 ; 408-12$.

9. Cochrane Collaboration Handbook, April 1997. http:/hiru momaster.ca/cochrane/handbook/ default.htm.

10. Rosenthal R Parametric measures of effect size. In: The handbook of research synthesis. Eds. Cooper H, Hedges LV. Russel Sage Foundation, New York, 1994.

11. Meinert CL. Clinical trials; design, conduct and 
analysis. Oxford University Press, New York, 1986.

12. Beurskens $A J$, Vet $H C$ de, Köke AJ et al. Efficacy of traction for non-specific low back pain: a randomised clinical trial. The Lancet 1995; 340: $195-60$.

13. Heijden GNMG van der. Shoulder disorder treatment; efficacy of ultrasound therapy and electrotherapy. PhD Thesis, Maastricht University, 1996.

14. Riet $G$ ter, Kessels $A G H$, Knipschild P. Randomised clinical trial of ultrasound treatment for pressure ulcers. BMJ 1995; 310: 1040-1.

15. Knottnenus JA, Gezondheidszorgonderzoek in extramurale settings. Ethiek en recht in de gezondheidszorg. 1997; 151-98.
16. Kitchen SS, Partridge Cl. A review of low level laser therapy. Physioterapy 1991 ; 77: 161-8.

17. Breugel $H$. van. Janus Jongbloed Research Centrum, Rijksuniversiteit Utrecht, 1993.

18. Price DD, Bush FM, Long S et al. A conparison of pain measurement characteristics of mechanical visual analogue and simple numerical scales. Pain 1994; 56: 217-26.

19. Jensen MP, Turner JA, Romano M. What is the maximum number of lewels meeded in pain intensity measurement? Pain 1994; 58: 387-92.

20. Revill SI, Robinson JO, Rosen M et al. The reliability of a linear visual analogue scale for evaluating pain. Anaesthesia, 1976; 31: 1191-8.

21. Lysholm J, Gillquist J. Evaluation of knee ligament surgery results with special emphasis on use of a scoring scale. American Journal of Sports Medicine 1982; 10:150-4.

22 Bouma MG, Buurman WA, Wildenberg FAJM van den. Low energy laser irradiation fails to modulate the inflammatory function of juman monocytes and endothelial cells. Lasers in Surgery and Medicine 1996; 19 (2): 207-15. 
Chapter 1 provides an introduction to this thesis by posing questions about effective therapies and prognosis that every patient likes to ask when spraining an ankle. Additionally, the thesis gives answers on the research question concerning the efficacy of laser therapy, which is advocated as a successful means in the treatment of acute lateral ankle sprains.

CHAPTER 2 reports on a systematic review that summarises the efficacy of conservative interventions in acute lateral ankle sprains. By means of computer aided searches of databases and of bibliographic indexes we retrieved trials on the efficacy of conservative interventions in acute lateral ankle sprains. Furthermore, we checked congress reports, reviews and relevant citations. Subsequently, all retrieved studies were scored on these methodological quality. Effect sizes were calculated for days of sick leave, pain and swelling.

We investigated the effects of physiotherapy interventions versus other interventions or placebo interventions, in subjects with acute lateral ankle sprains. Of all studies, 44 fulfilled our entry criteria. Study quality ranged from poor ( 9 points) to rather good (70 points), of which only two studies scored more than 60 points. Both studies (on pulsed shortwave therapy) showed no effect. Tape was found to be superior over other types of treatment, in effect shortening the duration of sick leave, while plaster of Paris treatment seemed to prolong sick leave.

Chapter 3 presents a systematic review on the efficacy of $904 \mathrm{~nm}$ low level laser therapy (LT) in musculoskeletal disorders.

In order to retrieve randomised trials computer aided searches of databases and of bibliographic indexes were performed. Furthermore, congress reports, reviews and handbooks were all checked for relevant citations. Subsequently, all retrieved studies were scored on methodological quality.

We looked especially at the effects of 904 nm LT versus placebo or any other intervention, in subjects with a condition for which LT was thought a feasible intervention. Of all studies, 21 fulfilled our entry criteria, and were assessed in a blinded manner on methodological criteria. Overall, study quality ranged from poor to reasonable. No convincing evidence was found for the efficacy of LT, except perhaps for knee problems and myofascial pain, where the results were inconsistent. We conclude that $904 \mathrm{~nm} \mathrm{LT}$ has not yet proven to be effective in the treatment of musculoskeletal disorders, but that further and improved research is needed to shed more light on its efficacy.

Chapter 4 shows the development of a diagnostic tool for predicting the severity of ankle sprains just after injury. Since data obtained by diagnostic imaging techniques are still imperfect, we decided to use data from history taking, and signs and symptoms that are part of the intake routine. During a three month period data were collected on 35 patients with lateral ankle sprains who visited the Accident and Emergency department of the University Hospital of Maastricht. Assessments took place at intake and at two and four weeks after injury. Dependent variables were "healed ankle after two and four weeks." Predicting wariables were the data obtained at intake by the physician, the 
physiotherapist and the patient. The ability to predict outcome after two and four weeks was determined in a bivariate logistic analysis, followed by multivariate logistic modelling.

Accurate prediction of recovery time at intake appeared to be possible. Best two weeks predictor was the modified function score, with which an accuracy of $97 \%$ was achieved. Four weeks prediction was most accurate when function score was used together with the report mark from the doctor and the palpation score (accuracy of $81 \%$ ).

Since it was a pilot study, a larger study is called for to confirm these results.

Chapters 5 to 7 report on the design, the short term and the long term results of a randomised clinical trial of the efficacy of LT on lateral ankle sprains. 217 Patients with acute lateral ankle sprains were randomised into three groups and received high or low dose or placebo laser therapy as an addition to a standardised treatment regimen, which consisted of four weeks of brace therapy, together with standardised home exercises. Twelve treatments in four weeks were given. Short term assessment took place every treatment day, followed by long term measurements at $3,6,9$, and 12 months. Patients, therapists, assessors and analysts were blinded for the assigned treatment. Intention to treat analysis of the short term results showed no significant difference on the primary outcome measure pain, although the placebo group was slightly in favour. The placebo group performed significantly better on the other primary outcome and function measure days of sick leave, and at some points in time for hindrance in activities in daily life and pressure pain, as well as subjective recovery.

Long term analyses showed that total days of absenteeism from work and sports were remarkably lower in the placebo group when compared to the laser groups: on average 4.5 (work) and 7 (sports) days. The total number of relapses in the low dose laser group was much higher than in the other two groups.

We conclude that laser therapy in ankle sprains is not an effective therapy. On the short term it fails to alleviate pain or to speed up ADL recovery. On the long term it does not reduce absenteeism from work or sports, nor does it prevent relapses.

Chapter 8 presents a general discussion on various aspects of the research of in this thesis. The chapter is divided in four parts. The first part evaluates the value and outcomes of the systematic reviews, while the second part addresses the prognostic study. In the third part the clinical trial is discussed. Special attention is paid to factors influencing internal and external validity. The discussion concludes with a personal view on the efficacy of laser therapy. 


\section{NEDERLANIDSE SAMENVATTING}

Dit proefschrift is geschreven in het Engeis, en meestal in een taalgebruik dat voor de niet vakinhoudelijk geschoolde lezer moeilijk te doorgronden is. Vandaar deze uitgebreide samenvatting in het Nederlands voor diegenen die meer willen weten omtrent de effectiviteit van (laag vermogen) lasertherapie bij laterale enkelbandletsels (verstuikte enkels). In het eerste deel worden in het kort de twee literatuuroverzichten uit dit proefschrift besproken. Het tweede deel behandelt onderzoek naar het klinisch verloop van enkelbandletsels en het ontwikkelen van voorspellingsmodellen. In het derde deel worden de achtergrond van het eigen onderzoek, alsmede de opzet, resultaten, discussie en de conclusies beschreven.

\section{DEDL 1}

\section{Mert-Matirses}

In het kader van dit proefschrift zijn twee systematische literatuuroverzichten geschreven. Eén gaat over de effectiviteit van $904 \mathrm{~nm}$ laag vermogen lasertherapie bij aandoeningen van het bewegingsapparaat, terwijl de andere gaat over conservatieve therapieën die gebruikt worden ter behandeling van patiënten met een enkelbandletsel.

Het gaat te ver om in deze samenvatting de gehele methode van literatuuronderzoek uit te leggen, maar toch wil ik u een korte samenvatting van beide literatuuroverzichten niet onthouden.

\section{CONSERV T TIETE THER TPLEET}

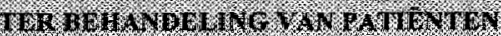

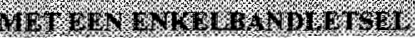

Met behulp van de geautomatiseerde literatuurbestanden MEDLINE en EMBASE zijn.

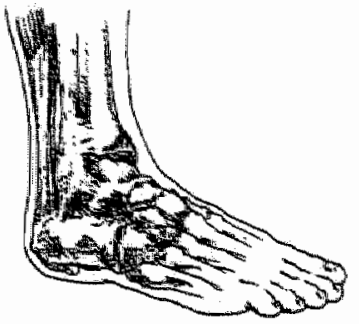

studies opgespoord die conservatieve (nietoperatieve) behandelingen bij laterale enkelbandletsels bestudeerden. Daarnaast is de Cochrane Database voor Randomised Trials en de database van het Rehabilitation and Related Therapies Field geraadpleegd. Van alle gevonden artikelen zijn de referenties nagelopen en tevens zijn congresverslagen, literatuuroverzichten en handboeken geraadpleegd. In totaal zijn 81 studies opgespoord, waarvan er uiteindelijk 44 aan de inclusiecriteria voldeden. Deze 44 studies werden vervolgens op methodologische kwaliteit beoordeeld en effect-sizes (gestandaarde verschillen in effect tussen de bestudeerde interventies) werden berekend voor ziekteverzuim, pijn en zwelling. Opvallend was het grote aantal verschillende behandelwijzen dat werd bestudeerd.

De methodologische kwaliteit op een 100 punts-schaal varieerde van slecht ( 9 punten) tot goed (70 punten). Slechts twee studies scoorden meer dan 60 punten.

Tabel 1 laat de effecten zien zoals deze te berekenen waren voor de uitkomstmaten ziekteverzuim, pijn en zwelling.

Wanneer we kijken naar dagen ziekteverzuim dan lijkt taping of bandage de beste (meest economische) therapievorm, terwijl gips het slechtst presteert. Op de andere effectmaten is het moeilijker een oordeel te geven daar er weinig gegevens bekend zijn. 
Tabel 1 . Effect van behandelingen bij acute enkelbandletsels

\begin{tabular}{|c|c|c|}
\hline 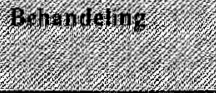 & moth & $f_{1}$ \\
\hline 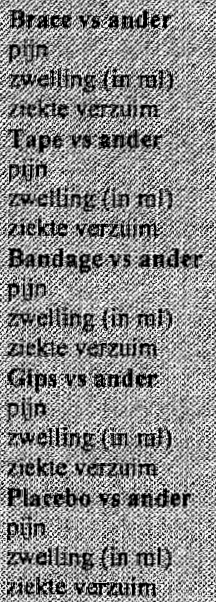 & 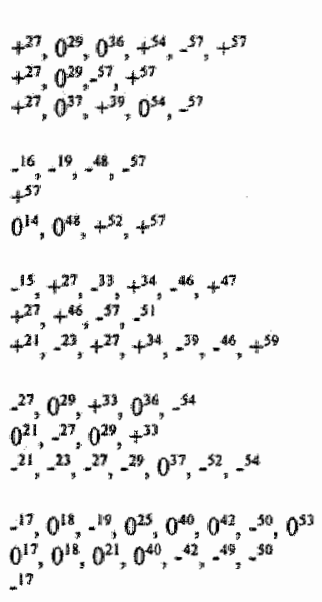 & $\begin{array}{l}\text { pijn wermindering } \\
\text { reductie: } \\
\text { onbeslist } \\
\text { geen pinn vermindering } \\
\text { reductie } \\
\text { reductie } \\
\text { onbeslist } \\
\text { oribeslist } \\
\text { onbeslist } \\
\text { onbeslist } \\
\text { onbestist } \\
\text { toename } \\
\text { geen pijn vermindering } \\
\text { geen reductie } \\
\text { geen reductie }\end{array}$ \\
\hline
\end{tabular}

+ reductie wergeleken met andere behandeling(en):

0 geen verschil

- toemame

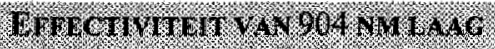

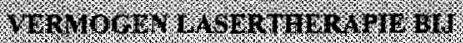

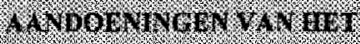

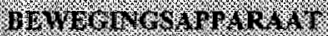

Ook voor dit literatuuroverzicht zijn met behulp van de geautomatiseerde literatuurbestanden MEDLINE en EMBASE alle gerandomiseerde effectonderzoken op gebied van $904 \mathrm{~nm}$ laser therapie opgespoord die gedurende de periode 1966 tot 1996 waren verschenen. Van alle gevonden artikelen zijn de referenties nagelopen en tevens zijn congresverslagen, literatuuroverzichten en handboeken geraadpleegd.

In totall werden 25 studies gevonden die het effect van $904 \mathrm{~nm}$ laser therapie onderzochten en waarin deze therapie gecontrasteerd werd met een placebobehandeling of een andere behandeling. Hiervan voldeden er 21 aan onze inclusiecriteria; deze werden vervolgens op hun methodologische kwaliteit beoordeeld. Drie studies rapporteerden het effect van laser (LT) bij patiënten met reuma; twee studies vonden geen effect. Eén studie rapporteerde positieve bevindingen. Deze waren echter gebaseerd op een voor-na vergelijking; tussen de groepen waren er geen verschillen. Twee van de drie studies bij patiënten met aangezichtspijn wonden positieve resultaten.

Drie van de vier studies die knie aandoeningen bestudeerden vonden positieve trends; de resultaten van éen van deze studies waren achter gebaseerd op een voor-na vergelijking; tussen de groepen waren er geen verschillen. Slechts één studie naar het effect van laserbehandeling bij trigger points en liet positieve resultaten zien.

Drie studies onderzochten de effectiviteit van LT bij patiënten met decubitus. Alhoewel alle 


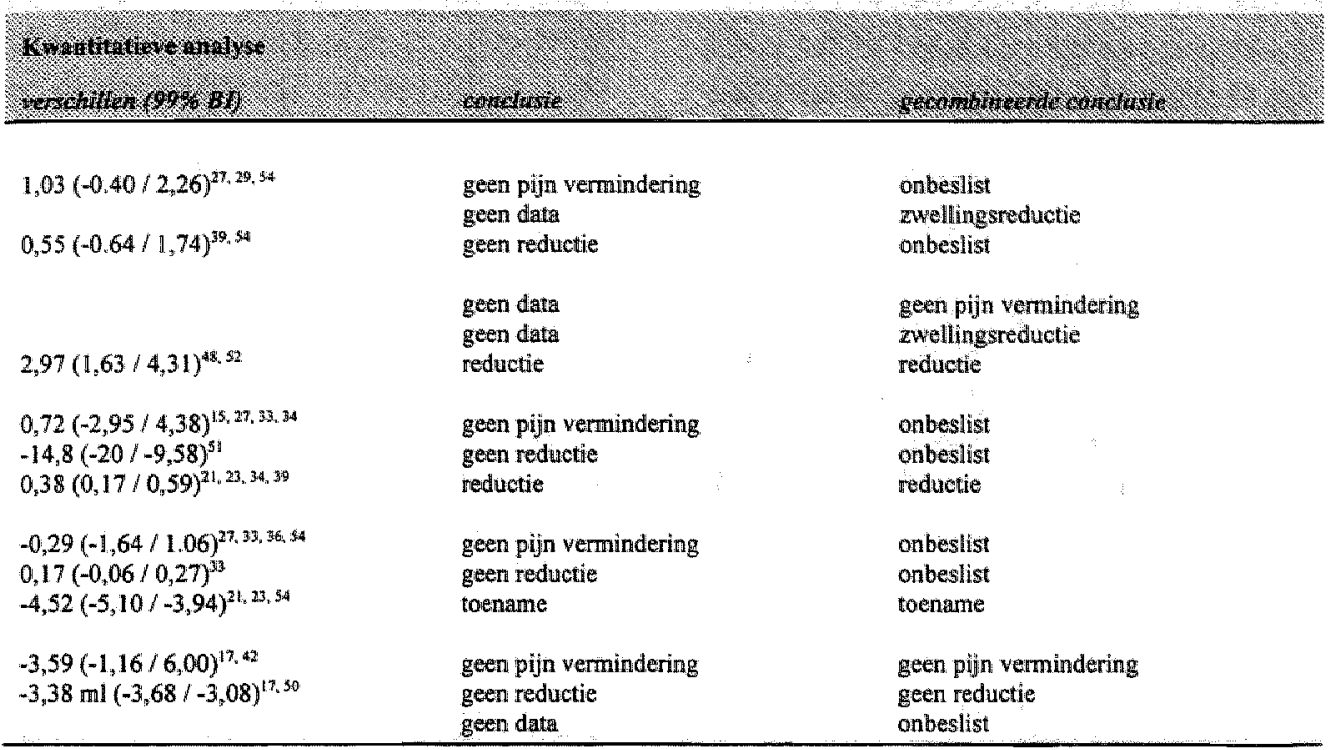

drie positieve resultaten lieten zien zijn er ernstige fouten in de opzet en uitvoering van het onderzoek gemaakt.

Vier studies bestudeerden patiënten met een tenniselleboog; deze waren alle negatief. Eén studie onderzocht tendinitis en liet positieve resultaten zien. Tenslotte bestudeerden 2 onderzoeken het effect van LT bij lage rug klachten. Bij beide waren er echter methodologische problemen in opzet en uitvoering van het onderzoek.

Tabel 2 laat samengevat nog eens de resultaten zien.

Samenvattend kunnen we zeggen dat de methodologische kwaliteit varieerde van slecht tot redelijk. Slechts op het gebied van knie aandoeningen en aangezichtspijn lijken er voorzichtige aanwijzingen te zijn die duiden op effectiviteit van lasertherapie.

Tabel 2: Effect van $904 \mathrm{NM}$ laser therapie bij aandoeningen van het bewegingsapparaat

\begin{tabular}{|c|c|c|}
\hline ( & 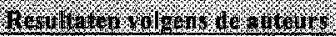 & ays \\
\hline reuma $(n-3)$ & $+21,-2 \pi,-3 i$ & ，它, \\
\hline aangerichispin $(\mathrm{n}-3)$ & $+23,+26 y=3$ & 40,490 \\
\hline krie andotaingen $(n-4)$ & $+^{33},+34,+34,-24$ & 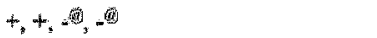 \\
\hline triger pouns $(n-n)$ ? & +4 & : \\
\hline decubitis $(n=3)$, & $++^{32},+^{34}, t^{32}$ & $-4+4$ \\
\hline tenn $s$ elleboog $(n-4)$ & $-33 y, n^{339},-40,-4$ & $-_{H} m_{B} m_{g}$ \\
\hline tendinits $(n-1)$ & +3 & +6 \\
\hline lage rutg klachien $\left(n_{2}\right)$ ) & $+x^{30}$ & -10 \\
\hline
\end{tabular}

Voor- na vergelijken zijn herberekend als tussengroeps vergelijking. Nummers in superscript verwifzen thaar de studies (terug te vinden in hoofstuk 6 van dit proefschrift), terwili $:=$ niet effectief $+=$ effectief en ? $=$ on beslist.

studies met een methodologische score lager dan 40 punten (uit maximal 100 ) 


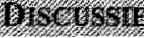

Beide systematische reviews in dit proefschrift maken gebruik van dezelfde criteriumlijst om de interne validiteit, de precisie en de relevantie van de onderzochte studies te meten. Alhoewel de lijst is gebaseerd op algemeen geaccepteerde principes van klinisch wetenschappelijk onderzoek, blijft het moeilijk om de kwaliteit van de onderzoeken adequaat in te schatten. Dit komt mede door dat veel studies weinig informatie bevatten, of omdat een aantal voor de hand liggende middelen om de kwaliteit van de studies te verbeteren niet zijn toegepast.

Het meest opvailend is het gebrek aan blindering. Zeker op nivo van effectmeting en analyse is dit goed mogelijk. Daarnaast had in een aantal studies ook op patiënt- en behandelaarsnivo geblindeerd kunnen worden.

Adequate beschrijving van uitvallers, prognostische vergelijkbaarheid van de patiekntengroepen en beschrijving van neveneffecten en nevenbehandelingen ontbreekt eveneens in vele gevallen. Interpretatie van de gegevens wordt hierdoor ernstig bemoeilijkt.

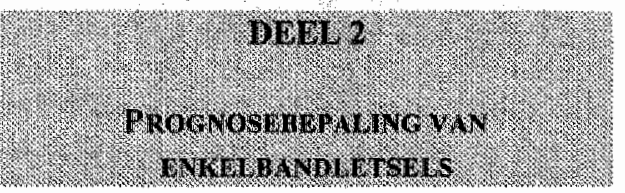

Om een goede behandeling van enkelbandletsels te kunnen garanderen is een goede inschatting van de ernst van het letsel en de prognose van het te verwachten herstel belangrijk. Zoeis al uit de inleiding in deel 1 bleek, is het moeilijk de ernst van het letsel goed vast te stellen, mede omdat harde diagnostische criteria antbreken of onbetrouw baar zijn.
We hebben geprobeerd om met behulp van anamnestische gegevens en eenvoudig lichamelijk onderzoek lichte van ernstige letsels te kunnen onderscheiden op basis van de prognose.

\section{Merirone}

35 patiënten die zich bij de eerste hulp afdeling van het academisch ziekenhuis Maastricht (azM) meldden met een acuut lateraal enkelbandletsel zijn anamnestisch en lichamelijk uitgebreid onderzocht.

De bevindingen van de dienstdoende arts, de fysiotherapeut en de patiënt zelf werden systematisch verzameld. Daarbij waren de arts en de fysiotherapeut geblindeerd voor elkaars waarnemingen.

$\mathrm{Na}$ de intake kregen alle patiënten de standaard behandeling, bestaande uit 5 dagen een drukverband en daarna een Coumans bandage gedurende maximaal zes weken.

Omdat de patiënten iedere twee weken terugkeren voor het verwisselen van de Coumans bandage zijn zij op 2 en 4 weken na het trauma opnieuw door ons onderzocht.

Bij de uiteindelijke analyse zijn herstel na twee en vier weken als afhankelijke variabele meegenomen en als voorspellende variabelen alle data die verzameld zijn uit de anamnese en het lichamelijk onderzoek bij de intake. Met behulp van een bivariaat model zijn de uitkomsten op 2 en 4 weken bepaald. Om als beter (hersteld) te kunnen worden aangemerkt, diende de patiënt zelfstandig te zijn wat betreft de activiteiten van het dagelijkse leven (dit komt overeen met een functiescore van meer dan 76 punten), en op minder dan twee van de twaalf vooraf gedefinieerde punten op de enkel pijn aan te geven. 


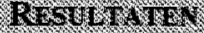

In tabel 3 staan de uitkomsten met betrekking tot de twee en vier weken voorspellingen gerelateerd aan de data zoals die verzameld zijn tijdens de intake.
Tabel 3 dient als volgt geinterpreteerd te worden: van de patienten die nog ziek zijn na twee weken had $93 \%$ spontane pijn aan de enkel bij intake, vergeleken met $75 \%$ spontane pijn bij de patiènten die na twee weken. beter waren.

Tabel 3: Twee en vier weken voorspellingen in relatie tot bevindingen uit anamnese en lichamelijk onderzoek bij intake

\begin{tabular}{|c|c|c|c|c|}
\hline & 2 & watinter & 4.6kin & Wht \\
\hline Maritalen & $21 /(1)=21$ & $0+(2)=1,1)$ & 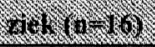 & $0+1+1,(1,5)$ \\
\hline spontane pijn & $93 \%$ & $75 \%$ & $93 \%$ & $80 \%$ \\
\hline Kissing pun & $55 \%$ & $25 \%$ & $50 \%$ & $47 \%$ \\
\hline Instabiliteit enstig & $15 \%$ & $0 \%$ & $21 \%$ & $7 \%$ \\
\hline matig & $54 \%$ & $50 \%$ & $71 \%$ & $43 \%$ \\
\hline 10. - geen. & $31 \%$ & $50 \%$ & $7 \%$ & $\$ 0 \%$ \\
\hline gevil ht nemen op aangedarie voet onmogelijk & $65 \%$ & $0 \%$ & $56 \%$ & $47 \%$ \\
\hline Awelling & $96 \%$ & $75 \%$ & $100 \%$ & $93 \%$ \\
\hline slecht looppatroon & $100 \%$ & $75 \%$ & $100 \%$ & $93 \%$ \\
\hline finctie score $s 35$. & $97 \%$ & $0 \%$ & $94 \%$ & $73 \%$ \\
\hline slecht functie enikel & $62 \%$ & $50 \%$ & $71 \%$ & $50 \%$ \\
\hline 22 pijppunten & $66 \%$ & $25 \%$ & $64 \%$ & $47 \%$ \\
\hline recidief & $27 \%$ & $25 \%$ & $13 \%$ & $47 \%$ \\
\hline enstletsel (rapport clffer 25$)$ & $76 \%$ & $25 \%$ & $88 \%$ & $60 \%$ \\
\hline Miet beter in 2 weken & $88 \%$ & $50 \%$ & $93 \%$ & $79 \%$ \\
\hline met beter in 4 wehen & $8 \%$ & $25 \%$ & $0 \%$ & $14 \%$ \\
\hline miet aan het werk in 7 dagen & $15 \%$ & $0 \%$ & $29 \%$ & $0 \%$ \\
\hline niet aan hiet sporten in 2 weken & $55 \%$ & $33 \%$ & $60 \%$ & $33 \%$ \\
\hline
\end{tabular}

- De functie score is een 100 punten schaal die pijn, zwelling, instabiliteït, gewicht nemen op de aangedane woet en looppatroon combineert.

In tabel 4 wordt de functie score uitgezet tegen de gouden standaard "beter of ziek".

Uit onze data bleek dat een bij een afkappunt wan 35 punten op de functieschaal het kleinste aantal patienten verkeerd werd geclassificeerd.

Tabe: 4: Twee weken voorspelling op genezing met behulp van de functie score

\begin{tabular}{|c|c|c|c|c|}
\hline & & \multicolumn{2}{|c|}{ (1) } & \\
\hline & & ziek & - beter & \\
\hline \multirow{2}{*}{ 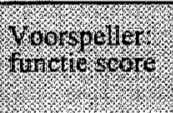 } & ziek ( $\leq 35$ punten) & 28 & 0 & + Pred val $100 \%$ \\
\hline & bieter $(>35$ punten) & 1 & 4 & - Pred val 80\% \\
\hline & & Sens 97\% & Spec 100\% & \\
\hline
\end{tabular}


Genezing na vier weken werd het best voorspeld door een combinatie van het rapportcijfer voor emst van het letsel, samen met de functie score en de pijnpunten score (zie Tabel 5). Toch wordt in dit model bij 6 van de 31 patiènten een foute voorspelling gemaakt.

Tabel 5: Vier weken voorspelling op genezing door een combinatie van rapport cijfer ernst, functie score en pijnpunten score

\begin{tabular}{|c|c|c|c|c|}
\hline \multirow[t]{2}{*}{ : } & & \multicolumn{2}{|c|}{ 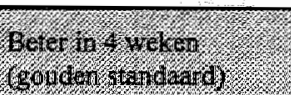 } & \\
\hline & & ziek & beter & \\
\hline \multirow{2}{*}{ 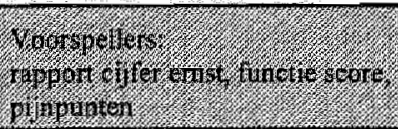 } & ziek & 13 & 3 & + Pred val $81 \%$ \\
\hline & beter & 3 & 12 & - Pred val $80 \%$ \\
\hline & & Sens $81 \%$ & Spec $80 \%$ & \\
\hline
\end{tabular}

\section{5c18sin:}

Met dit onderzoek hebben we geprobeerd een diagnostisch probleem op te lossen door de prognose van het herstel na enkelbandletsel te bestuderen. Sommige variabelen in dit onderzoek bleken nauwelijks gevoelig voor verandering, bijvoorbeeld leeftijd, maar zijn vaak uitstekende voorspellers voor prognose. Andere variabelen, zoals pijn, zijn weliswaar zeer gevoelig voor verandering, maar zijn juist slechte prognostische factoren. Immers, iedereen heeft pijn na een inversietrauma, en dus kan pijn slecht discrimineren tussen lichte en zwatere letsels.

Uit het onderzoek blijkt dat het tamelijk goed mogelijk is een voorspellend model te ontwikkelen omtrent de korte termijn genezing van enkelbandletsels met behulp van een eenvoudige schaal: de functie score. Als vuistregel kan hieruit worden afgeleid dat indien de pa-tient wandelend binnenkomt, hij of zij een grote kans heeft dat het een licht letsel is en binnen twee weken genezen. Zwelling en pijn zijn slechte voorspellers voor herstel.

\section{DrFU 3}

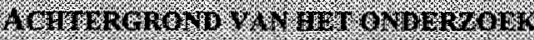

In Nederland zijn bijna 5 miljoen sporters actief, waarvan er meer dan de helft jaarlijks een letsel of blessure oplopen tijdens de sportbeoefening. Hiervan worden er 1,2 miljoen jaarlijks medisch behandeld. Een kwart van deze letsels betreft het kapselbandapparaat van de enkel. Nog afgezien van de medische kosten die dit met zich meebrengt, zijn ook de kosten in verband met ziekteverzuim alsmede tijdelijke of blijvende arbeidson- geschiktheid aanzienlijk. Circa $20 \%$ van alle geblesseerden inzake enkelbandletsels kent als gevolg hiervan een arbeids- of schoolverzuim van 7,3 dagen, en zorgt voor zo'n $10-15 \%$ van alle werkverzuim in Nederland.

Ten aanzien van de behandeling van laterale enkelbandletsels bestaat er in de literatuur geen uniformiteit. Dit wordt ten dele veroorzaakt door de gebrekkige diagnostiek. Laterale enkelbandletsels laten zich met de huidige mogelijkheden in de beeldvormende diagnos-tiek (röntgen) moeilijk vaststellen. Ook met andere beeldvormende 
diagnostische technieken, zoals echografie, CT-scan is de aanwezigheid en ernst van het letsel niet goed te bepalen. Daarnaast blijkt dat, omdat de behandelresultaten van operatie of bandagetherapie, één jaar na letsel vergelijkbaar zijn en omdat in feite alle laterale enkelbandletsels zich lenen voor bandagetherapie de ernst van het letsel niet of nauwelijks van invloed is op het herstel op lange termijn.

Herstel van de functie op de korte termijn (weken) wordt behalve door mogelijke instabiliteit mede bepaald door de mate van zwelling rondom het enkelgewricht. Deze zwelling wordt veroorzaakt door hematoomen oedeemvorming rondom het verscheurde kapselbandapparaat. De zwelling kan worden tegengegaan door middel van ijs, drukverbanden, rust en elevatie in de eerste uren na letsel.

In de literatuur wordt (laag vermogen) laser therapie in een aantal publikaties vermeld als een effectieve aanvullende therapievorm bij de behandeling van weke delen letsels. In een aantal gerandomiseerde effectonderzoeken is een versnelde pijnvermindering en een sneller functioneel herstel gerapporteerd. Alhoewel het hier gerandomiseerde onderzoeken betreft, was de onderzoeksmethode niet optimaal en zijn er tevens vragen over de toegepaste dosering van lasertherapie, zowel in vaststelling van de gehanteerde dosis als in het gebruik van de optimale dosis. Toch wordt lasertherapie in de dagelijkse (sport- en fysiotherapeutische) praktijk veel gebruikt ter behandeling van laterale enkelbandletsels.

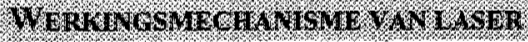

Er zijn twee theorieẽn die het werkingsmechanisme van lasertherapie proberen te verklaren. Eén theorie stelt dat in het geval van een letsel of trauma de weefseltoestand verandert, waar-door de elektromagnetische communicatie tussen cellen verslechtert. Lasertherapie zou deze disbalans kunnen herstellen. De andere theorie stelt dat laserlicht aangrijpt op membraaneiwitten van de cel en zodoende de stofwisseling in de cel belinvloedt. De biologische effecten die aan laser worden toegeschreven zijn: pijndemping, ontstekingsremming en herstel van bot-, spier-en bindweefsel.

Ten aanzien van de gebruikte doseringen bestaat er geen overeenstemming. Het is vooralsnog onduidelijk met welke dosering en met welke golflengte laag vermogen lasers het meest effectief zijn. Laag vermogen lasers zijn in tegenstelling tot chirurgische lasers, bij applicatie via de huid onschadelijk en laten een grote variatie in doseringen toe. Een bovengrens in de dosering voor softlaser therapie wordt pas gevonden vanaf 450 $\mathrm{J} / \mathrm{cm}^{2}$; dan treden weefseleffecten in de vorm van oedeem en eerstegraads verbranding op. Ten tijde van het begin van het onderzoek (1993) onderscheidde men binnen de softlaser therapie twee dosimetrische opvattingen; de opvatting dat er laag gedoseerd dient te worden versus de opvatting dat er hoog gedoseerd dient te worden. Lage doseringen bevinden zich voor softlaser tussen 0,01 en $0,5 \mathrm{~J} / \mathrm{cm}^{2}$ terwijl hoge doseringen zich tussen 0,5 en $5 \mathrm{~J} / \mathrm{cm}^{2}$ bevinden.

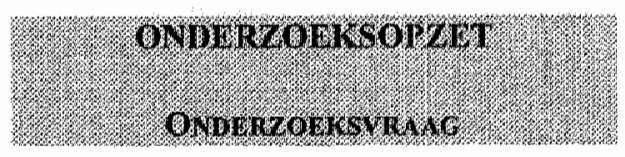

Uit het bovenstaande kunnen twee vraagstellingen worden gedestilleerd.

Wat is de toegevoegde waarde van lasertherapie als aanvulling op de gebruikelijke functionele behandeling van 
laterale enkelbandletsels, en welke dosering is het meest effectief?

Bij de beantwoording van deze onderzoeksvragen wordt gelet op zowel korte als lange termijn effecten. Voor de korte termijn zijn pijn-en zwellingswermindering alsmede funktieherstel wan belang, terwijl op de middellange en lange termijn werk-en sporthervatting en het verminderen van het aantal recidieven (herletsels) op de voorgrond staan.

\section{0.}

In dit onderzoek hebben we het effect van lasertherapie in twee doseringen vergeleken met een placebo laserbehandeling door middel van een geblindeerd en gerandomiseerd experiment, waarbij de laserbehandelingen als extra therapie gegeven worden op een gestandaardiseerde en geaccepteerde behandeling.

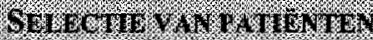

In dit onderzoek zijn in totaal 217 patiènten over 3 groepen gerandomiseerd, waarbij er voor gezorgd is dat in alle drie de groepen evenveel personen met een licht of ernstig letsel zitten, terwijl ook het aantal sporters per onderzoeksgroep vergelijkbaar is. Alle patienten mogen aan het onderzoek meedoen indien zij zich binnen 48 uru na trauma op de eerste hulp melden met een lateraal enkelbandletsel, tussen de 18 en 65 jaar oud zijn en het informed consent ondertekenen.

Patienten die in het voorafgaande jaar al eerder een lateraal enkelbandletsel hebben gehad of die al eens aan de enkel zijn geopereerd worden voor het onderzoek uitgesloten. Ook patiènten met fracturen, open wonden of afwijkingen aan de onderste ledemaat of voet worden uitgesloten. Patienten met congenitale afwijkingen, systeemziekten en verstandelijke handicap alsmede personen die de Nederland- se taall niet machtig zijn worden eveneens uitgesloten. Ook patienten die gedurende de behandelperiode van het onderzoek van plan zijn op vakantie te gaan, of buiten de regio te gaan wonen c.q. werken worden van deelname uitgesloten.

Patiënten die geschikt zijn om mee te doen krijgen een gedetailleerde beschrijwing van het onderzoek, waarin ook staat dat men door het lot aan een behandelgroep werd toegewezen. Na deze intake procedure door de arts op de eerste hulp, worden zij de volgende ochtend op de afdeling fysiotherapie verwacht voor de eerste behandeling en meting.

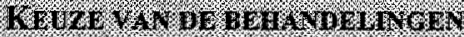

In ieder onderzoek streeft men naar een voldoende groot contrast tussen de diverse onderzochte groepen om klinisch relevante verschillen te kunnen ontdekken. In dit onderzoek is uitgegaan van een standaard behandeling bij enkelbandletsels, waarbij de lasertherapie als extra moest dienen. Om een zuivere schatting van het effect van lasertherapie te krijgen is éen groep behandeld met een placebo-laser, terwijl beide andere groepen echte laserbehandelingen krijgen, maar met verschillende doseringen. In de onderstaande paragrafen worden de keuzen voor de behandelingen uitgelegd.

Aangezien er in de literatuur geen duidelijkheid bestaat over de juiste dosering of intensiteit hebben we gekozen voor drie doses, namelijk hoog $\left(5 \mathrm{~J} / \mathrm{cm}^{2}\right)$, laag $\left(0,5 \mathrm{~J} / \mathrm{cm}^{2}\right)$ en placebo $\left(0 \mathrm{~J} / \mathrm{cm}^{2}\right)$, waarbij de intensiteit in het weefsel op respectievelijk $0.7,0.07$ en 0 Joule per $\mathrm{cm}^{2}$ ligt.

De standaardbehandeling die iedere deelnemer krijgt bestaat uit vier dagen een drukverband met vette watten gevolgd door $31 / 2$ week een Push brace. Patienten krijgen tevens ge- 
standaardiseerde huiswerkoefeningen en informatie over het te verwachten herstel.

De laserbehandeling is in de drie groepen gelijk, met uitzondering van de dosis. De meest pijnlijke plek aan de buitenkant van de enkel (door de patiènt en therapeut bepaald) wordt met de laser gedurende 200 seconden behandeld. Hierbij wordt de te bestralen plek eerst met alcohol schoongemaakt. Alle groepen volgen hetzelfde behandelschema. In de eerste week krijgt men 5 behandelingen, in de tweede week 3 en in week drie en vier telkens 2 behandelingen per week. Zowel de patiënt als de therapeut zijn geblindeerd voor de behandeling; dat wil zeggen dat ze geen idee hebben in welke behandelgroep de patiënt zit. $\mathrm{Na}$ afloop van de behandeling wordt de voet steeds weer ingezwachteld of weer voorzien van de brace.

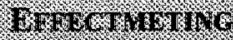

In dit onderzoek hebben we gekozen voor effectmaten die de vanuit het perspectief van de patiënt de klacht het beste weergeven. Gekozen zijn voor de mate van pijn als een rapportcijfer ( 0 tot 10$)$ en een functiescore (van 0 tot 100). De functiescore is een 100 punten schal die pijn, zwelling, instabiliteit, gewicht op de aangedane voet nemen en looppatroon combineert. Als secundaire effectmaten is gekozen voor het aantal dagen werk- en sportverzuim, functioneren in activiteiten van het dagelijks leven (ADL), drukpijn, enkelzwelling, recidieven, subjectief ervaren herstel en tevredenheid over de behandeling en herstel.

Er wordt gedurende alle behandeldagen gemeten, en daarna na zes weken, en 3, 6, 9 en 12 maanden na randomisatie. Daarnaast wordt door de arts aan het begin van de behandelingen en na zes weken bepaald hoe de stabiliteit en functionaliteit van de enkel is.

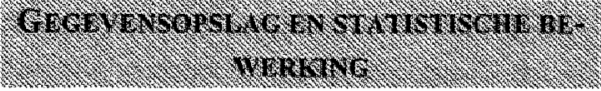

Alle uit het onderzoek verkregen gegevens worden anoniem verwerkt en opgeslagen in dBASE IV. De data zijn gecontroleerd op volledigheid, inconsistenties en protocolafwijkingen. Vervolgens worden de data geanalyseerd met het statistische pakket SPSSWIN/PC. De analyse geschiedt door middel van het intention-to-treat principe: alle deelnemers, inclusief diegenen met slechte compliance en uitvallers, blijven tijdens de analyse in de groep waartoe zij gerandomiseerd zijn. De data analist was gedurende de analyses niet op de hoogte van de doseringen die de drie onderzoeksgroepen hebben gehad. De verschillen in primaire en secundaire uitkomstmaten tussen de drie groepen worden met ANOVA (tweezijdig) geanalyseerd. Een nadere analyse in subgroepen (leeftijd, sportdeelname, soort werk) wordt uitgevoerd om te kijken of deze factoren van invloed zijn op het herstel. Pas na volledige analyse wordt de blindering doorbroken.

Verschillen tussen de groepen op de lange termijn worden eveneens met ANOVA (tweezijdig) geanalyseerd, of in geval van dichotome variabelen wordt met behulp van een Cox regressiemodel gerekend, terwijl verschillen in sporthervatting tussen de groepen met een Kruskal-Wallis test voor niet normaal verdeelde data wordt berekend.

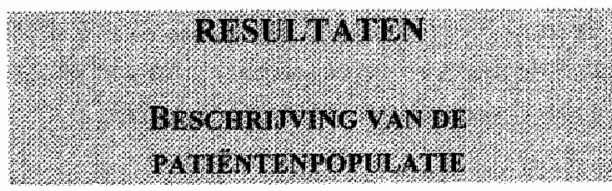

Van 1 September 1993 tot 31 December 1995 zijn 217 patiënten gerandomiseerd. Van alle patiënten zijn baseline gegevens verkregen. 
Van de 2064 behandelingen ( $217 \times 12)$ zijn er slechts 43 gemist. De uitval kwam voor $0.4 \%$ voor rekening van de groep met de lage laser dosering, $0.7 \%$ van de groep met de hoge laser dosering en $1 \%$ van de placebo groep.

De 1 jaars follow-up is uiteindelijk door 18 patiënten gemist; 6 in de groep met de lage laser dosering $(\mathrm{L})$ groep, 4 van de groep met de hoge laser dosering $(\mathrm{H})$ groep en 8 van de placebo groep (P). Deze waren telefonisch of schriftelijk onbereikbaar, verhuisd of reageerden niet. In tabel 6 staan de baseline gegevens van de drie groepen.

Tabel 6: Baseline gegevens van de onderzoekspopulatie

\begin{tabular}{|c|c|c|c|c|c|c|}
\hline & \multicolumn{2}{|c|}{ 15is } & \multicolumn{2}{|c|}{ 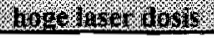 } & 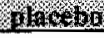 & \\
\hline antal oalienten & 74 & & 72 & & 71 & \\
\hline geviddelde leefijc (sd) & 30,2 & $(9,6)$ & 33,2 & $(10,4)$ & 30,9 & $(10,3)$ \\
\hline geslacht (rroww/nan) & $30 / 44$ & & $17 / 55$ & & $22 / 49$ & \\
\hline baseline netingen & & & & & & \\
\hline gemiddelde functe score (sa) & 13,1 & $(10,6)$ & 12,1 & $(10,8)$ & 13,4 & $(11,8)$ \\
\hline geniddelde pin overdag (sd) & 3,7 & $(2,7)$ & 3,8 & $(2,5)$ & 3,6 & $(2,8)$ \\
\hline geniddelde pij s ochitends (sd) & 4,8 & $(2,9)$ & 4,4 & $(2,9)$ & 4,2 & $(3,0)$ \\
\hline geniddeld aanital pinstillers ( $\mathrm{sd}$ ) & 0,5 & $(1,0)$ & 0,8 & $(\mathbb{1}, 4)$ & 0,7 & $(1,4)$ \\
\hline sermiddelde drukpinn in kg/cm (sd) & & & & & & \\
\hline lig calcaineo fibulare & 3,2 & $(1,9)$ & 3,3 & $(1,9)$ & 3,5 & $(1,9)$ \\
\hline Iig talofibulare anterius & 1,7 & $(1,3)$ & 1,8 & $(1,4)$ & 1,6 & $(1,0)$ \\
\hline Iig tailofibulare posterius & 3,6 & $(2,0)$ & 3,1 & $(2,0)$ & 3,3 & $(1,8)$ \\
\hline Bemiddelde sport categ orle & 2,2 & $(0,8)$ & 2,1 & $(0,8)$ & 2,1 & $(0,8)$ \\
\hline gemiddelde piognose ontrent hetste & & & & & & \\
\hline na wee weken & 7,2 & $(1,2)$ & 6,9 & $(1,2)$ & 7,4 & $(1,2)$ \\
\hline na Wier weken & 9,4 & $(0,8)$ & 9,2 & $(0,8)$ & 9,4 & $(0,9)$ \\
\hline
\end{tabular}

Hemeten op eeri 100 punts functie schaal

* gemeten op een rapportcijfer schaal ( 0 is geen pijn, 10 is uiterst pijnlijk)

- geneten op een 4-punts schaal ( 0 is geen sport 1 recreatief, 2 competitie, 3 professioneel)

¿ gemeten op een rappontcijfer schaal ( 0 is niet hersteld, 10 is volledig hersteld)

De groepen zijn op baseline niveau goed vergelijkbaar. Alleen de gemiddelde leeftijd van de hoge laser dosering groep is iets hoger dan van de andere twee groepen en de verhouding tussen mannen en vrouwen verschilt.
Bij verdere verdeling van de groepen naar type werkzaamheden of zwaarte van de verrichte arbeid zijn geen opmerkelijke verschillen te constateren (zie tabel 7). 
Tabel 7: Indeling naar type en zwaarte van de arbeid

\begin{tabular}{|c|c|c|c|c|}
\hline & & 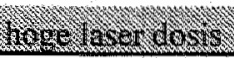 & (1) & 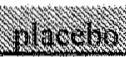 \\
\hline blue white collar & & $37 / 30(5)^{*}$ & $37 / 35(2)$ & $35 / 32(4)$ \\
\hline \multirow{4}{*}{ arbeid } & licht & 17 & 21 & 20 \\
\hline & normaal & 18 & 19 & 19 \\
\hline & zwaar & 30 & 28 & 27 \\
\hline & erg zwaar & 7 & 6 & 5 \\
\hline
\end{tabular}

* tussen haakjes staan de aantallen personen die aangeven niet te werken; huisvrouwen en studerenden zijn als respectievelijk blue en white collar werkenden aangemerkt

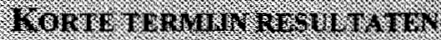

Tabel 8 laat de resultaten zien van de primaire en secundaire effectmaten, gedurende de behandelperiode en de afsluiting daarvan (eerste vier weken).

Op 10 en 14 dagen na het trauma treden de grootste verschillen op tussen de groepen. Er zijn geen significante verschillen waarneembaar in ervaren pijn, drukpijn en zwellingsafname. De uitkomstmaten functie en $A D L$ beperking laten de grootste verschillen tussen de groepen zien op 10 en 14 dagen: met de placebogroep gaat het hier significant beter. Ook qua werkhervatting presteert de placebogroep significant het best: vergeleken met de lasergroepen zijn patiënten in de placebogroep 3,4 tot 4,7 dagen eerder aan het werk. Het verschil in dagen tot sporthervatting is gering. Het subjectief ervaren herstel, een samenvattende waarderingsmaat van de patiënt, laat een klein voordeel zien voor de placebogroep ten opzichte van de twee lasergroepen. 
Tabel 8: Uitkomsten (gemiddelden en sd) gedurende de eerste vier weken van het onderzoek en p-waarden van de verschillen (geanalyseerd m.b.v. ANOVA)

\begin{tabular}{|c|c|c|c|c|c|}
\hline 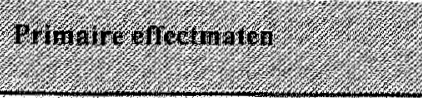 & & 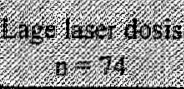 & 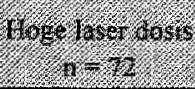 & 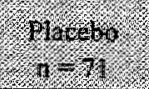 & (t) \\
\hline Eryaren 1 in (gen, sd)d) & datg 5 & $2,8 \quad(2,2)$ & $2,9 \quad(2,1)$ & $3,3(2,4)$ & 0,6 \\
\hline & dag 10 & $2,0 \quad(2,0)$ & $2,1 \quad(1,9)$ & $1,7(1,9)$ & 0,48 \\
\hline & $\operatorname{dag} 14$ & $1,6(1,9)$ & $1,7 \quad(1,7)$ & $1,4(1,7)$ & 0,42 \\
\hline & dag 28 & $0,6(1,0)$ & $0,8 \quad(1,2)$ & $0,4(1,0)$ & 0,14 \\
\hline Functie score (gen, sd) & dag 5 & $25,1(15,0)$ & $24_{*} 7(15,1)$ & $25,7(14,8)$ & 0,92 \\
\hline & dag 10 & $42,2(16,1)$ & $44,1(14,9)$ & $49,9(15,9)$ & 0,01 \\
\hline & dag 14 & $56,3(16,1)$ & $56,0(15,7)$ & $60,0(17,1)$ & 0,03 \\
\hline & $\operatorname{dag} 28$ & $73,6(14,7)$ & $74,3(17,5)$ & $76,4(14,9)$ & 0,5 \\
\hline \multicolumn{6}{|l|}{ Secundaire e freetmaten } \\
\hline Werkhervatting in dagen (gen, sd) & & $12,5(11,1)$ & $11,2(10,0)$ & $7,8(9,2)$ & 0,02 \\
\hline Sporthervating n dagen (gem, sd) & & $27,3(7,9)$ & $27,4(7,5)$ & $25,3(9,8)$ & 0,26 \\
\hline & & $(2,6)$ & $(2,8)$ & $(2,7)$ & \\
\hline Alou beperking (gern, s) Q & $\operatorname{dag} 5$ & $4,4(2,7)$ & $4,9(2,4)$ & $4,8(2,2)$ & 0,42 \\
\hline & dag 10 & $3,7(2,6)$ & $3,3 \quad(2,1)$ & $2,6(2,1)$ & 0,03 \\
\hline & dag 14 & $2,8(1,5)$ & $2,7 \quad(1,5)$ & $2,0(1,6)$ & 0,08 \\
\hline & dag 28 & 0,9 & 1,0 & 0,8 & 0,83 \\
\hline \multirow{2}{*}{ 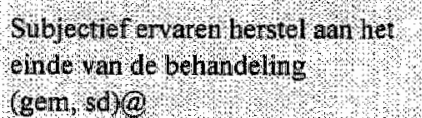 } & & $(0,9)$ & $(0,9)$ & $(0,8)$ & \\
\hline & & 8,6 & 8,7 & 8,9 & 0,05 \\
\hline
\end{tabular}

(a) Gemeten op een rapportcijfer schaal (niet beperkt 0 , viterst beperkt 10)

* Gemeten op een 100 punts schaal ( 0 is uiterst beperkt, 100 uitstekende functie)

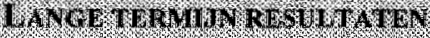

In tabel 9 staan de resultaten zoals gemeten gedurende de lange termijn follow-up. Ook na zes weken blijft het opmerkelijke verschil in werkhervatting bestaan: het verschil is zelfs iets groter dan bij 4 weken.
Kortom, de placebogroep vertoont het meeste herstel. Bij sportverzuim is een verschil van ongeveer 7 dagen te zien, waarbij de placebogroep het snelst weer aan het sporten is. De andere uitkomstmaten laten geen significante verschillen zien op 3,6,9 en 12 maanden na letsel. 
Tabel 9: Lange termijn resultaten

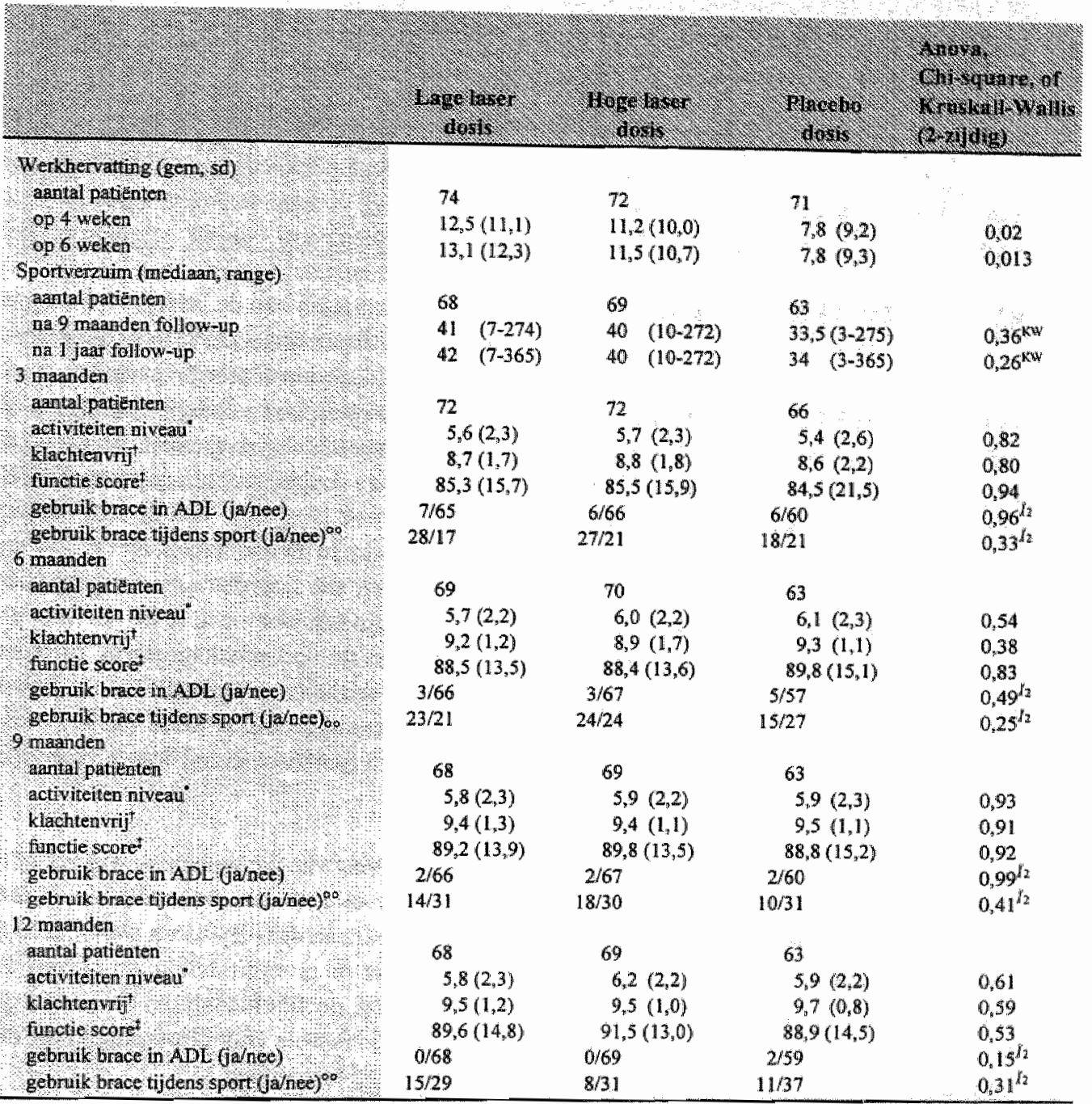

* gemeten op een $0-10$ punten schaal

+ gerneten op een $0-10$ punten schaal ( 10 is klachtenviij)

* gemeten op een $0-100$ punten schaal ( 0 is geen functie, 100 perfecte functie)

ob alleen van toepassing op sporters

Tabel 10 tenslotte laat het aantal recidieven per drie maanden zien. Het cumulatieve aantal recidieven na 1 jaar verschilt significant tussen de drie groepen. De groep met een lage dosis laser laat de meeste recidieven zien. 
Tabel 10: Aantallen recidieven per drie maanden

\begin{tabular}{|c|c|c|c|c|c|c|c|c|c|}
\hline 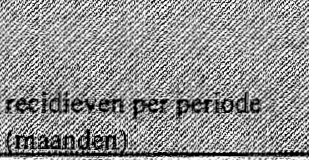 & & & 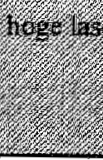 & 8 & & & $19+1$. & & 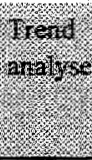 \\
\hline 3 maanids recidieven / 1 : & $11 / 72$ & & $6 / 72$ & & $5 / 66$ & & $22 / 210$ & 0,26 & 0,18 \\
\hline 6 niandis recidieven $\mathrm{N}$ & $7 / 69$ & 18 & $2 / 70$ & 8 & $4 / 63$ & 9 & $13 / 202$ & 0,22 & 0,08 \\
\hline 9 niaands recidleven $/ \mathrm{N}$ & $4 / 68$ & 22 & $2 / 69$ & 10 & $1 / 62$ & 10 & $7 / 199$ & 0,39 & 0,346 \\
\hline 12 maands reedick on / 1 & $0 / 68$ & 22 & $3 / 69$ & 13 & $0 / 62$ & 10 & $3 / 199$ & 0,04 & 0,037 \\
\hline
\end{tabular}

\section{D.18. 1.51}

De effectiviteit van laser therapie wordt meestal bestudeerd op basis van korte termijn resultaten. Dit komt mede omdat de meeste auteurs geïnteresseerd zijn in de korte termijn effecten zoals pijn-en zwellingsvermindering. Dit onderzoek laat zien dat lasertherapie ook op de middellange en lange termijn ( 1 jaar) interessante bevindingen oplevert. Het is opvallend dat zowel op de korte als de lange termijn de placebogroep beter presteert qua werkverzuim en sporthervatting. Op de korte termijn zijn ook functiescore en $A D L$ beperking op bepaalde momenten significant in het vootdeel van de placebogroep, terwijl de lange termijn laat zien dat het aantal recidieven bij de placebogroep significant het geringst is. Hierbij dient aangetekend te worden dat het aantal recidieven in de lage doseringsgroep het grootst is en daarmee verantwoordelijk is voor het significante verschil tussen de groepen. Het aantal recidieven in dit onderzoek is vergelijkbaar met dat van andere onderzoeken. Toch is niet te verklaren waarom de groep met de laagste dosering de meeste recidieven laat zien.

Als we het gemiddelde werkverzuim veroorzaakt door enkelbandletsels in Nederland (7.3 dagen) vergelijken met dat van de placebogroep (7.8) dagen, dan zijn deze redelijk tot goed vergelijkbaar.
Het werkverzuim van de lasergroepen is gemiddeld 4 dagen langer; deze zijn waarschijnlijk grotendeels toe te schrijven aan het negatieve effect van laser. Subgroepanalyses op type werkzaamheden en zwaarte van het werk lieten tussen de drie groepen geen verschillen zien (zie ook tabel 3b). Van de 2283 dagen werkverzuim in dit onderzoek, zijn er 590 toe te schrijven aan lasertherapie. De gevonden effecten zijn ook niet toe te schrijven aan verschillen in de onderzoeksgroepen. Immers, baseline variabelen, prognostische variabelen, type werkzaamheden, zwaarte van het werk, niveau van sportbeoefening waren vergelijkbaar.

De blindering van dit onderzoek was volledig en succesvol. Patiënten, behandelaars, effectbeoordelaars en data-analisten waren geblindeerd voor de groepsindeling, en bleven dat ook tot na de hoofdanalyses waren uitgevoerd. Bij controle voor blindering bleek deze geslaagd te noemen.

Helaas moeten we, gezien het bovenstaande concluderen, dat lasertherapie niet de gewenste of verwachte effecten sorteert bij de behandeling van enkelbandletsels, die men in het algemeen verwacht had. Op basis van deze bevindingen lijkt het dan ook verstandig $904 \mathrm{~nm}$ laser niet meer te gebruiken bij de behandeling van enkelbandletsels. 


\section{EIGBX WENRG}

Tenslotte kan de lezer zich afvragen of de vragen die gesteld werden aan het begin van dit proefschrift afdoende beantwoord zijn. De verrichte reviews laten zien dat er nog veel onzekerheid bestaat over effectieve interventies bij acute enkelbandlletsels. Tevens is de effectiviteit van $904 \mathrm{~nm}$ lasertherapie niet aan te tonen bij aandoeningen van het bewegingsapparaat.

Dit proefschrift laat zien dat een goede inschatting van het beloop van een acuut enkelbandletsel direct na trauma goed mogelijk is, maar dat nader onderzoek het ontwikkelde instrument moet bekrachtigen.
Aangaande de effectiviteit wan $904 \mathrm{~nm}$ laser therapie kan gesteld woorden dat het hier verrichte onderzoek duidelijk aangeeft dat toepassing ervan bij laterale enkelbandletsels geen zin heeft. In hoeverre dit ook voor andere, vergelijkbare aandoeningen van het bewegingsapparaat geldt dient nader uitgezocht te worden. Het is mogelijk dat bij andere indicatiegebieden laser wel effectief is, temeer daar ons experiment laat zien dat er een interactie bestaat tussen bestraald weefsel en laser. Het gevonden vertraagde herstel gedurende de acute ontstekingsfase zou voor patiënten met een chronische ontsteking (bijv. reuma) gunstig kunnen zijn; immers demping van de ontsteking zou in die gevallen een vermindering van gewrichtsbeschadiging en vermindering van klachten kunnen impliceren. Nader onderzoek dient hierover uitsluitsel te geven. 


\section{OAN woora}

In het najaar van $1991 \mathrm{kwam}$ ik op uitnodiging van Frans van den Wildenberg eens praten bij de vakgroep algemene heelkunde van het azM over het opzetten van een grote studie naar de effectiviteit van laag vermogen lasertherapie bij laterale enkelbandletsels. We konden elkaar al snel vinden en onder het genot van sloten koffie en met veel plezier werd al snel een eerste voorstel gelanceerd. Lex Bouter hielp in die fase letterlijk van onder de kerstboom mee met schrijven. Na enige traumatische arvaringen in subsidieland werd het laserproject alsnog in 1993 gefinancierd. Het profileringsfonds, Uniphy bv, NEA international en de vakgroep epidemiologie van de UM stonden garant voor de financiering van het project. In de herfst van dat jaar kon er worden gestart. Nu, ruim vier jaar later, ligt het eindproduct voor $u$.

Natuurlijk is een dankwoord er om mensen te bedanken, maar ook om te laten zien dat je mensen waardeert. Niet alleen in het kader van dit promotieonderzoek, maar ook daarbuiten.

Riekje de Vet is, mits ze de trein, boot of het vliegtuig haalt, iemand waar je altijd van op aan kunt. $\mathrm{Ze}$ heeft een plezierige stijl van leiding geven en je komt altijd weer met een goed advies bij haar vandaan. Als co-promotor van dit proefschrift en deze promovendus, die ze min of meer in de schoot geworpen kreeg, heeft ze veel meegedacht en geschreven. Ook heeft ze laten zien dat de overgang van voeding naar bewegingsapparaat een goede keuze was. Met veel plezier denk ik ook terug aan de vele reizen die we samen maakten en de dwaze avonturen die we dan beleven in onderzoeksland. Ik hoop nog lang samen met je de wereld van het onderzoek op het terrein van het bewegingsapparaat en de meta-amalyse onveilig te maken.

Frans van den Wildenberg is begeleider van het eerste uur. Van achter zijn onafscheidelijke pijp kijken je altijd twee pretogen tegemoet, en voor een inhoudelijke en gezellige discussie gaat hij nooit uit de weg. Ik wil hem bedanken voor zijn geweldige inzet tijdens de praktische periode van het onderzoek.s en zijn onstuitbare optimisme en enthousiasme in de begeleiding. Samen met Frans huldig ik het standpunt dat de smakelijkste discussies in het restaurant plaats vinden.

Ton Lenssen is als onderzoeksassistent de spil in het laseronderzoek geweest. Zonder zijn inzet en motivatie, maar ook zijn relativerende opmerkingen en actieve meedenken, was dit onderzoek nooit zo goed uit de verf gekomen. Ook denk ik met veel plezier terug aan alle "randverschijnselen' die we samen hebben beleefd, en de vele autoritten van en naar bijeenkomsten in den lande, waar we over het wel en wee van de fysiotherapie hebben gefilosofeerd. Ik ben dan ook heel blij dat je mijn paranimf wil zijn.

Maria Kerckhoffs, Nynke Smit, Margreet te Giffel en Jolanda Luime hebben als back-up team en weekend behandelaars geweldig veel werk verzet. Zonder hun gemotiveerde inzet waren er vast veel patiënten geweest die op zon- en feestdagen waren thuisgebleven of niet zo trouw hun huiswerkoefeningen hadden gedaan. Ook door de patiènten werd hun 
grote inzet bij nachi en ontij zeer gewaardeerd.

De afdeling fysiotherapie wil ik bedanken voor de grote gastvrijheid en de collegialiteit tijdens de praktische uitvoering van het onderzoek, maar ook voor de voortdurende prettige samenwerking (nu en in de toekomst). In het bijzonder heb ik waardering voor de levering van extra patiënten aan het onderzoek (Ton en Eddie) als de instroom wat slapjes was.

Alle artsen en arts-assistenten van de afdeling algemene heelkunde hebben zich geweldig ingespannen om de instroom van dit onderzoek te laten slagen, en om de zes weken metingen vloeiend te laten verlopen. Natuurlijk wil ik ook de verpleegkundigen van de acute opvang en de poli alsmede de verbandmeesters van het azM van harte bedanken voor hun inzet en oplossingen tijdens het onderzoek. Altijd waren zij bereid tot improvisatie en advies. De dames van de balie vormden de smeerolie van het onderzoek. Zij vingen dolende patiènten op en verwezen nieuwe patiënten naar de juiste behandelaars.

Mijn beide promotoren, Gauke Kootstra en Paul Knipschild, wil ik bedanken voor het in mij gestelde vertrouwen, en de bewaking van de voortgang. Paul heeft mij geleerd in de contramine te gaan terwijl Gauke liet zien dat we met $z$ ' $n$ allen 'buitengewoon aardig' bezig waren.

Arianne Verhagen is mijn andere paranimf, één van de eerste studenten van eigen kweek en mijn eerste AIO die ik samen met Riekie begeleid. Arianne, al jaren ben je met jouw no-nonsense benadering een mooie sparringspartner op onderzoeksgebied, en ik hoop dat we samen nog vele 'stukjes over de fysiotherapie" produceren. Bovendien weet je de weg in Amsterdam, wat voor een jongen uit de provincie mooi meegenomen is.

Cobie Martens verdient eigenlijk een hele pagina in het dankwoord, maar angezien het aantal katernen in een proefschrift kritisch is (zoals je mij hebt uitgelegd) volsta ik ermee je hierbij van harte te bedanken voor de vele uren typen en layout werk ten behoeve van dit proefschrift.

Jos Slangen, Fons Kessels en Harry van Montfort wil ik graag bedanken voor de ondersteuning op het gebied van dataanalyse en data-bases. Voor de toekomst weten we nu dat alles te analyseren is, zolang er maar geen komma's in zitten en niemand last heeft van kleurenblindheid.

Een bijzonder woord van dank verdienen mijn 'buurvrouwen' Jolanda, Elizabeth en Anne-Marie. Ze staan altijd klaar met thee (en soms een koekje), verzorgen de plantjes als ik weg ben en hebben altijd tijd voor een praatje of een maandagochtendmop.

Mijn collega's op de vakgroep wil ik bedanken voor de gezellige werksfeer en de goede samenwerking. In het bijzonder Sandra (ik fiets weer!), Gerben (buena diminaza, domnul Ter Riet; kan ik u even spreken over een moeilijk methodologisch probleem), Erik (ik heb die onderwijsprijs nu toch zeker wel verdiend), Martien (de vraagbaak op epidemiologie gebied, misschien dankzij Gingko? of ondanks agenda), Miranda (ik heb nog een klusje), 
Matty (stel nog eens een vraag), Gerard (kom je praten over de verbouwing jongen) en Raymond (onze Sherlock Holmes en het mysterie van 'his first Sony").

Mijn collega-onderzoekers op het EMGOinstituut, onder aanvoering van chief Lex Bouter (van wie ik veel heb geleerd en met wie het prettig samenwerken en reizen is), will ik bedanken voor de gezellige (al dan niet wetenschappelijke) contacten. Lex, Bart, Pim, Daniëlle, Maurits en Rob, bedankt!

De collega's van de Hogeschool Heerlen (Jo, Piet, Fredy en de sectie fysische therapie) wil ik bedanken voor de altijd (en inmiddels al vele jaren) plezierige contacten en samenwerking.
Pieter Wolters wil ik in het bijzonder bedanken voor de prettige en kameraadschappelijke samenwerking. Helaas zijn nu je uren op, maar ik denk (en hoop) je nog meer te zien dan vroeger.

Hannerieke, mijn partner, deelt natuurlijk in de feestvreugde en kan alvast zien hoe dit allemaal verloopt; immers over enkele jaren is ze zelf aan de beurt. Zonder haar liefde en inzet, opgewekte karakter en levenslust was deze wetenschapper vast niet zo ver gekomen. Thuiskomen na het werk of studiereis is een feest!

Rob de Bie, Januari 1998 
RA de Bie, MA, Pt. Department of Epidemiology, University Maastricht

LM Bouter, PhD. EMGO-institute, Free University of Amsterdam

G Kootstra, PhD, MD. Department of General Surgery, University Hospital of Maastricht

PG Knipschild PhD, MD. Department of Epidemiology, University Maastricht

AF Lenssen, Pt. Department of Physiotherapy, University Hospital of Maastricht

AP Verhagen. Msc, Pt. Department of Epidemiology, University Maastricht

HCW de Vet, PhD. Department of Epidemiology, University Maastricht

FAJM van den Wildenberg, PhD, MD. Department of General Surgery, University Hospital of Maastricht
Bie RA de, Verhagen AP, Lenssen AF, Vet HCW de, Wildenberg FAJM, Kootstra G, Knipschild PG. Efficacy of conservative interventions in the treatment of acute lateral ankle sprains: a systematic review. (submitted)

Bie RA de, Verhagen AP, Lenssen AF, Vet HCW de, Wildenberg FAJM, Kootstra G, Knipschild PG. Efficacy of $904 \mathrm{~nm}$ laser therapy in musculoskeletal disorders: a systematic review. Physical Therapy Reviews (accepted).

Bie RA de, Vet HCW de, Wildenberg FAJM, Lenssen AF, Knipschild PG. The prognosis of ankle sprains. International Journal of Sports Medicine 1997; 18(4): 285-9.

Bie RA de, Vet HCW de, Wildenberg FAJM, Lenssen AF, Bouter LM, Knipschild $P G$. Efficacy of laser therapy in ankle sprains: design of a randomised clinical trial. Laser therapy 1997; 9: 165-72.

Bie RA de, Vet HCW de, Lenssen AF, Wildenberg FAJM, Kootstra G, Knipschild PG. Efficacy of low level laser therapy in ankle sprains: short term results of a randomised clinical trial. Archives of Physical Medicine and Rehabilitation (accepted).

Bie RA de, Vet HCW de, Lenssen AF, Wildenberg FAJM, Kootstra G, Knipschild $P G$. Efficacy of low level laser therapy in ankle sprains: one year results of a randomised clinical trial. Archives of Physical Medicine and Rehabilitation (accepted). 
Rob de Bie werd geboren op 27 augustus 1963 te Onstwedde, Groningen. $\mathrm{Na}$ het behallen van het Atheneum-B diploma aan de Thorbecke Scholengemeenschap te Zwolle in juni 1983, studeerde hij fysiotherapie aan de Deventer Academie voor Fysiotherapie. Na het behalen van het diploma fysiotherapie in juli 1987, studeerde hij tot juni 1991 Bewegingswetenschappen aan de Rijksuniversiteit Limburg, met als keuzevakken epidemiologie en docententraining. Hij studeerde af op de effectiviteit van laag frequent magneetveldtherapie.

Daarna werd hij als toegevoegd docent bij de vakgroep epidemiologie aangesteld met als taakopdracht het ontwikkelen van een onderzoekersopleiding voor fysiotherapeuten. In februari $1992 \mathrm{kreeg}$ hij bij de vakgroep
Epidemiologie een vaste aanstelling als universitair docent, met als taakopdracht het verzorgen van epiderniologie onderwijs binnen de Faculteit der Gezondheidswetenschappen en het verrichten van onderzoek binnen het onderzoeksinstituut Extra, op het terrein van het bewegingsapparaat. Van 1987 tot 1992 is hij tevens werkzaam geweest als fysiotherapeut in praktijk woor fysiotherapie Mays te Maastricht.

Rob volgde cursussen bij Bouter, Kleinbaum, Miettinen, Rothman en Sackett.

Tevens is Rob editor voor de Cochane Back Group, de Cochrane Musculoskeletal Group en het tijdschrift Physical Therapy Reviews. Samen met Riekie de Vet coördineert hij het Cochrane Rehabilitation and Related Therapies Field. 